\title{
O POSICIONAMENTO DA INDÚSTRIA AVÍCOLA FRENTE ÀS RESTRIÇÕES DO MERCADO CONSUMIDOR EUROPEU
}

\author{
ANDRÉA CRISTINA DÖRR \\ Bacharel em Ciências Econômicas
}

Orientador: Prof. Dr. PEDRO VALENTIM MARQUES

Dissertação apresentada à Escola Superior de Agricultura "Luiz de Queiroz", Universidade de São Paulo, para obtenção do título de Mestre em Ciências, Área de Concentração: Economia Aplicada.

P I R A C I C A B A

Estado de São Paulo - Brasil

Novembro -2003 


\section{Dados Internacionais de Catalogação na Publicação (CIP) DIVISÃO DE BIBLIOTECA E DOCUMENTAÇÃO - ESALQ/USP}

\section{Dörr, Andréa Cristina}

O posicionamento da indústria avícola frente às restriçōes do mercado consumidor europeu / Andréa Cristina Dörr. - - Piracicaba, 2003.

145 p. 2003.

Dissertação (mestrado) - - Escola Superior de Agricultura Luiz de Queiroz, Bibliografia.

1. Análise de risco 2. Avicultura 3. Exportação 4. Indústria agrícola 5. Segurança alimentar 6. União Européia 7. Qualidade dos alimentos 1. Título

CDD 338.1765 
Dedico este trabalho

à minha família, pelo seu amor e constante incentivo,

fonte de inspiração e força

para abraçar os desafios.

Dedico às minhas amigas de verdade:

Liliana Arenhardt

Liane Beutler

Scheila Fenner

Lindamir Adamczuk

Luciane Schneider

por acreditarem em mim.

Samanta e Jonathan, com carinho. 


\section{AGRADECIMENTOS}

Meus sinceros agradecimentos às pessoas e instituições que tornaram possível a realização deste trabalho:

À Fundação de Amparo à Pesquisa do Estado de São Paulo (FAPESP) pela concessão de auxílio financeiro para a execução do projeto;

Ao Prof. Dr. Pedro V. Marques pela orientação e amizade durante todo o curso;

Aos Profs. Dra. Márcia Azanha Dias de Moraes, Alexandre L. Mendonça de Barros e Sílvia Helena Galvão de Miranda pela contribuição a este trabalho;

Às pessoas de Maria Aparecida Maielli Travalini, Cristiane Cipriano, Helena Aparecida Cardoso, Márcia Maria Beltrame, Ligiana Clemente e Álvaro Sobreiro Filho pelo apoio técnico e paciência;

Aos colegas e hoje amigos do Programa de Educação Continuada em Economia e Gestão de Empresas (PECEGE), Diogo S. Dragone e Milene Maganhato;

À Escola Superior de Agricultura Luiz de Queiroz, pela oportunidade de realização do curso de mestrado;

Aos colegas e amigos deste Departamento pela amizade;

À especial pela amizade e companhia. 


\section{SUMÁRIO}

Página

LISTA DE QUADROS...................................................................................... vii

LISTA DE TABELAS ...................................................................................... ix

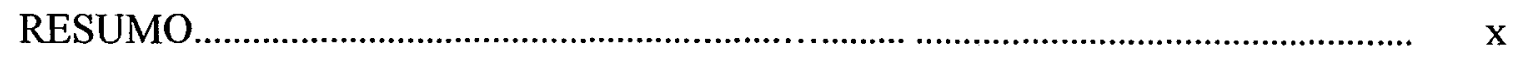

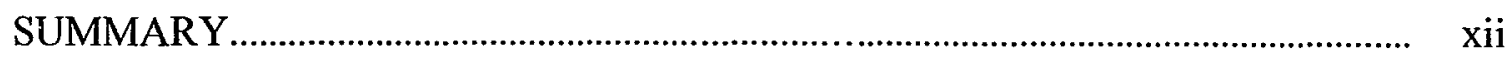

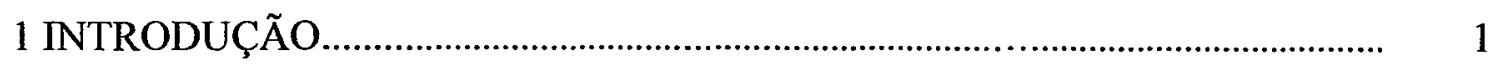

1.1 Objetivos e hipótese..................................................................................... 3

1.2 Estrutura de apresentação.................................................................................. 3

2 REVISÃO DE LITERATURA.................................................................. 5

2.1 Estrutura organizacional da União Européia................................................... 5

2.2 Panorama da avicultura no Brasil....................................................................... 6

2.3 Estabelecimentos europeus............................................................................. 14

2.4 Principais problemas de contaminação............................................................. 15

2.5 Preocupações da União Européia com o consumidor............................................ 17

2.6 Segurança do alimento e certificação.................................................................. 19

2.7 Controles da qualidade................................................................................... 22

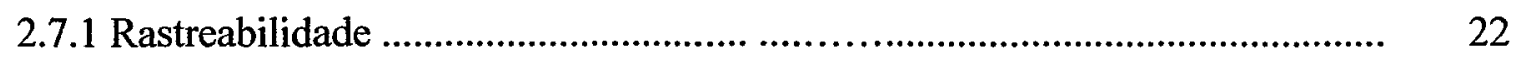

2.7.2 Boas Práticas de Fabricação (BPF) ………….............................................. 25

2.7.3 Análise de Riscos e Pontos Críticos de Controle (HACCP).............................. 26

2.7.4 Sistema Europeu de Inspeção e Segurança do Alimento (EFSIS) e Internacional Standartization Organization (ISO)......................................... 27

2.8 Principais alterações institucionais européias..................................................... 28

2.8.1 Ingredientes de origem animal.................................................................... 28

2.8.2 Grãos geneticamente modificados................................................................. 31

2.8.3 Antibióticos ................................................................................................. 34 


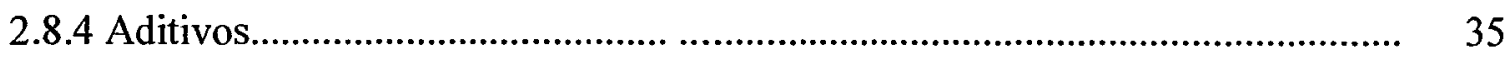

3 REFERENCIAL TEÓRICO........................................................... 36

3.1 Nova Economia Institucional........................................................... 36

3.1.1. Economia dos custos de transação................................................................ 37

3.1.1.1 Pressupostos comportamentais.................................................. 37

3.1.1.1.1 Ativos específicos.................................................................... 38

3.1.1.1.2 Frequência..................................................................... 39

3.1.1.1.3 Incerteza........................................................................ 41

3.2 Ambiente institucional ............................................................ 42

3.3 Integração vertical ............................................................................ 44

3.4 Contratos na avicultura .............................................................. 46

3.5 Estudos de caso........................................................................... 48

4 MATERIAL E MÉTODOS................................................................ 49

4.1 Obtenção dos dados ............................................................................ 50

4.2 Definição das variáveis....................................................................... 51

4.2.1 Variáveis do questionário.............................................................. 52

4.2.1.1 Produção...................................................................................... 52

4.2.1.2 Relacionamento da empresa com os clientes europeus................................. 53

4.2.1.3 Relacionamento da empresa com os fornecedores de matéria-prima............. 54

4.2.1.4 Relacionamento da empresa com os fornecedores de premix........................ 55

4.2.2. Variáveis dos estudos de caso....................................................... 55

4.2.2.1 Produção.................................................................................. 55

4.2.2.2 Relacionamento da empresa com clientes europeus......................... 56

4.2.2.3 Relacionamento da empresa com fornecedores de matéria-prima................. 58

4.2.2.4 Relacionamento da empresa com fornecedores de premix........................... 58

4.3 Análise dos dados.......................................................................................... 59

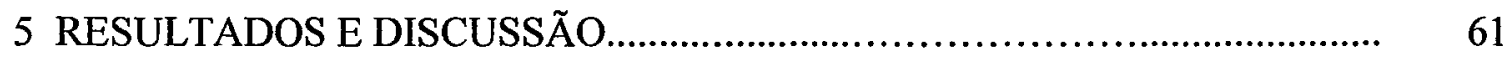

5.1 Esclarecimentos iniciais................................................................................... 61 
5.1.1. Problemas intrínsecos à pesquisa via questionários........................................ 61

5.2 Produção e exportação..................................................................................... 62

5.3 Preocupação em relação à segurança do alimento................................................ 62

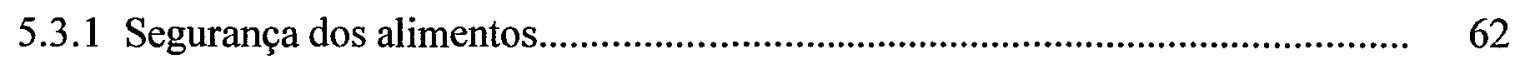

5.3.2 Países dos clientes europeus......................................................................... 63

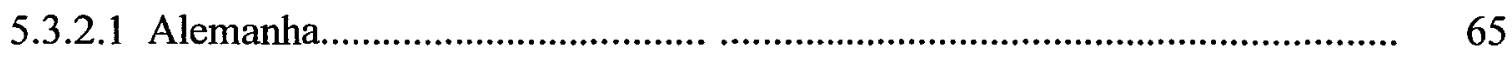

5.3.2.2 Holanda

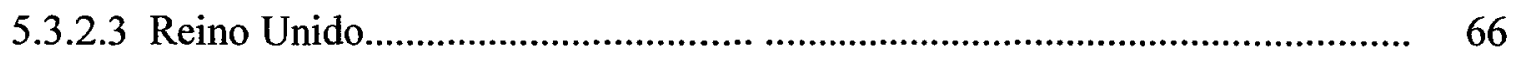

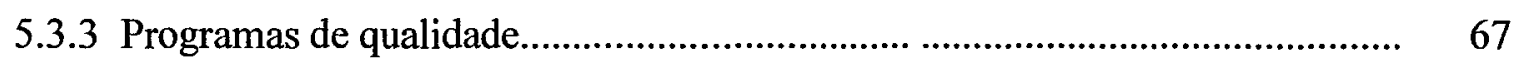

5.3.4 Exigências dos clientes europeus em relação à matéria-prima......................... 70

5.3.5 Opinião da empresa............................................................................. 72

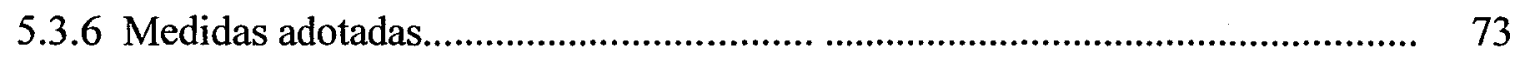

5.3.7 Demandas feitas ao atuação do setor público.................................................. 75

5.4 Fornecedores de matéria-prima............................................................................ 76

5.4.1 Matéria-prima frango................................................................................ 76

5.4.2 Relacionamento com o seu fornecedor de grãos................................................. 77

5.4.3 Relacionamento com o fornecedor de premix.................................................... 78

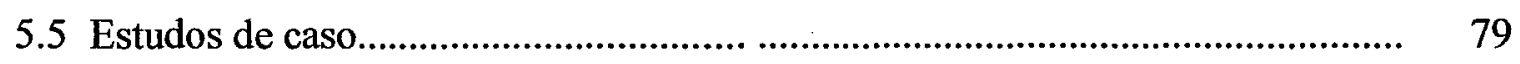

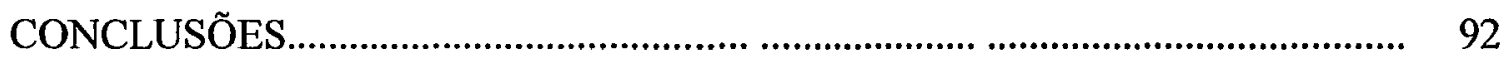

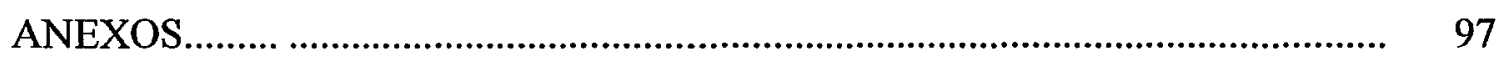

REFERÊNCIAS BIBLIOGRÁFICAS....................................... 113

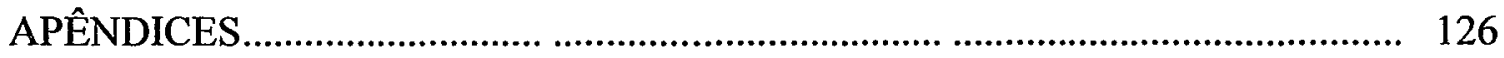




\section{LISTA DE QUADROS}

Página

1 Relação entre comportamento dos indivíduos, especificidade dos ativos e tipo de contrato esperado. 40

2 Desde quando a empresa exporta para a União Européia? 80

3 Qual a ordem de importância da UE na lista dos clientes? 80

4 Por que a empresa optou para exportar para este mercado? 80

5 A produção exportada para a UE no período de 1996-2002 em US\$.

6 Explique a função do cliente europeu com o qual sua empresa trabalha (processador, distribuidor, trader):

7 Desde quando o cliente passou a exigir que a empresa implantasse programas de qualidade?

8 Desde quando implantou o Programa EFSIS? Se não implantou, ainda não foi exigido?

9 Como é o sistema de rastreabilidade implantado? (por lote, por origem, por data de abate, por tipo de destino de cliente, etc.).

10 Além das exigências (GGM; subprodutos de origem animal; aditivos, antibióticos; promotores de crescimento) existem outras que os clientes europeus passarão a exigir em breve?

11 Em relação às medidas que a empresa adotou para atender os clientes, elas foram adotadas somente para atender a solicitação dos clientes europeus ou também para atender outros clientes?

12. Existem outras medidas importantes que a empresa adotou para satisfazer os clientes no que diz respeito à segurança dos alimentos fabricados?......

$13 \mathrm{~A}$ análise das especificidades do frango (inteiro e em cortes) exportado é realizada na UE? A empresa acha que esta análise deveria ser feito no Brasil, 
sob a supervisão do MAPA ou em laboratórios credenciados pelo MAPA?......

14 Como era a relação contratual entre a empresa e o fornecedor de grãos antes de 1996 (mal da vaca louca) e como é atualmente?

15 Quais as medidas adotadas pela empresa quando o governo decretou a liberalização da safra de grãos transgênicos 2002/03 no Brasil (porque a UE proíbe seu uso na ração)?

16 Como era a relação contratual entre a empresa e o fornecedor de premix antes de 1996 (mal da vaca louca) e como é atualmente?

17 Detalhe as mudanças contratuais que ocorreram entre a empresa com o seu cliente europeu, com o seu fornecedor de grãos e de premix 


\section{LISTA DE TABELAS}

Página

1 Exportações brasileiras para União Européia, quantidade total de carne de frango em pedaços e de carne de frango inteiro, 1999-2002.

!2 Exportações brasileiras de frango inteiro e em cortes, por destino, 1998-2002 em toneladas. 13

3 Tipos de clientes e o seu nível de preocupação com a segurança do alimento....... 63

4 Países europeus. 64

5 Alemanha e seus clientes 65

6 Holanda e seus clientes. 66

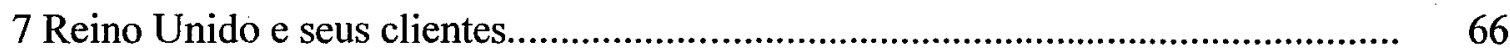

8 Programas de qualidade exigidos pelos clientes..................................................... 67

9 Programas de qualidade distribuídos por cada tipo de cliente em porcentagens..... 69

10 Exigências dos clientes europeus em relação à matéria-prima................................ 70

11 Exigências de cada cliente com relação a matéria-prima utilizada na produção de carne de frango............................................................................................. 71

12 Opiniões das empresas em relação às exigências dos clientes europeus................ 72

13 Medidas adotadas pelas empresas........................................................................ 73

14 Medidas adotadas por tipo de cliente................................................................... 74

15 Opinião das empresas em relação à atuação do setor público................................ 75

16 Matéria-prima frango ............................................................................................ 76

17 Relacionamento entre as empresas e seus fornecedores de grãos........................... 77

18 Relacionamento das empresas com os seus fornecedores de premix...................... 78 


\title{
O POSICIONAMENTO DA INDÚSTRIA AVÍCOLA FRENTE ÀS RESTRIÇÕES DO MERCADO CONSUMIDOR EUROPEU
}

\author{
Autor: ANDRÉA CRISTINA DÖRR \\ Orientador: Prof. PEDRO VALENTIM MARQUES
}

\section{RESUMO}

Visando estudar o posicionamento da indústria avícola frente às restrições do mercado consumidor europeu, foi conduzida uma pesquisa empírica que consistiu em se verificar as mudanças contratuais ocorridas entre as indústrias avícola e de premix e o produtor de grãos, levando-se em consideração as exigências do consumidor europeu quanto à qualidade do alimento. Utilizou-se como referencial teórico a Nova Economia Institucional (NEI) e a Teoria da Economia dos Custos de Transação (ECT). A pressuposição central desse trabalho baseou-se nas exigências do consumidor europeu, e a indústria avícola brasileira procura se adequar e garantir a qualidade dos alimentos que produz utilizando formas contratuais mais restritivas com seus fornecedores. Como conseqüência, contratos cada vez mais específicos estão sendo feitos entre a indústria avícola, as empresas de premix e os fornecedores de grãos. Como método de pesquisa, foi empregado um questionário, enviado para as 17 empresas avícolas habilitadas a exportar para a União Européia, contemplando questões sobre produção, sobre a relação das empresas com seus clientes europeus e com seus fornecedores de matéria-prima 
prima (frango, grãos e premix). Pelo fato de as variáveis terem sido do tipo qualitativas, o instrumental analítico adotado foi a análise univariada, sendo os dados codificados e tabulados posteriormente. A pesquisa foi complementada com três estudos de caso. Com taxa de retorno de $47,05 \%$ dos questionários, detectou-se que o nível de preocupação dos clientes em relação à segurança do alimento mostra-se altíssimo (média 4 numa escala de 0-4), em 4 tipos de clientes: indústria, supermercado, restaurante, traders. Verificou-se que os programas de qualidade exigidos pelos clientes são: Análise de Riscos e Pontos Críticos de Controle (HACCP), Procedimento Padrão de Sanitização e Higiene Operacional (SSOP) e Boas Práticas de Fabricação (BPF), com $90,24 \%, 87,80 \%$ e $82,92 \%$, respectivamente. A exigência da implantação do sistema de rastreabilidade foi de $60,97 \%$ para 41 clientes. As exigências dos clientes europeus em relação à matéria-prima mostraram que, com os dados agrupados dos 41 clientes, os itens: "não usar ingredientes de origem animal" e "não usar promotores de crescimento", tiveram freqüência de 24 e 22 , representando $58,53 \%$ e $53,65 \%$ respectivamente. Observou-se que as outras exigências listadas: "não usar aditivos", "não usar grãos geneticamente modificados" e "não usar antibióticos" também se aproximam das citadas anteriormente, com $48,78 \%, 43,90 \%$ e $39,02 \%$, respectivamente. Em relação aos fornecedores de matéria-prima, $100 \%$ das empresas adquiriam a matéria-prima frango, antes de 1996, via contrato integrado, e atualmente, continuam comprando da mesma forma. Verificou-se que 37,5\% das empresas compravam grãos via mercado e que, após a intensificação da legislação européia com relação à proibição do uso de grãos geneticamente modificados, as mesmas empresas afirmaram que nada mudou. Constatou-se, dentre as empresas que responderam ao questionário, que nenhuma delas produz o seu próprio premix. O premix é comprado de uma empresa que o prepara conforme as exigências de cada cliente. Os resultados permitem concluir que houve mudanças nas relações contratuais entre as empresas com seus fornecedores de matériaprima. 


\title{
POULTRY INDUSTRY POSITIONING AGAINST THE RESTRICTIONS OF THE EUROPEAN CONSUMER MARKET
}

\author{
Author: ANDRÉA CRISTINA DÖRR \\ Adviser: Prof. PEDRO VALENTIM MARQUES
}

\section{SUMMARY}

With the objective of studying the positioning of the poultry industry against the restrictions of the European consumer market an empiric survey was conducted, which consisted in verifying the contractual changes occurred between the poultry industry and premix, and between poultry industry and grain producers taking into account the needs of the European consumer in relation to food quality. As a theoretical approach the New Institutional Economics (NEI) and the Transaction Cost Economy Theory (ECT) were used. The main presupposition of this work was based on the needs of the European consumer, taking into account that the Brazilian poultry industry looks for adequating and guaranteeing its food quality using more restrictive contractual forms with their suppliers. Consequently, contracts are made each time more specific among the poultry industry, premix suppliers and grain producers. The used survey method was that of a questionnaire, sent to the 17 poultry companies authorized to export to the European Union, attending production questions, relationships between companies and their European clients and their raw material suppliers (poultry, beans and premix). Since all variables are of qualitative type, the used analytical tool was the 
univariate statistical analysis, data being coded and tabulated. After this, the survey was complemented with three case studies. With a $47.05 \%$ return of questionnaires, it was detected that the client preoccupation levels in relation to food safety was very high (mean value $=4$ in a $0-4$ scale) for 4 client types: industry, supermarket, restaurant, and traders. It was verified that the quality program required by the clients are Hazard Analysis and Critical Control Points (HACCP), Standard Sanitization Operation Procedure (SSOP) and Good Manufacturing Practices (BPF) with 90.24\%, 87.80\% e $82.92 \%$, respectively. The need of the introduction of the rastreability system represented $60.97 \%$ for 41 clients. The needs of the European clients in relation to raw material showed that, with the gathered data of the 41 clients, the items of not using products from animal sources and growth promoters, had frequencies of 24 and 22 which represents $58.53 \%$ and $53.65 \%$, respectively. It was also observed that the other listed needs: of not using additives, genetically modified grains and antibiotics were similar to the above cited needs with $48.78 \%, 43.90 \%$ and $39.02 \%$, respectively. Regarding the raw material suppliers, $100 \%$ of all companies purchased before 1996 poultry raw material via integrated contracts and nowadays continue to buy in the same way. It was verified that $37.5 \%$ of all companies bought grains via market and after the intensification of the European legislation in relation to the prohibition of the use of genetically modified grains, and they concluded that nothing had changed. It was observed that between the companies that answered the questions none produces its own premix, purchasing it from companies which attend the needs of each client. Results show that there were changes in the contractual relations between companies and their raw material suppliers. 


\section{INTRODUÇÃO}

A avicultura industrial brasileira defronta-se atualmente com a preocupação do atendimento das exigências de consumidores europeus no que diz respeito à qualidade da carne de frango exportada. Cabe à própria indústria avícola estabelecer normas e parâmetros visando o cumprimento destes requisitos para continuar a atuar no mercado europeu.

Neste trabalho, a ênfase é dada às restrições formais européias (regulamentos, diretivas, documentos etc) subentendendo-se representarem as exigências dos consumidores, sabendo-se que esses regulamentos podem representar barreiras nãotarifárias para o Brasil. $O$ conceito de barreiras não-tarifárias utilizado neste trabalho considera que essas barreiras são as leis, regulamentos, políticas ou práticas de um país que visam restringir o acesso de produtos importados em seu mercado. Pretende-se verificar também como a indústria avícola está se posicionando em relação às mudanças de relacionamento com os fornecedores de matérias-primas.

A preocupação do consumidor europeu em relação à qualidade do alimento está associada a graves situações de contaminação por alimentos. A crise da 
doença da vaca louca teve seu inicio efetivo em 1996, quando constatou-se a possibilidade da ligação entre a encefalopatia espongiforme bovina (BSE) ${ }^{1}$ nos animais e uma variação da Creutzfelt-Jakob Disease (CJD) nos humanos. O aparecimento da BSE levou a Comissão Européia a impor um embargo a numerosos produtos no setor de carne bovina. A Comissão teve o apoio do Parlamento Europeu na reestruturação dos seus serviços e na intensificação das ações comunitárias em prol da saúde pública. Além disso, citam-se outros problemas ocorridos nas últimas décadas, como salmoneloses em ovos na Grã-Bretanha (anos 80), presença de dioxina em insumos para alimentação (1998) e presença de fungicidas em carne de frango na Alemanha (Avicultura Industrial, 04/09/2002).

Tendo em vista esses problemas de contaminação, a Comissão das Comunidades Européias (2000) enfatiza que a segurança dos produtos alimentares de origem animal começa com a segurança da alimentação animal. Tal afirmação gerou a necessidade de criação de uma Autoridade Alimentar Européia cujo objetivo é o de contribuir para um nível elevado de proteção à saúde dos consumidores no domínio da segurança dos alimentos, que permite estabelecer e manter a confiança dos consumidores.

O mercado europeu é um mercado importante para as exportações brasileiras de frangos (corte e inteiro). A produção interna brasileira de frangos de corte somou 5.917.000 toneladas, sendo exportados 1.267 .531 toneladas, ou seja, $21,42 \%$. $\mathrm{O}$ primeiro destino dessa exportação é o Oriente Médio com 38,5\%; em segundo lugar, a Ásia, com 28,45\% e finalmente, em terceiro lugar, a Europa, com 21,96\%, segundo dados da Associação Brasileira dos Produtores e Exportadores de Frango (ABEF), em 2002.

\footnotetext{
' A doença da vaca louca é uma doença transmitida aos rebanhos por meio de alimentos produzidos a partir de ingredientes de origem animal, como farinhas de carne e de ossos. Essa epidemia teve início no Reino Unido e uma característica distinta de outras doenças é o longo período de incubação, que varia de 4 a 5 ano, durante o qual o animal parece ser perfeitamente saudável. Por isso, a BSE não foi reconhecida antes de 1986, quando muitos casos passaram do período de incubação e a doença se transformou numa epidemia.
} 


\subsection{Objetivos e hipótese}

O objetivo geral deste trabalho consiste em se verificar as mudanças contratuais ocorridas entre as indústrias avícola e de premix e o produtor de grãos, levando-se em consideração as exigências do consumidor europeu quanto à qualidade do alimento. Os objetivos específicos são: (i) identificar as exigências do consumidor europeu; (ii) estudar o comportamento da indústria avícola frente às exigências identificadas anteriormente; (iii) verificar qual a forma de governança prevalecente na indústria avícola em função de novas exigências de mercado; (iv) estudar se a especificidade dos ativos está mudando as formas contratuais.

A hipótese deste trabalho é que devido às exigências do consumidor europeu, a indústria avícola brasileira procura se adequar e garantir a qualidade dos alimentos que produz utilizando formas contratuais com seus fornecedores mais restritivas. Como conseqüência, contratos cada vez mais específicos estão sendo feitos entre a indústria avícola, as empresas de premix e os fornecedores de grãos.

\subsection{Estrutura de apresentação}

O objetivo e a hipótese deste trabalho estão descritos no capítulo 1. Em seguida é apresentada a revisão de literatura. No capítulo 3 apresenta-se o referencial teórico que embasa o trabalho. A metodologia é discutida no capítulo 4; e os resultados e discussões dos questionários e os estudos de caso são apresentados no capítulo 5. As conclusões são apresentadas no capítulo 6 . 


\section{REVISÃO DE LITERATURA}

Este capítulo está sub-dividido em 9 tópicos a saber: estrutura organizacional na União Européia; panorama da avicultura no Brasil; estabelecimentos avícolas habilitados; principais problemas de contaminações; preocupações da União Européia com o consumidor; segurança do alimento e certificação; controles de qualidade e por fim as principais alterações institucionais européias e brasileiras.

\subsection{Estrutura organizacional da União Européia}

Buscou-se neste tópico, mostrar como é a estrutura hierárquica da União Européia e as decisões que foram tomadas atualmente.

Em 1998, a União Européia foi instituída conforme estabelecido pelo Tratado de Amsterdã de 7 de novembro de 1997. Foi resultado de um processo de cooperação e integração iniciados em 1951 pelo Tratado de Paris que instituiu a Comunidade Européia do Carvão e do Aço (CECA). Em 1957, o Tratado de Roma criou a Comunidade Econômica Européia (CEE) e a Comunidade Européia de Energia Atômica (EURATOM). Há ainda outros tratados importantes como o Ato Único Europeu criado em 1986 e o Tratado da União Européia criado em $1992^{2}$.

Atualmente, a União Européia é formada por 15 Estados-Membros: Alemanha, Áustria, Bélgica, Dinamarca, Espanha, Finlândia, França, Grécia, Irlanda, Itália, Luxemburgo, Países Baixos, Portugal, Reino Unido e Suécia. O Conselho

\footnotetext{
${ }^{2}$ Disponível em: http:// www.comdelbra.org.br (27 jun. 2003)
} 
Europeu, reunido em 13 de dezembro de 1997 decidiu iniciar as negociaç̃os a partir de 1998 para o alargamento da União Européia aos dez países da Europa Central e Oriental e Chipre. Com isso, a partir de 2004 os novos Estados-Membros da União Européia serão: Chipre, Eslováquia, Eslovênia, Estônia, Hungria, Letônia, Lituânia, Malta, Polônia e República Checa. Outros países candidatos como a Bulgária, Romênia e Turquia ainda não tiveram seus assinados. Além desses países, existem outros países europeus que não fazem parte da União Européia e também não são candidatos: Albânia, Andorra, Antiga Republica Iugoslava da Macedônia, Bielorússia, Bósnia Herzegovina, Croácia, Islândia, Liechtenstein, Moldávia, Mônaco, Noruega, Rússia, São Marino, Sérvia e Montenegro, Suíça, Ucrânia e Vaticano ${ }^{3}$.

Segundo Quem é Quem na União Européia (2002) as instituições, órgãos e organismos da União Européia podem ser definidos da seguinte forma: i) instituições: Parlamento Europeu, Conselho da União Européia, Comissão Européia, Tribunal de Justiça das Comunidades Européias, Tribunal de Contas Europeu e Provedor de Justiça Europeu; ii) órgãos financeiros: Banco Central Europeu, Banco Europeu de Investimento, Fundo Europeu de Investimento; iii) órgãos financeiros: Comitê Econômico e Social Europeu e Comitê das Regiões; iv) órgãos interinstitucionais: Serviço de Publicações Oficiais das Comunidades Européias, Serviço de Seleção de Pessoas das Comunidades Européias e finalmente, v) organismos descentralizados da União Européia (agências): Agência da Comunidade Européia, Política Externa e de Segurança Comum e Cooperação Policial e Judiciária em Matéria Penal.

A seguir, estão delimitadas as estruturas hierárquicas de cada instituição e suas principais funções.

i)Parlamento Europeu: O Parlamento Europeu exerce três poderes fundamentais: legislativo, orçamental e de controle do executivo. Suas três funções essenciais são: partilha com o Conselho a função legislativa, ou seja, adota a legislação européia

\footnotetext{
${ }^{3}$ Disponível em: htpp://europa.eu.int/ (27 jun. 2003)
} 
(diretivas, regulamentos, decisões), divide com o Conselho a função orçamental, podendo alterar as despesas comunitárias e finalmente, adota o orçamento na sua integralidade. O poder de co-decisão constitui um dos poderes fundamentais do Parlamento, reforçando a sua capacidade de influenciar a legislação européia. $O$ Parlamento também exerce controle democrático sobre a Comissão, aprova a designação dos seus membros e dispõe do direito de votar uma moção de censura. Exerce igualmente um controlo político sobre o conjunto das instituições.

ii) Conselho da União Européia: O Conselho constitui-se na principal instância de decisão da União Européia e reúne-se em diferentes formações: política externa, finanças, educação, telecomunicações, etc. Assume várias funções: i) é o órgão legislativo da União em co-decisão com o Parlamento Europeu, ii) assegura a coordenação das políticas econômicas gerais dos Estados-Membros, iii) celebra, em nome da Comunidade, os acordos internacionais entre esta e um ou vários Estados ou organizações internacionais, iv) partilha a autoridade orçamental com o Parlamento, v) aprova as decisões necessárias à definição e à execução da política externa e de segurança comum, com base em orientações gerais definidas pelo Conselho Europeu e vi) assegura a coordenação da ação dos Estados-Membros e adota as medidas no domínio da cooperação policial e judiciária em matéria penal.

iii) Comissão Européia: A Comissão Européia materializa e defende o interesse geral da União. O presidente e os membros da Comissão são nomeados pelos EstadosMembros após aprovação pelo Parlamento Europeu. A Comissão é o motor do sistema institucional comunitário: i) graças ao direito de iniciativa legislativa, propõe os textos legislativos que são apresentados ao Parlamento e ao Conselho; ii) como instância executiva, assegura a execução da legislação européia (diretivas, regulamentos, decisões), do orçamento e dos programas adotados pelo Parlamento e pelo Conselho; iii) como guardiã dos Tratados, zela pelo respeito do direito comunitário, juntamente com o Tribunal de Justiça e iv) como representante da União em nível internacional, negocia acordos internacionais, de natureza essencialmente comercial e de cooperação. 
iv) Tribunal de Justiça das Comunidades Européias: Garante o respeito e a interpretação uniforme do direito comunitário. É competente para apreciar litígios em que podem ser partes os Estados-Membros, as instituições comunitárias, as empresas e os particulares.

v) Tribunal de Contas Europeu: Fiscaliza a legalidade e a regularidade das receitas e despesas da União e garante a correta gestão financeira do orçamento comunitário.

vi) Provedor de Justiça Europeu: Pode ser consultado por pessoas singulares (particulares) ou coletivas (instituições, empresas) que residam na União Européia.

\subsection{Panorama da avicultura no Brasil}

Canever et alli (1997) destacam que a avicultura comercial nacional se desenvolveu a partir do final da década de 50, no Estados do Sudeste, principalmente São Paulo. Posteriormente, na década de 70 , período em que houve profunda reorganização do complexo de carnes no Brasil, a atividade se desloca para a Região Sul, sendo o Estado de Santa Catarina o de maior destaque. Empresas que já possuíam negócios na produção de suínos e outras em cereais diversificaram-se para uma atividade nova, a produção e comercialização de carnes de frango, impulsionadas pela oferta de créditos para investimentos de longo prazo, associada à utilização de tecnologias importadas, no que se refere à genética e a técnicas ambientais, sanitárias, nutricionais, de abate e processamento. Os autores enfatizam ainda que o desenvolvimento da agroindústria de carnes de aves, entre outras causas, tem relação direta com a oferta local de grãos. É o caso do grande desenvolvimento da avicultura nos Estados do Sul do Brasil, na década de 70, quando as culturas de soja, milho e trigo consolidaram-se como as principais atividades agrícolas da região.

Por isso, conforme Coelho \& Borges (1999), o desenvolvimento da avicultura pode ser considerado como a síntese e o símbolo do crescimento e 
modernização do agronegócio no Brasil. Isso porque a atividade avícola reúne em sua estrutura funcional os três elementos mais importantes no cálculo econômico do capitalismo em sua configuração atual: tecnologia de ponta, eficiência na produção e diversificação no consumo. O livro "A história da avicultura no Brasil" (Arashiro, 1989) é uma importante fonte de referência sobre o desenvolvimento dessa atividade, podendose constatar que a avicultura industrial desenvolveu-se a partir dos anos 70. De início a indústria avícola visava prioritariamente o mercado interno, mas acabou alcançando posteriormente o mercado internacional.

Segundo a Empresa Brasileira de Pesquisa Agropecuária (EMBRAPA) (2002) o ambiente organizacional em que está inserida a cadeia de aves de corte envolve cooperativas, associações de classe, sindicatos e integrações de produtores e governo. Uma breve análise dessa cadeia mostra que o material genético tem origem no exterior e é repassado, mediante acordos com firmas estrangeiras, para as integradoras nacionais ou terceiros que produzem, localmente, os plantéis de avós e matrizes. As rações são principalmente distribuídas pelos integradores aos produtores de frangos, podendo existir firmas independentes para produção de rações. A produção de frangos faz parte do processo coordenado pelas indústrias frigoríficas. A indústria de insumos e equipamentos coloca-se como fornecedora de bens e serviços ao complexo agroindustrial. A industrialização de produtos e sua distribuição fazem parte da integração vertical, sendo que a venda a varejo no mercado interno se dá por terceiros. As exportações são comandadas pelas empresas integradoras. Esse trabalho objetiva estudar o relacionamento contratual entre a empresa avícola e as fábricas de premix e de grãos. 


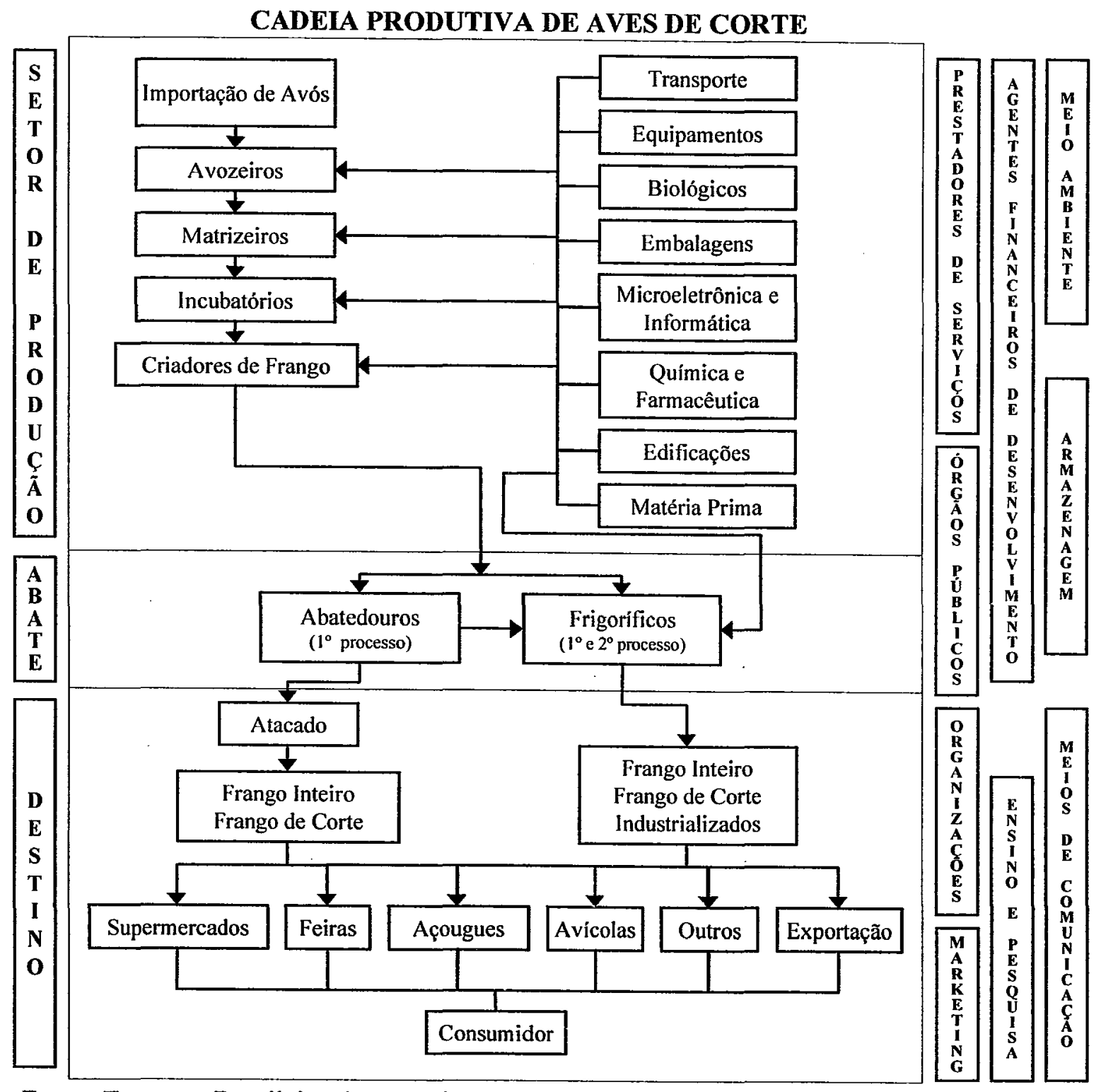

Fonte: Empresa Brasileira de Pesquisa Agropecuária (EMBRAPA) (2002)

Figura 1 - Cadeia produtiva do frango de corte.

Conforme a Tabela 1, observa-se que as exportações do Brasil somaram mais de 48 bilhões de dólares Free on Board (FOB), em 1999. O aumento das exportações pode ser analisado quando, em 2002, as divisas somaram mais de 60 bilhões de US\$ FOB. O Brasil destinou para a União Européia vários produtos representados 
por uma fatia de $28,61 \%$ do total de divisas. Entretanto, nos anos sucessivos houve uma pequena queda, somando $25,53 \%$, em 2002.

No Brasil as exportações de frango em pedaços e de frango inteiro representaram $0,94 \%$ e $0,88 \%$ respectivamente do total de divisas que entraram no país, em 1999. Observa-se que a participação das exportações de frango em pedaços aumentou significativamente, representando $1,46 \%$, em 2002, enquanto que as exportações de frango inteiro mantiveram-se estabilizadas com $0,75 \%$ do total de divisas, no mesmo ano. 
Tabela 1. Exportações brasileiras para a União Européia, quantidade total de carne de frango em pedaços e de carne de frango inteiro, 1999-2002.

\begin{tabular}{lrrrrrrrrr}
\hline & \multicolumn{1}{c}{1999} & & 2000 & & 2001 & & \\
& Descrição & US\$ F.O.B. & Part\% & US\$ F.O.B. & Part\% & US\$ F.O.B. & Part\% & US\$ F.O.B. & Part\% \\
\hline Total das exportações do Brasil & 48.011 .444 .034 & 100,00 & 55.085 .595 .326 & 100,00 & 58.222 .641 .895 & 100,00 & 60.361 .785 .544 \\
Total das exportações para UE & 13.736 .147 .001 & 28,61 & 14.784 .089 .380 & 26,84 & 15.113 .390 .695 & 25,04 & 14.865 .365 .206 \\
Exportações de frango em pedaços & 451.272 .948 & 0,94 & 445.006 .593 & 0,81 & 789.562 .877 & 1,36 & 881.282 .283 & 25,53 \\
Exportações de frango inteiro & 421.347 .015 & 0,88 & 359.439 .259 & 0,65 & 502.012 .643 & 0,86 & 453.708 .988 \\
\hline
\end{tabular}

Fonte: Brasil (2003) 
$\mathrm{Na}$ Tabela 2, as exportações brasileiras de frango inteiro tiveram um aumento significativo de $47,77 \%$ no período de 1998-2002. Esse aumento deveu-se principalmente, ao crescimento do volume exportado para o Oriente Médio, que em 1998 era de aproximadamente 227 mil toneladas, passando para mais de 451 mil toneladas em 2002. As exportações de frango inteiro para a União Européia também aumentaram, no período em análise, em 166,54\%. No entanto, as exportações de frango inteiro para o Mercosul reduziram-se de 55.782 toneladas em 1998, para 480 toneladas em 2002. Houve também redução das exportações de frango em cortes de 6.581 toneladas, em 1998, para 230 toneladas em 2002. As exportações de frango inteiro para outros mercados tiveram queda de $57,98 \%$. Dessa forma, observa-se que houve uma mudança de direcionamento do produto de outros mercados para a Ásia, África, União Européia e Oriente Médio.

Em relação às exportações de frango em pedaços, a União Européia liderou o aumento com 311,25\%, no ano de 1998. Pode-se atribuir esse aumento aos problemas sanitários do rebanho bovino como o mal da vaca louca e a febre aftosa. Observa-se também, que o aumento ocorreu nas exportações para a África, Ásia e Oriente Médio. Do total de frango em pedaços exportados, verifica-se que o aumento de $194,32 \%$ foi mais expressivo que o aumento das exportações de frango inteiro, que foram de $47,77 \%$.

Em 2002, foram exportadas aproximadamente 1.267.531 toneladas de frango inteiro e em cortes, classificando o Brasil como o segundo maior exportador mundial desse tipo de carne, perdendo apenas para os EUA. As exportações brasileiras, no mesmo ano, somando-se o volume de frango inteiro e em pedaços, tiveram como destino em primeiro lugar, o Oriente Médio, com 38,50\%; em segundo a Ásia com $28,45 \%$ e em terceiro a União Européia com $21,96 \%$. Segundo a FNP Consultoria \& Agroinformativos (2002) os países da União Européia para os quais o Brasil exportou frango em pedaços, em 2001, foram principalmente, Alemanha, Países Baixos, Reino Unido, Espanha e Itália. 
Tabela 2. Exportações brasileiras de frango inteiro e em cortes, por destino, de 1998 a 2002, em toneladas.

\begin{tabular}{|c|c|c|c|c|c|c|c|c|c|c|}
\hline Destino & \multicolumn{5}{|c|}{ frango inteiro } & \multicolumn{5}{|c|}{ frango em cortes } \\
\hline & 1998 & 1999 & 2000 & 2001 & 2002 & 1998 & 1999 & 2000 & 2001 & 2002 \\
\hline Mercosul & 55782 & 45474 & 35815 & 18253 & 480 & 6581 & 6516 & 5769 & 4567 & 230 \\
\hline $\begin{array}{l}\text { União } \\
\text { Européia }\end{array}$ & 6361 & 6980 & 9587 & 13979 & 16955 & 63561 & 81475 & 122696 & 223613 & 261400 \\
\hline África & 12176 & 12614 & 23100 & 18741 & 31947 & 4753 & 9463 & 11979 & 32162 & 44716 \\
\hline Ásia & 15771 & 19232 & 17293 & 20126 & 18449 & 151786 & 217974 & 252204 & 276508 & 342193 \\
\hline $\begin{array}{l}\text { Oriente } \\
\text { Médio }\end{array}$ & 227019 & 315390 & 349127 & 442866 & 451531 & 16401 & 20386 & 20664 & 29872 & 36560 \\
\hline Outros & 48022 & 22648 & 35554 & 19051 & 20178 & 4259 & 12394 & 22953 & 102340 & 42892 \\
\hline Total & 365131 & 422338 & 470476 & 533016 & 539540 & 247341 & 348208 & 436265 & 669062 & 727991 \\
\hline
\end{tabular}

Fonte: ABEF (2003) 
Para exportar frango para a União Européia, as empresas avícolas precisam estar habilitadas. O tópico seguinte, trata dessa questão.

\subsection{Estabelecimentos europeus}

$50 \%$ das importações da União Européia são em gêneros alimentícios. Mas para importar, os estabelecimentos devem seguir regulamentos ${ }^{4}$ e diretivas ${ }^{5}$ específicas. As Diretivas 71/118/CEE e 91/494/CEE, de 15 de fevereiro de 1971 e de 26 de junho de 1991, respectivamente, são as mais importantes no que se refere às condições sanitárias que regem o comércio intracomunitário e às importações de carnes frescas $^{6}$ de frango de corte, provenientes de outros países.

Brasil (2001) mostra que, a Diretiva Comunitária ${ }^{\circ}$ 92/46 exige que os produtos de origem animal importados de terceiros pela União Européia sejam provenientes de estabelecimentos habilitados pela Comissão Européia e que possuam um certificado sanitário e de saúde pública emitido pela União Européia. O processo de aprovação requer que as autoridades competentes dos países exportadores relacionem, para cada categoria de produto, os estabelecimentos responsáveis pela produção, garantindo que esses estabelecimentos atenda aos requerimentos de saúde pública e animal da União Européia.

Devido aos limites impostos pelos seus recursos, a Comissão Européia não pode cumprir todas as suas obrigações atuais em relação à avaliação das autoridades competentes e à verificação de estabelecimentos nos outros países. Dessa forma, a Comissão Européia organizaria auditorias nesses países com base em planos de controle

\footnotetext{
${ }^{4} \mathrm{O}$ Regulamento na legislação européia designa um ato de alcance geral, obrigatório para todos os seus elementos e diretamente aplicável aos Estados-Membros.

${ }^{5}$ A Diretiva na legislação européia obriga o seu cumprimento dos Estados-Membros, no que se refere ao resultado a ser atingido, deixando-lhes a escolha dos meios para alcançá-lo.

"A Diretiva define "carnes frescas"como todas as carnes, incluindo as carnes acondicionadas sob vácuo ou em atmosfera controlada, que não tenham sofrido qualquer tratamento destinado para assegurar a sua conservação, com exceção do tratamento a frio.
} 
semelhantes aos previstos para os Estados-Membros. Ao abrigo do novo acordo, os outros países exportadores deverão manter um plano de controle que forneça informação exata e atualizada sobre a organização geral e sobre a gestão dos sistemas de controle relevantes e manter registros atualizados sobre a aplicação desses sistemas, que deverão ser enviados à Comissão a seu pedido.

No Brasil, pela Resolução $n^{\circ} 7$ de 10 de abril de 2003, o Ministério da Agricultura, Pecuária e do Abastecimento (MAPA) estabeleceu novos procedimentos operacionais relativos à habilitação, auditoria e supervisão de estabelecimentos habilitados ao comércio internacional de carnes, ovos e seus derivados. A resolução prevê auditorias semestrais do Departamento de Inspeção dos Produtos de Origem Animal (DIPOA) nos estabelecimentos habilitados a exportar carne de frango (e seus derivados) para a União Européia e para os Estados Unidos. Nessas auditorias, serão verificados não só a adequação dos estabelecimentos à legislação específica brasileira, como também o atendimento de exigências específicas do país importador. Os auditores ganham condições de propor, quando for o caso, a exclusão do estabelecimento das listas de empresas habilitadas a realizar exportações./Atualmente, estão habilitadas para exportar para a União Européia 60 empresas avícolas.

A preocupação das autoridades européias em habilitar estabelecimentos dos quais importa alimentos, intensificou-se após a ocorrência de vários problemas de contaminação que ocorreram no mundo e na própria União Européia.

\subsection{Principais problemas de contaminação}

Episódios mundiais marcados por doenças animais amedrontaram e intimidaram o consumo de produtos alimentícios de origem animal e vegetal e definitivamente marcaram a necessidade de se implantar um programa de rastreabilidade na indústria avícola mundial: i) houve mudança nos hábitos e na cultura dos consumidores, com participação do Greenpeace do Partido Verde, de entidades de 
pesquisa e organismos governamentais; ii) Inglaterra, 1995 - Rainha declara intoxicação humana por Salmonella em ovos; iii) Inglaterra, 1996 - doença da vaca louca; iv) Bélgica, 1999 - crise da dioxina - fornecedor de óleo para ração utilizava óleo industrial; v) Alemanha, 2000 - Crise da dioxina 2001 - Resíduos de antibióticos em salsichas; vi) Itália, Portugal, Grécia, Dinamarca, Espanha e Ilhas Canárias - Casos da doença da vaca louca (Cerutti, 2002).

Discussões sobre a identificação da origem e do processo de produção de aves na Europa tiveram início depois da ocorrência dos problemas provocados pela doença da vaca louca, que tiveram início em 1996. Empresas avícolas brasileiras têm encontrado resíduos de nitrofurano ${ }^{7}$ em carcaças dos frangos exportados para a UE; a substância tem o seu uso proibido desde 1998 no Brasil, e desde 1996 na UE. Esta, por sua vez, está inspecionando $100 \%$ da carne oriunda do Brasil, para garantir que não conste nenhum resíduo (Avicultura Industrial, 27/03/2003). Mesmo com proibição pelo $\mathrm{MAPA}^{8}$, lotes de frangos vendidos aos países da Comunidade Européia continuaram sendo condenados por apresentarem vestígios de nitrofurano. Como as agroindústrias garantem que não utilizam mais tal substância, a suspeita recai sobre os fabricantes de rações, que são produzidas fora dos sistemas de integração (Avicultura Industrial, $31 / 03 / 2003)$.

"Na seqüência do acidente provocado pela contaminação de produtos alimentares pela dioxina, em 1999, que foi atribuída a alimentos adulterados para animais, a UE prevê igualmente reforçar os controles sobre e as rações animais" (Comunidades Européias, 2000, p. 6). A partir de 1 de julho de 2002, as novas regras européias que fixam os níveis máximos autorizados para a presença de dioxinas na

\footnotetext{
${ }^{7}$ Os nitrofuranos são antibióticos que servem para garantir o crescimento das aves. As substâncias deixam resíduos na carne e podem ser prejudiciais à saúde humana.

${ }^{8}$ A Portaria $n^{\circ} 89$, de 24 de março de 1998, proibiu a fabricação, importação, comercialização de rações e de aditivos alimentares contendo cloranfenicol, furazolidona e nitrofurazona em produtos destinados a alimentação humana. Essa medida foi tomada pelo MAPA considerando-se que a presença desses resíduos na carne, no leite e nos ovos pode constituir risco à saúde pública. Posteriormente, pela Instrução Normativa $n^{\circ} 38$ de 08 de maio de 2002, o MAPA proibe a utilização do grupo de nitrofuranos para preparação de insumos utilizados na pecuária nacional.
} 
alimentação humana e animal entraram em vigor. Dessa forma, todos os gêneros alimentícios e rações para animais que ultrapassarem os limites fixados pela Comissão Européia deverão ser excluídos da cadeia alimentar humana e animal.

\subsection{Preocupações da União Européia com o consumidor}

A Comissão Européia tem como um de seus objetivos a melhoria da qualidade de vida de seus cidadãos, o que implica em se criar medidas legislativas e outras ações para promover os interesses, a saúde e a segurança dos consumidores no mercado interno. Em nível internacional, ela procura garantir que os países candidatos apliquem os mesmos níveis elevados de proteção e segurança dos alimentos que foram comercializados.

A Comissão das Comunidades Européias (1997) tem por objetivos: verificar a adequação da legislação às expectativas dos consumidores, produtores, fabricantes e comerciantes; verificar em que medida as disposições relativas aos sistemas oficiais de controlo e inspeção permitem garantir uma alimentação sadia e segura, bem como a proteção do conjunto dos interesses dos consumidores; lançar um debate público sobre a legislação alimentar; permitir à Comissão propor medidas adequadas para desenvolver, se necessário, a legislação alimentar comunitária.

Outra obras da Comissão das Comunidades Européias (2001, p. 4) tem por objetivo assegurar um sistema de regulação que: i) "assegure um nivel de custo possível de ser atingido pelas empresas; ii) seja tão simples quanto possível e suficientemente flexível para reagir rapidamente ao mercado, associando-se aos interessados; e iii) forneça segurança jurídica e garanta a sua aplicação eficaz e efetiva, nomeadamente nos litígios transfronteiriços". As disposições da Diretiva 92/59/CEE, de 29 de junho de 1992, destinam-se a garantir a segurança dos produtos colocados no mercado, devendo fornecer aos consumidores informações relevantes que lhes permitam avaliar os riscos inerentes ao produto durante a sua vida útil normal. 
É importante que o setor avícola brasileiro tenha discernimento para entender as transformações que se anunciam nos sistemas de produção animal, haja vista o grau de exigência do consumidor europeu. Nesse sentido, o consumidor tem exigido qualidade dos produtos que consome, reforçando-se constantemente a questão da segurança dos alimentos, o que reforça a incorporação de valores até então não considerados devidamente pelo setor produtivo (Avicultura Industrial, 2003).

Segundo as Comunidades Européias ( p. 14-5, 2000), "nos últimos anos, a segurança do alimento tem suscitado um certo número de receios no tocante à saúde pública e a qualidade dos produtos alimentares tem sido objeto de uma atenção crescente. Uma pesquisa de opinião realizada pela Comissão Européia em 1997 revelou que a segurança do alimento era a principal preocupação dos consumidores. Esta constatação levou a Comissão a lançar uma campanha sobre a saúde dos consumidores e a segurança do alimento. Ao longo da campanha, a UE pretendeu explicar aos consumidores que existem autoridades européias e nacionais encarregadas de garantir a segurança dos alimentos, destacando, ao mesmo tempo, que o consumidor deve desempenhar um papel essencial para garanti-la".

Segue ainda que a qualidade dos alimentos que os europeus consomem tornou-se uma de suas principais preocupações. Também mostram maior interesse pelos modos e locais de produção dos alimentos, aumentando a procura por produtos provenientes de agricultura biológica ou de carne proveniente de animais criados em condições de bem-estar. 
Conforme a Comissão das Comunidades Européias (2000, p. 26) "a segurança dos produtos alimentares de origem animal começa com a segurança da alimentação animal". Para garantir esse processo, criou-se a Autoridade Européia para a Segurança dos Alimentos, pelo Regulamento (CE) 178/2002, de 28 de janeiro de 2002, o qual estabelece procedimentos de segurança que devem aplicado aos gêneros alimentícios, prevendo-se os fundamentos para garantir um elevado nível de proteção da saúde humana e dos interesses dos consumidores. Conforme seu $11^{\circ}$ artigo, a manipulação dos gêneros alimentícios e dos alimentos para animais, importados pela Comunidade, devem seguir os requisitos relevantes impostos pela legislação alimentar ou as condições reconhecidas pela Comunidade que entrarão em vigor a partir de 01 de janeiro de 2005.

Dessa forma, verifica-se a importância que a União Européia tem dado à questão da segurança do alimento e à preocupação com o bem-estar dos seus consumidores. No próximo tópico, serão abortados os temas Segurança do Alimento e Certificação.

\subsection{Segurança do alimento e certificação}

O conceito de segurança alimentar tem, na língua inglesa, dois significados: food security e food safety, sob o ponto de vista quantitativo e qualitativo, respectivamente. Na língua portuguesa não existe essa distinção e dessa forma, o enfoque quantitativo (segurança alimentar), refere-se ao abastecimento adequado de uma determinada população, enquanto que o qualitativo (segurança do alimento), garante ao consumidor um alimento com atributos de qualidade que seja do seu interesse (Spers, 1999). No presente trabalho, o enfoque está no conceito de food safety, ou seja, a preocupação crescente do consumidor europeu com a qualidade dos alimentos consumidos. 
Para Pessanha (2003, p.1) "segurança alimentar significa garantir alimentos com os atributos adequados à saúde dos consumidores, implicando em alimentos de boa qualidade, livre de contaminações de natureza química, biológica ou física, ou de qualquer outra substância que possa acarretar problemas à saúde das populações. Sua importância cresce com o desenvolvimento de novos processos de industrialização de alimentos e das novas tendências de comportamento do consumidor". No entanto, apesar de o autor usar o termo segurança alimentar para referir-se à segurança do alimento, sabe-se que há distinção entre os mesmos.

$\mathrm{O}$ autor distingue quatro campos de políticas envolvidos no conceito de segurança do alimento: a) a garantia da produção e da oferta agrícola; b) a garantia do direito de acesso aos alimentos; c) a garantia de qualidade sanitária e nutricional dos alimentos; e d) a garantia de conservação e controle da base genética do sistema agroalimentar.

Spers (1993, p.22-3) afirma que "perguntas relativas às etapas a serem percorridas por este alimento, sua procedência, seus riscos e embalagem mais adequada podem ser respondidas conhecendo-se seu comportamento ao longo da cadeia. Portanto, será a somatória das ações ao longo da cadeia alimentar que irá determinar a segurança de um produto. Pela sua própria característica, a indústria alimentícia é a que mais rapidamente pode reagir às mudanças e exigências quanto à segurança do alimento".

Atualmente, duas tendências mundiais complementares são discutidas, a introdução do conceito de rastreabilidade do alimento e uma maior exigência por parte dos consumidores com relação à rotulagem alimentar. A primeira envolve a recomposição da história do produto alimentício, com identificação e registro de cada etapa do processo de fabricação e o segundo, constitui-se na tendência que evidencia um consumidor mais exigente, que valoriza as diversas opções de certificação dos alimentos. 
A certificação de alimentos surge num mercado onde há assimetria informacional, com a desconfiança dos consumidores em relação à qualidade dos produtos que compram, como, por exemplo, a desconfiança dos consumidores europeus, que aumentou com o aparecimento da doença da vaca louca e dos alimentos transgênicos. Assim, a certificação tem alguns prós e contras como a geração de custos associados ao processo. Nesse contexto, surgem mecanismos organizacionais de garantia de qualidade, como a padronização, a certificação e a rastreabilidade para suprir essa informação (Lazzarotto, 2001).

/ "Certificação é a definição de atributos de um produto, processo ou serviço e a garantia de que eles se enquadram em normas pré-definidas. Assim, a certificação envolve normas, seja na esfera privada, pública, nacional ou internacional (ambiente institucional) e um órgão certificador com poder de monitoramento e exclusão (ambiente organizacional)" (Nassar, 1999, p.16). A certificação possui dois objetivos, do lado da oferta é um instrumento que oferece procedimentos e padrões básicos permitindo às empresas participantes gerenciar o nível de qualidade dos seus produtos e garantir um conjunto de atributos. Do lado da demanda, a certificação espera informar ao consumidor que aquele determinado produto tem certos atributos por ele procurados (Nassar, 1999)./

É importante ressaltar que "essa demanda por certificação em alimentos não só advém dos consumidores, mas indiretamente dos supermercados e importadores. O varejo de alimentos, com um expressivo poder de barganha, e o mercado internacional, globalizado e com grandes barreiras não-tarifárias, repassam essas exigências aos agentes à montante do sistema agroindustrial, chegando até ao produtor rural" (Spers 2000, p.303)./

A segurança do alimento pode ser garantida com a implantação de programas de qualidade ao longo da cadeia produtiva avícola. No próximo tópico, estão apresentados os principais programas de qualidade implantados por empresas avícolas. 


\subsection{Controles da qualidade}

Dentre os programas de qualidade mais importantes, pretende-se fazer uma breve explicação sobre rastreabilidade; Boas Práticas de Fabricação (BPF); Análise de Riscos e Pontos de Controle (HACCP) e Serviço Europeu de Inspeção e Segurança do Alimento (EFSIS) e Internacional Standartization Organization (ISO).

\subsubsection{Rastreabilidade}

O conceito de rastreabilidade, conforme Sans e Fontguyon (1998), citados por Jank (1999), consiste "na capacidade de reencontrar o histórico ou a localização de um produto qualquer através de meios de identificação registrados". A definição adotada pelo Regulamento (CE) $n^{\circ}$ 178/2002, de 28 de janeiro de 2002, referese à "capacidade de detectar a origem e de seguir o rasto de um gênero alimentício, de um alimento para animais, de um animal produtor de gêneros alimentícios ou de uma substância, destinados a serem incorporados em gêneros alimentícios ou em alimentos para animais, ou com probabilidades de o ser, ao longo de todas as fases da produção, transformação e distribuição" (artigo $3^{\circ}, \mathrm{n}^{\circ} 15$ ).

Vinholis e Azevedo (2000, p.12) afirmam que "um sistema de rastreabilidade, seja ele informatizado ou não, permite seguir/ rastrear informaçṍes de diferentes tipos (referente ao processo, produto, pessoal e/ou serviço) a jusante e/ou a montante de um elo da cadeia ou de um departamento interno de uma empresa. A rastreabilidade possibilita a obtenção de um histórico do produto, sendo que a complexidade do conteúdo deste histórico dependerá do objetivo que se pretende alcançar. Este objetivo pode ser influenciado pelas estratégias adotadas e pelo ambiente em que a empresa está inserida".

${ }^{9}$ SANS, P.; FONTGUYON, G. Formes de coordination et qaulité des produits: les effects de la crise . dite de la vaca folle sur la fillière viande bovine, 1998. 
Portanto, o conceito está associado à idéia de se identificar um produto, em diferentes etapas do seu processo de produção, seja em termos locacionais, seja em termos dos seus atributos ou de suas características intrínsecas, por meio de um sistema de codificação impresso no mesmo. Haveria um conjunto de informações comprovadamente documentadas para respaldar o sistema de codificação.'

O objetivo da rastreabilidade é, segundo Lombardi (1998), garantir ao consumidor um produto seguro e saudável, por meio do controle de todas as fases de produção, industrialização, transporte/distribuição e comercialização, possibilitando uma perfeita correlação entre o produto final e a matéria-prima que lhe deu origem. $/$

Para Moe (1998), num sistema de rastreabilidade é importante a amplitude de sua aplicação: rastreabilidade de uma cadeia produtiva e rastreabilidade interna a uma organização pertencente a um dos elos da cadeia. Quando se trata da rastreabilidade ao longo de uma cadeia produtiva, duas formas de se gerenciar as informações podem ser definidas: i) as informações são armazenadas em cada elo da cadeia, seguindo apenas a identificação do produto ao longo da cadeia; ii) as informações seguem com o produto ao longo da cadeia. Essa forma de rastreabilidade é realizada quando se necessita que o consumidor visualize a informação, para fins legais ou para a diferenciação do produto.

Segundo Cerutti (2002) a demanda da rastreabilidade ocorre em quatro importantes níveis: (i) demanda pela organização: rastreabilidade como fator de segurança do produtor; no gerenciamento de crises; como base para a implantação do Controle Estatístico de Processo (CEP); como uma ferramenta para a melhoria contínua; (ii) demanda pelo cliente: rastreabilidade como fator de segurança ao cliente; como garantia para identificação e controle das causas de reclamações; como garantia de responsabilidade das penalizações morais e econômicas de recall e gerenciamento de crises; (iii) demanda legal: rastreabilidade conforme o Regulamento (CE) 178/2002, 
artigo 18 e (iv) demanda social: a implantação de um sistema de rastreabilidade verticalizada entre os diferentes elos da cadeia produtiva minimizam o impacto e as perdas econômicas e impactos da organização, do cliente e da saúde pública.

Percebe-se que a rastreabilidade torna-se um instrumento cada vez mais importante, pois privilegia as preferências e a satisfação do consumidor, decorrentes da sua crescente preocupação com a qualidade e a segurança dos alimentos que consome. No entanto, os pontos de alerta na implantação do programa de rastreabilidade para a indústria avícola compreendem: tendência à burocratização em nível europeu e na empresa (definir por uma sistemática simples, objetiva e informatizada); zelo pela informação; aumento dos custos para as empresas; ética com o valor da informação do cliente e da empresa; distinguir as intenções de um cliente daquele oportunista; período de guarda dos registros superior ao de validade do produto (Cerutti, 2002).

Lombardi (1998) afirma que com respeito à segurança do alimento, a rastreabilidade é uma garantia dada ao consumidor por meio de legislação comunitária, que lhe dá certeza de estar consumindo um produto que está sendo controlado em todas as fases da produção: da fazenda ao prato final.

A avicultura ainda não dispõe de um programa de rastreabilidade para aves denominado por "SISAVE", como a pecuária de corte, que já tem o SISBOV $^{10}$, mas já opera com uma série de normas como a Análise de Risco e Controle de Pontos Críticos (HACCP); ou a Boas Práticas de Higiene (BPH). De toda forma, a própria comunidade internacional (especialmente os países integrantes da União Européia) ainda discute a normatização do processo de rastreabilidade. Apesar do sistema de rastreabilidade ainda não ser uma exigência legislativa pelo consumidor europeu, as empresas avícolas brasileiras estão se adiantando com a sua implantação.

\footnotetext{
${ }^{10}$ Sistema Brasileiro de Identificação e Certificação de Origem Bovina e Buvalina instituído pela Instrução Normativa $n^{\circ} 1$, publicada no Diário Oficial da União de 10 jan. 2002. Seção 1, p.6.
} 


\subsubsection{Boas Práticas de Fabricação (BPF)}

O programa de qualidade Boas Práticas de Fabricação entrou em vigor no ano de 2000, baseado na legislação dos EUA e da União Européia, permitindo um controle rigoroso do ambiente onde seria produzido o produto, por meio de procedimentos higiênico-sanitários. A efetiva implementação de Boas Práticas de Fabricação (BPF) em toda a cadeia alimentar - desde a produçã̀o de ração, alimentos balanceados e suplementos para animais, até o produto final na mesa do consumidor - é fundamental para colocar o Brasil em um patamar mais elevado quando se trata de segurança dos alimentos. O certificado do BPF é conferido às empresas que conseguem provar que estão cumprindo todos os itens da norma, divididos em várias categorias.

Os aspectos gerais sobre os quais o Manual de Boas Práticas de Fabricação deve atuar são: i) matérias-primas; ii) edificações e instalações; iii) higienização; iv)higiene pessoal; v)fabricação; vi) identificação, armazenamento e distribuição; vii) controle de pragas; viii) garantia e controle de qualidade e ix) garantia de rastreabilidade.

Pela Instrução Normativa $n^{\circ} 1$ de 13 de fevereiro de 2003, foi aprovado o Regulamento Técnico sobre as Condições Higiênico-Sanitárias e de Boas Práticas de Fabricação para estabelecimentos brasileiros fabricantes e industrializadores de alimentos para animais e também o Roteiro de Inspeção, estabelecendo um prazo de 180 dias para que o estabelecimento atenda às especificações.

\subsubsection{Análise de Riscos e Pontos Críticos de Controle (HACCP)}

No Brasil, o Hazard Analysis and Critical Control Points (HACCP) teve sua implantação na indústria do pescado a partir de 1991, sob a coordenação do MAPA. As medidas foram tomadas tendo em vista a exigência dos Estados Unidos e da União Européia, em seus conceitos de equivalência de sistemas de inspeção e de aplicação de 
programas, com base no sistema de HACCP. Esse sistema, adotado pelos principais mercados mundiais, basicamente assegura que os produtos industrializados, sejam elaborados sem riscos à saúde pública; apresentem padrões uniformes de identidade $\mathrm{e}$ qualidade e atendam às legislações nacionais e internacionais, no que tange aos aspectos sanitários de qualidade e de integridade econômica.

O sistema HACCP, segundo Gattegno (1994) ${ }^{11}$, citado por Spers (1999), está baseado no controle e no monitoramento dos pontos críticos de controle, em que possa haver a contaminação do alimento. Esse sistema é uma tentativa de se implementar, padronizar e avaliar programas de segurança do alimento; tem a finalidade de prevenir potenciais riscos relacionados à segurança do alimento, garantindo a segurança do processo.

Conforme a Suinocultura Industrial (1999), o HACCP busca garantir a segurança e a qualidade dos alimentos em todas as etapas de produção e distribuição, até atingir o consumidor final. É composto de sete etapas fundamentais: 1) identificar os perigos potenciais em todos os estágios de produção desde a matéria-prima (suíno, soja, etc.) até a manufatura e distribuição; 2) reconhecer os pontos críticos $d$ processo produtivo que podem ser controlados para eliminar os perigos ou minimizar a possibilidade de sua ocorrência; 3) a empresa/fiscalização deve estabelecer os limites críticos - de contaminação, por exemplo - aceitáveis para um determinado produto; 4) organizar um sistema para monitorar o controle dos pontos críticos por meio de testes ou de observações predeterminadas; 5) elaborar ações corretivas a serem tomadas pela área de produção sempre que o monitoramento indicar pontos críticos fora de controle; e 6) criar procedimentos de verificação que abranjam testes suplementares e procedimentos para confirmar se o sistema está funcionando de maneira adequada; e 7) elaborar um histórico de produção por meio de documentação descritiva dos procedimentos executados na elaboração do produto.

" GATTEGNO, I. HACCP: lê futur de la sécurité alimentaire. RIA, n.524, p.124-27,1994. 
O Regulamento (CE) 1774/2002, Capítulo VI, que trata sobre controles e inspeções, ressalta no artigo $25^{\circ}$, que os operadores e os proprietários de unidades intermediárias tomarão todas as medidas necessárias para dar cumprimento ao regulamento. Assim, deverão criar, implementar e manter um processo permanente, concebido de acordo com os princípios do sistema de análise de risco e dos pontos de controlo críticos (HACCP). Devem nomeadamente: a) detectar e controlar os pontos de controlo críticos nas unidades; b) fixar e aplicar métodos de monitorização e controle desses pontos de controlo críticos; c) no caso das unidades de transformação, colher amostras representativas a fim de verificarem o cumprimento: i) para cada lote transformado, das normas estabelecidas pelo presente regulamento, para os produtos em questão; e ii) dos níveis máximos permitidos de resíduos físico-químicos fixados na legislação comunitária; d) registrar e conservar, por um período mínimo de dois anos, os resultados dos diversos controles e testes referidos nas alíneas b) e c), para apresentação às autoridades competentes; e) criar um sistema que garanta a rastreabilidade de cada lote expedido. Destaca-se que as empresas avícolas exportadoras devem, obrigatoriamente, ter o Sistema APPCC implantado para poderem exportar seus produtos.

\subsubsection{Sistema Europeu de Inspeção e Segurança do Alimento (EFSIS) e Internacional Standartization Organization (ISO)}

A Internacional Standartization Organization é uma organização sediada em Genebra (Suíça), reconhecida e aceita internacionalmente no estabelecimento de normas técnicas desenvolvidas e avaliadas no âmbito de competência de suas delegações nacionais. No Brasil, o Instituto Brasileiro de Normas Técnicas (INMETRO) representa o Comitê Brasileiro de Certificação na ISO. A Associação Brasileira de Normas Técnicas (ABNT) é o organismo de certificação brasileiro, credenciado pelo INMETRO, para atuação em certificação de sistemas de garantia de qualidade no país. Em nível internacional, o INMETRO é reconhecido pelo International Accreditation Fórum (IAF) como organismo credenciador, inclusive para a certificação de Sistemas da Qualidade, 
sendo responsável pelo credenciamento dos próprios organismos de certificação no Brasil. Conforme os critérios oficializados pelo IAF, os atos de credenciamento e de certificação são voluntários. Portanto, são acordos de mercado entre certificador e cliente.

O Serviço Europeu de Inspeção e Segurança de Alimento, sediado no Reino Unido, é um serviço independente de inspeção de alimentos, que presta aos varejistas, fabricantes e fornecedores serviços de consultoria e certificação para as suas operações, baseado na ISO e no HACCP. Possuir a certificação emitida pelo EFSIS permite que a empresa venda seus produtos diretamente ao varejo da Europa.

Tendo-se em vista as preocupações com a garantia e segurança dos alimentos, várias medidas legislativas foram tomadas, tanto na União Européia como no Brasil.

\subsection{Principais alterações institucionais européias}

Dentre as principais alterações institucionais implementadas na União Européia em função do aumento das exigências dos consumidores europeus e do nível de preocupação com relação à origem e segurança dos alimentos, citam-se: ingredientes de origem animal, grãos geneticamente modificados, antibióticos e aditivos. Será feita em seguida uma breve apresentação sobre cada um destes tópicos baseando-se na literatura consultada.

\subsubsection{Ingredientes de origem animal}

Devidos aos problemas ocorridos pela doença da vaca louca, várias medidas de prevenção foram adotadas pelos governos do Reino Unido e pela União Européia. As autoridades européias estão preocupadas com os ingredientes de origem animal, como mostra a Diretiva 90/667/CEE, de 27 de novembro de 1990, que 
estabelece normas sanitárias para a eliminação e a transformação de resíduos animais antes de sua colocação no mercado e para prevenir a propagação de agentes patogênicos nos alimentos para animais.

O Regulamento $\mathrm{n}^{\circ}$ 999/2001, de 22 de maio de 2001, determina regras para a prevenção, o controle e a erradicação das encefalopatias espongiformes transmissíveis (EET) nos animais. O Regulamento prevê o controle da produção e da introdução no mercado tanto de animais vivos como de produtos de origem animal e, em certos casos específicos, da exportação. A Decisão da Comissão 2002/934/CE de 28 de novembro de 2002, aprova programas de vigilância das encefalopatias espongiformes transmissíveis em determinados Estados-Membros da UE para 2003.

Na União Européia, o Regulamento (CE) $n^{\circ}$ 1774/2002, de 03 de outubro de 2002 , entrou em vigor em $1^{\circ}$ de maio de 2003 e estabelece regras sanitárias relativas aos subprodutos animais não destinados ao consumo humano, regras de sanidade animal e de saúde pública relativas à recolha, ao transporte, à armazenagem, ao manuseamento, à transformação e à utilização ou eliminação de subprodutos animais, a fim de evitar que esses produtos apresentem riscos ao consumidor. $O$ novo regulamento europeu classifica os subprodutos animais em três categorias - baseadas no risco potencial para outros animais, para o homem e para o meio ambiente - estabelecendo também seu uso ou disposição final. A Categoria 1 engloba resíduos considerados de alto risco. Devem ser incinerados ou dispostos em aterros sanitários (nesse caso, passando por tratamento prévio, por calor). Na Categoria 2 estão inclusos subprodutos considerados de baixo risco (mesmo assim têm seu uso proibido em rações). Assim, somente matérias-primas incluídas na Categoria 3 terão seu uso autorizado em rações animais. Para ser classificada nessa categoria, a matéria-prima deve provir de animais saudáveis abatidos para o consumo. Além disso, os Estados-Membros proíbem a alimentação "de animais de criação mantidos, engordados ou criados para a produção de alimentos com proteínas 
animais transformadas ${ }^{12 \%}$ conforme o artigo $1^{\circ}$ da Decisão da Comissão 2002/248/CE, de 27 de março de 2002.

O Brasil não apresentou casos da doença da vaca louca. Com o objetivo de evitar doenças como essa se disseminassem no Brasil, foi criada a Portaria 365, de 03 de julho de 1996, estabelecendo a proibição, em todo o território nacional, do uso na alimentação de ruminantes (bovinos, ovinos e caprinos) de proteína in natura e de farinhas de carne e de ossos provenientes desses animais. Posteriormente, a Portaria $\mathrm{n}^{\circ}$ 290 de 16 de julho de 1997, mais rígida, proíbe o uso de qualquer fonte de proteína de ruminantes na alimentação de ruminantes. E por fim, a Instrução Normativa ${ }^{\circ} 15$ proíbe também a utilização de cama de aviário na alimentação dos mesmos, justificado pelo fato de a ração para aves ser composta de subprodutos de origem animal.

Por meio da Portaria Ministerial n 516 , de 09 de dezembro de 1997, o Brasil declarou-se livre da encefalopatia espongiforme bovina, pois a alimentação dos bovinos no país é essencialmente composta de pastagens naturais ou cultivadas; os suplementos alimentares, quando utilizados, são de natureza vegetal. Pelo fato de não ter sido constatado nenhum caso de vaca louca no Brasil, as empresas avícolas que destinam sua produção para o mercado interno utilizaram ingredientes de origem animal para compor a ração dos frangos de corte. Entretanto, constata-se que o consumidor brasileiro está menos preocupado com questões de segurança do alimento.

\footnotetext{
${ }^{12}$ Decisão do Conselho 2000/766/CE, artigo $1^{\circ}$, entende-se por "por "proteínas animais transformadas" a farinha de carne e ossos, a farinha de carne, a farinha de ossos, a farinha de sangue, o plasma seco e outros produtos do sangue, as proteinas hidrolisadas, a farinha de cascos, a farinha de chifres, os subprodutos do matadouro de aves, a farinha de penas, os torresmos secos, a farinha de peixe, o fosfato bicálcico, a gelatina e quaisquer outros produtos semelhantes, incluindo misturas, os alimentos para animais, os aditivos destinados à alimentação animal e as pré-misturas para alimentos para animais contendo estes produtos".
} 


\subsubsection{Grãos geneticamente modificados}

O organismo geneticamente modificado é definido como "qualquer organismo, com exceção do ser humano, cujo material genético tenha sido modificado de uma forma que não ocorre naturalmente, por meio de cruzamentos e/ou de recombinação natural", conforme estabelece a Diretiva 2001/18/CE de 12 de março de 2001.

O Regulamento (CE) $\mathrm{n}^{\circ} 49 / 2000$, de 10 de janeiro de 2000 , refere-se à menção obrigatória na rotulagem do produto de determinados gêneros alimentícios, produzidos a partir de organismos geneticamente modificados, que tiver uma proporção superior a $1 \%$ por produto. Dessa forma, todos os ingredientes de alimentos humanos e animais terão de ser rotulados, caso sejam produzidos com transgênicos na percentagem acima da permitida, com base no novo sistema de rastreabilidade.

Pretende-se com a rotulagem garantir o direito de o consumidor saber o que está comprando. A exigência da rastreabilidade no comércio internacional tem por objetivo evitar que a carga de grãos não seja acidentalmente contaminada ou sabotada. Por isso, exige-se a certificação, e empresas ou consultores independentes acompanham o produto desde o plantio de grãos até o desembarque e transporte ao destino final, incluindo avaliação na colheita, armazenagem e eventuais processamentos ( $O$ Estado de São Paulo, 01/11/2001).

O Regulamento (CE) $n^{\circ}$ 258/97, de 27 de janeiro de 1997, tem por objetivo a colocação no mercado de novos alimentos ou ingredientes alimentares, desde que atendam às exigências em termos de saúde pública, do ambiente e levem em conta a informação dos consumidores, integrando-se numa das seguintes categorias: a) Alimentos e ingredientes alimentares que contenham ou consistam em organismos geneticamente modificados, na acepção da Diretiva 90/220/CEE; b) Alimentos e 
ingredientes alimentares produzidos a partir de organismos geneticamente modificados, mas que não os contenham.

O Regulamento (CE) $\mathrm{n}^{\circ}$ 50/2000, de 10 de Janeiro de 2000, refere-se à rotulagem dos gêneros alimentícios e ingredientes alimentares que contenham aditivos $\mathrm{e}$ aromas geneticamente modificados ou produzidos a partir de organismos geneticamente modificados. O objetivo desse regulamento é harmonizar, em nível comunitário, as condições em que serão feitas as rotulagens garantindo que todos os consumidores sejam informados da mesma e evitando novos obstáculos ao comércio intra-comunitário impostos por legislações diferentes.

No Brasil, a Lei ${ }^{\circ} 8.974$, de 05 de janeiro de 1995, estabelece normas para o uso das técnicas de engenharia genética e para a liberação no meio ambiente de organismos geneticamente modificados. Proíbe atividades e projetos de pessoas físicas enquanto agentes autônomos independentes, ou seja, a produção propriamente dita. Embora o plantio, a comercialização e a importação de transgênicos estejam proibidos no Brasil, as indústrias de alimentos precisam adotar medidas de controle para garantir que não estão comprando insumos derivados de plantios ilegais de transgênicos.

Pela Medida Provisória 113, de 26 de março de 2003, o governo federal estabelece normas para a comercialização da soja transgênica da safra 2003, que está sendo colhida no estado do Rio Grande do Sul. Com base na Medida, está liberada a venda da produção no mercado externo e interno. Conforme Avicultura Industrial (05/05/2003), a Medida indica que a rotulagem dos alimentos destinados ao consumo animal que contenham organismos geneticamente modificados, acarretará num aumento de pelo menos $10 \%$ nos custos das indústrias de ração do país.

A Medida Provisória, entretanto, gerou críticas entre produtores, traders, cooperativas, ambientalistas e órgãos de defesa do consumidor. Há dúvidas sobre a regulamentação da medida e sobre a fiscalização da presença de organismos 
geneticamente modificados ao longo da cadeia produtiva. A principal consumidora de farelo do país, a indústria avícola, teme restrições da União Européia, que absorve $27 \%$ das exportações brasileiras e proíbe a importação de frango alimentado com ração transgênica (Avicultura Industrial, 31/03/2003).

O Decreto $\mathrm{n}^{\circ} 4.680$ de 24 de abril de 2003 regulamenta o direito à informação quanto aos alimentos e ingredientes alimentares destinados ao consumo humano ou animal que contenham ou sejam produzidos a partir de organismos geneticamente modificados. Posteriormente, a Lei ${ }^{\circ} 10.688$ de 13 de junho de 2003 estabelece os produtos destinados ao consumo humano ou animal, deverão apresentar rotulagem quando tiverem a presença de organismos geneticamente modificados superior ao limite de $1 \%$. No entanto, esse decreto de rotulagem dos transgênicos foi republicado dia 28 de abril no Diário Oficial da União. O texto ratifica a informação de que a exceção de exigência de rotulagem contendo a informação de transgenia excluirá os produtos que tenham sido produzidos em regiões classificadas pelo MAPA como livres de OGMs, ou cujo grão tenha sido certificado como não transgênico, conforme determina a Medida Provisória 113 (Avicultura Industrial, 29/04/2003).

A liberação da safra de soja transgênica pela Medida Provisória 131 de 25 de setembro de 2003, dividiu a opinião dos produtores orgânicos. Contrários por princípio ao uso de grãos geneticamente modificados, os agricultores orgânicos temem que o processo de certificação de suas culturas, pelos órgãos que estabelecem o padrão de qualidade orgânica, seja dificultado, diante da possibilidade de contaminação de suas lavouras por sementes transgênicas. Por outro lado, a rejeição a alimentos transgênicos por consumidores mais exigentes e preocupados com responsabilidade sócio-ambiental poderá levar, assim como ocorreu na Europa, a um aumento da procura por orgânicos produtos de maior valor agregado que costumam dar mais lucros para quem os produz e, sobretudo, os comercializa (Avicultura Industrial, 29/09/2003).

Segundo a Medida Provisória 131, o MAPA, mediante portaria, poderá excluir do regime dessa medida os grãos de soja produzidos em áreas ou regiões nas 
quais não se verificou a presença de organismo geneticamente modificado. Cita-se como exemplo o Estado do Paraná, onde está proibido o plantio, a manipulação, a importação e a industrialização de transgênicos.

\subsubsection{Antibióticos}

A União Européia tem sido o berço de grandes transformações que estão ocorrendo na alimentação humana e animal. Foi na Dinamarca, por exemplo, que em meados dos anos 90 começou a proibição do uso de antibióticos promotores de crescimento dos animais, estendida atualmente para todo o mundo, incluindo o Brasil (Avicultura Industrial 21/06/2002).

A Diretiva 96/22/CE, de 29 de abril de 1996, proíbe a administração aos animais de exploração ${ }^{13}$ de substâncias com efeitos hormonais. Os países terceiros cuja legislação autorize a colocação no mercado e a administração a animais desses hormônios não podem constar numa das listas de países previstos na legislação comunitária dos quais os Estados-membros estão autorizados a importar.

O Parlamento da União Européia pretende tomar mais uma medida voltada ao aumento da segurança do alimento no continente: a redução, em um ano, do prazo-limite para o banimento dos últimos quatro antibióticos promotores de crescimento usados na produção animal. Os antibióticos Avilamicina e Flavomicina estarão definitivamente proibidos na UE a partir de $1^{\circ}$ de janeiro de 2005 (e não mais de 2006, como definido anteriormente), a Monensina Sódica e Salinomicina sejam banidas a partir de 2008. O banimento destes antibióticos a partir de $1^{\circ}$ de janeiro de 2005 significa que, após essa data, nenhum alimento de origem animal que contenha esses

\footnotetext{
${ }^{13}$ Segundo o Artigo $1^{\circ}, \mathrm{n}^{\circ} 2$, animais de exploração são animais domésticos das espécies bovina, suina, ovina e caprina, os solípedes, as aves de capoeira e os coelhos domésticos, bem como os animais selvagens das espécies acima referidas e os ruminantes selvagens, desde que tenham sido criados numa exploração.
} 
antibióticos poderá ser produzido ou ingressar na União Européia (Avicultura Industrial, 29/11/2002).

\subsubsection{Aditivos}

Conforme a Diretiva 89/107/CEE, de 21 de dezembro de 1988 da União Européia, entende-se por aditivo alimentar qualquer substância não consumida habitualmente como alimento em si mesma e habitualmente não utilizada como ingrediente característico na alimentação.

Essa diretiva refere-se à aproximação das legislações dos Estadosmembros da União Européia no que diz respeito aos aditivos que podem ser utilizados nos produtos destinados à alimentação humana. A diretiva é aplicável aos aditivos alimentares destinados como ingredientes no fabrico ou preparação de um gênero.

Os deputados europeus pretendem proibir o uso de coccidiáticos e dos histomonostáticos, aditivos alimentares utilizados, respectivamente, no controle de doenças em frangos e perus, a partir de $1^{\circ}$ de janeiro de 2009. A Comissão Européia está propondo, também, o reforço e a simplificação da legislação sobre a avaliação da segurança e as autorizações de colocação no mercado, dos aditivos destinados à alimentação animal. De acordo com a proposta, apenas podem ser comercializados os aditivos que tenham autorização (Avicultura Industrial, 18/12/2002). 


\section{REFERENCIAL TEÓRICO}

Neste capítulo, são apresentados os fundamentos teóricos nos quais procura-se explicar o posicionamento da indústria avícola frente às restrições do mercado consumidor europeu. Neste trabalho utiliza-se a teoria da Nova Economia Institucional (NEI) para compreender o ambiente das instituições na União Européia e como elas podem afetar o ambiente institucional brasileiro. Também utiliza-se a teoria da Economia dos Custos de Transação (ECT) para se entender como a indústria avícola está procedendo para satisfazer os clientes europeus e para garantir a qualidade das matérias-primas.

Este capitulo está estruturado da seguinte maneira: primeiro, faz-se uma breve apresentação da Economia dos Custos de Transação, seguida dos Pressupostos Comportamentais e por fim, as principais idéias de Douglas North. Posteiormente, será tratada a integração vertical e os contratos na avicultura. Por último, apresenta-se a fundamentação teórica para os estudos de caso.

\subsection{Nova Economia Institucional}

A Nova Economia Institucional (NEI) é formada por duas correntes complementares: a que estuda o Ambiente Institucional e a que estuda as Instituições de Governança (Economia dos Custos de Transação). A primeira, contendo os estudos liderados por Douglas North, faz análises dos parâmetros macroinstitucionais e a 
segunda, tem Oliver Williamson como precurssor das pesquisas, analisa as microinstituições.

\title{
3.1.1 Economia dos Custos de Transação
}

\begin{abstract}
A teoria da Economia de Custos de Transação (ECT) sustenta que são as características das transações que irão condicionar a forma de governança mais eficiente, ou aquela que se espera como redutora dos custos de transação. Destacam-se as dificuldades de se mensurar os custos de transação e até mesmo de identificá-los adequadamente visto que, diferentemente dos custos de produção física, aqueles não são facilmente separáveis dos custos administrativos da atividade./
\end{abstract}

As estruturas de governança podem ser classificadas em: i) a opção pela compra no mercado; ii) a produção própria, sob a forma hierárquica e iii) a forma híbrida (contratos e a integração vertical). No primeiro caso, a sinalização de preços é suficiente para organizar o mercado com um nível de controle menor. No segundo caso, as transações são conduzidas dentro de um regime de propriedade unificada, pois o comprador e o vendedor são da mesma empresa, e são sujeitos a controles administrativos. A integração vertical será preferivel em situações de alta especificidade de ativos, de maior incerteza e com complexidade contratual. Já nas formas híbridas, ocorrem relações contratuais que preservam a autonomia das partes e instituem salvaguardas específicas às transações. Os contratos apresentam custos associados ao seu desenho, implementação, monitoramento e custos associados à solução de disputas emergentes do descumprimento das relações contratuais estabelecidas (Zylbersztajn, 1995).

\subsubsection{Pressupostos comportamentais}

Custos de transação são custos não ligados diretamente à produção, mas que podem surgir à medida que os agentes se relacionam entre si e problemas de 
coordenação de suas ações emergem (Farina et al, 1997). O conceito de custos de transação é ilustrado por Williamson $(1985$, p.19) como o "equivalente econômico ao atrito no sistema físico".

Williamson (1996) destaca dois pressupostos fundamentais para a compreensão da ECT: os agentes têm racionalidade limitada e são oportunistas, o que leva a contratos incompletos. $O$ oportunismo implica que as partes podem se aproveitar de uma renegociação, agindo aeticamente, impondo, conseqüentemente, perdas a sua contraparte na transação (Farina et al, 1997). O fato de alguns agentes agirem de modo oportunista algumas vezes é suficiente para introduzir custos de monitoramento nos contratos, incluindo, dessa forma, salvaguardas para situações de dependência unilateral (Zylbersztajn, 1995).

Quando a ação oportunista ocorre antes do fechamento do contrato é denominada Seleção Adversa (adverse selection), e quando ocorre após o fechamento do contrato é chamada de Risco Moral (moral hazard). Esses comportamentos são facilitados quando alguma informação estiver incompleta, imperfeita ou assimétrica, opondo-se, dessa forma, a Economia Neoclássica cujo pressuposto é o de que as informações pertinentes aos contratos são sempre perfeitas.

Assim, dado um determinado ambiente institucional, as estruturas de governança serão determinadas pelas características das transações, ou seja, supõe-se que a existência de diferentes estruturas sejam explicadas pelas diferenças básicas nos atributos das transações cujas principais características são: a) especificidade dos ativos, b) freqüência e c) incerteza, descritas a seguir.

\subsection{Ativos específicos}

“Ativos específicos são aqueles que não são reempregáveis a não ser com perdas de valor" (Farina et al, p. 84). Assim, quanto maior a especificidade, menor o 
valor do ativo em outros usos e, portanto, maior o risco envolvido na transação, gerando um aumento no custo final.

Williamson (1996) divide a especificidade em seis tipos: a) locacional (proximidade das firmas de uma mesma cadeia produtiva reduz os custos de transporte e armazenamento); b) física (refere-se ao uso do ativo); c) humana (especialização do capital humano); d) especificidade de marca (refere-se ao montante de capital envolvido para a fortificação de uma marca); e) ativos dedicados (investimento num ativo por um comprador específico) e f) especificidade temporal (período em que se processa a transação). $\mathrm{O}$ referido autor destaca que a especificidade dos ativos somente tem importância quando está em conjunto com racionalidade limitada, oportunismo e incerteza sendo de extrema relevância para a economia dos custos de transação.

Sob a ótica da especificidade de ativos, Williamson (1996) propõe um modelo analítico conhecido como "forma reduzida", que relaciona o grau de especificidade dos ativos envolvidos no custo da governança. Em resposta ao modelo, para níveis de baixa especificidade, a forma de mercado é a estrutura associada ao menor custo de transação. Com o aumento da especificidade ocorre o aumento das dificuldades de o mercado lidar com estas adaptações; o modo híbrido torna-se, assim, mais eficiente com o estabelecimento de incentivos e controles gerados pelos contratos. Na situação mais extrema, o modo hierárquico visa a implementação das adaptações suprido pela organização interna.

\subsection{Freqüência}

A repetição de uma determinada transação é um dos elementos relevantes para a escolha de uma estrutura de governança adequada a essa mesma transação. As transações podem ser ocasionais ou recorrentes. Assim, quanto mais freqüente for uma 
transação, por mais tempo uma estrutura especializada pode se manter, diminuindo seus custos.

Essa repetição possibilita também que as partes adquiram conhecimento umas das outras, o que reduz a incerteza; e que se construa uma reputação em torno de uma marca, o que cria um ativo específico e finalmente, que se crie, em alguns casos, um compromisso confiável entre as partes. O estabelecimento de um compromisso confiável está relacionado com o custo de oportunidade de se realizar uma ação oportunista. Como a transação tem a perspectiva de continuidade, tem como penalidade a interrupção da relação, cujo custo é dado pelo valor presente descontado dos ganhos futuros derivados da transação (Farina et al, 1997).

Baseado nos pressupostos comportamentais de racionalidade limitada $\mathrm{e}$ do oportunismo dos agentes econômicos na análise de contratos, Williamson (1985) relaciona os pressupostos comportamentais em decorrência e as especificidades do ativo com a forma contratual redutora de custos de transação, conforme o modelo apresentado no Quadro 1.

\begin{tabular}{|c|c|c|l|}
\hline \multicolumn{2}{|c|}{$\begin{array}{c}\text { Pressupostos } \\
\text { Comportamentais }\end{array}$} & $\begin{array}{c}\text { Especif. } \\
\text { Ativos }\end{array}$ & \multicolumn{1}{|c|}{ Tipo de Contrato } \\
\cline { 1 - 2 } $\begin{array}{l}\text { Racion. } \\
\text { Limitada }\end{array}$ & Oport. & & \\
\hline 0 & + & + & $\begin{array}{l}\text { planejamento (capacidade de previsão de todos os } \\
\text { problemas potenciais) }\end{array}$ \\
\hline+ & 0 & + & Promessa (baseado na honestidade das partes) \\
\hline+ & + & 0 & mercado (competição) \\
\hline+ & + & + & contrato ou integração vertical \\
\hline
\end{tabular}

Quadro 1 - Relação entre comportamento dos indivíduos, especificidade dos ativos e tipo de contrato esperado.

Fonte: Williamson $(1985, \mathrm{p} .31)$ 
No primeiro caso, considerando-se que os agentes tenham racionalidade total, mas são oportunistas e os ativos sejam específicos, sugere-se o planejamento, em que todos os aspectos do contrato podem ser previstos durante o desenho do mesmo. Nesse caso, os contratos seriam completos e efetivos, já que os agentes seriam totalmente racionais e poderiam prever todas as situações ex-ante. Na segunda situação, considerando que não haja oportunismo, a racionalidade seria limitada e tem-se a presença de ativos específicos e a simples promessa das partes seria suficiente. No terceiro caso, estão presentes tanto a racionalidade limitada como o oportunismo dos agentes econômicos, porém, os ativos podem ser livremente deslocados entre suas utilizações e o mercado arbitraria as disputas. Finalmente, na situação com racionalidade limitada, oportunismo e especificidade dos ativos, as relações contratuais seriam aquelas minimizadoras dos custos envolvidos. Zylbersztajn (1995, p. 141) complementa que a integração vertical "implicará em prêmios superiores sobre a organização via mercado sempre que em presença de níveis elevados de especificidade de ativos".

\subsection{Incerteza}

A impossibilidade de se prever eventos futuros aliado à racionalidade limitada e ao oportunismo dos agentes econômicos faz com que os contratos fiquem incompletos, resultando em incertezas. Tais incertezas podem ser de três tipos: a) risco (refere-se a uma variância de uma dada distribuição de probabilidade); b) incerteza (desconhecimento de eventos futuros) e c) incertezas quanto ao aspecto informacional relativa a um contrato (informação incompleta e assimétrica) (Farina et al, 1997).

Sob a ótica da incerteza, a forma de governança esperada emerge da confluência do nível de incerteza com o de especificidade dos ativos. Williamson (1996) afirma que para baixos níveis de especificidade a forma de governança via mercado não será afetada pelo nível de incerteza. Para níveis intermediários de especificidade, os contratos são a forma de governança minimizadora de custos, pois adaptações não podem ser obtidas a custo zero no mercado. Na medida em que a especificidade 
aumenta, as formas de governança de mercado e híbridas perdem sua capacidade de organização, quando comparadas com a forma hierárquica. Dessa forma, em níveis mais específicos de ativos, a forma hierárquica permite melhores resultados a um custo menor.

Dessa forma, a incerteza, a frequência juntamente com a especificidade dos ativos, permitem o desenho de uma estrutura de governança com o objetivo de atenuar os custos de transação associados a essa mesma transação (Farina et al, 1997).

\subsection{Ambiente institucional}

North (1990) destaca o papel do ambiente institucional como importante variável redutora de custos de transação, a exemplo da garantia de direitos de propriedade Com o objetivo de analisar o papel das instituições, essa corrente vem trilhando dois caminhos: a)investigar os efeitos de uma mudança no ambiente institucional sobre o resultado econômico e b) teorizar sobre a criação das instituições (Farina et al, 1997).

As instituições estabelecem as "regras do jogo" numa sociedade (North, 1992). Mais precisamente, “as instituições consistem as restrição informal (sanções, tabus, costumes, tradições e códigos de conduta) e as regras formais (constituição, leis, direitos de propriedade)" (North, 1991, p. 97). Coase (1937) destaca que só se obtêm os resultados neoclássicos de mercados eficientes quando não há custos de transação. Quando os custos de transação são consideráveis, as instituições passam a ter importância no processo.

As organizações são os jogadores e compõem-se de grupos de indivíduos dedicados a alguma atividade executada com determinado fim. As limitações impostas pelo contexto institucional definem o conjunto de oportunidades e, portanto, os tipos de 
organizações que serão criadas (North, 1992) ${ }^{14}$. Os agentes de mudanças são os empresários, políticos ou agentes econômicos, aqueles que decidem nas organizações. Já as mudanças de regras formais incluem, entre outras, reformas legislativas, como a aprovação de novas leis; mudanças jurídicas resultantes de jurisprudência que altera os institutos do direito; mudanças de normas e diretivas por parte dos órgãos reguladores; e mudanças de dispositivos constitucionais, os quais alteram as regras que ditam a elaboração de outras normas (North, 1992).

Segue ainda que as mudanças institucionais resultantes da alteração de restrições informais como as normas, convenções ou padrões individuais de honestidade, ocorrem muito mais gradativamente e às vezes de forma inconsciente, à medida que as pessoas desenvolvem padrões alternativos de comportamento condizentes com sua nova avaliação dos custos e benefícios de uma transação.

Dado um conjunto de instituições numa sociedade, Alston (1998) destaca que o pretendente irá fazer contratos com os ofertantes de matérias-primas para minimizar a soma dos custos de transação e de transformação. Tem-se como resultado uma variedade de contratos em que ocorre a divergência entre os componentes do custo de transação e o de produção.

O ambiente institucional é visto como o locus de parâmetros de deslocamento, que interferem na decisão sobre a forma organizacional de produção a ser utilizada (Zylbersztajn, 1995). Como exemplo cita-se a mudança do ambiente institucional ocorrida na Europa em função das exigências dos consumidores com a segurança do alimento consumido e como isso desencadeou uma série de mudanças tanto nas instituições européias como nas brasileiras, na forma de leis, normas, diretivas, etc.

${ }^{14}$ NORTH, D.C. Custos de transação, instituições e desempenho econômico. Ensaio e Artigos. s.l.: Instituto Liberal, 1992. 
tanto nas instituições européias como nas brasileiras, na forma de leis, normas, diretivas, etc.

Os custos de transação surgem ao se mensurar as múltiplas dimensões valorizadas incluídas na transação,e quando na execução contratual a informação tenha custos elevados, podendo ser imperfeita. As instituições e organizações eficazes podem reduzir os custos de cada transação, de forma a obterem uma parcela maior dos ganhos potenciais de cada interação humana (North, 1992).

Portanto, as instituições podem ser ineficientes quando os custos de transação dos mercados políticos e econômicos, juntamente com o modelo subjetivo dos atores, não induzem o sistema econômico a caminhar em direção de resultados mais eficientes (North, 1990).

\subsection{Integração vertical}

Canever et al (1998) destacam que a coordenação da atividade avícola é realizada por meio da integração vertical com a horizontal, em que os frigoríficos organizam e promovem as transações desde as fases de produção dos insumos até a distribuição de produtos finais, nos mercados consumidores. Conforme Reis (1999), as integrações podem ser realizadas por meio da expansão e do crescimento de uma firma, ou por união de firmas com outras similares (horizontal) ou com outras que operem em segmentos diferentes de mercado (vertical). Pode ocorrer ainda uma mistura das duas formas de integração, denominada mista ou composta, com a presença de elementos verticais e horizontais, de níveis e/ou funções.

Para os autores Carlton \& Perloff (1994) existem pelo menos seis vantagens quando uma firma se integra verticalmente: i) a firma pretende diminuir os custos de transação; ii) a firma pretende se assegurar da oferta dos "insumos-chaves"; 
aumentar ou criar poder de mercado, e finalmente, vi) não permitir que outra firma integrada verticalmente, (com poder de mercado) elimine o seu poder de mercado.

A avicultura de corte no Brasil baseou-se num modelo de produção que consistia na integração vertical, com geralmente o pequeno produtor versus a grande agroindústria, com o uso intensivo de inovações tecnológicas modernas e concentrada, basicamente, na região Sul do país. Fernandes Filho e Queiroz (2001) destacam as principais características desse modelo de produção: presença de muitos pequenos produtores integrados; uso de mão-de-obra familiar; preocupação dos produtores com a geração de emprego e renda para os familiares; presença de grande número de contratos; dependência de assistência técnica, financeira e tecnológica da integradora; baixa capacidade de alojamento dos aviários e heterogeneidade tecnológica.

Os autores Kohols \& Wiley ${ }^{15}$ (1955), Seaver ${ }^{16}$ (1957) e Scherer $^{17}$ (1970) citados por Marques (1991), afirmam que as empresas integram-se para a aumentar sua eficiência e que isso pode ocorrer em função de algumas condições: i) redução nos custos provenientes de ganho de escala; ii) evitar custos associados com o mecanismo de economia de escala; e iii) permitir à própria empresa apropriar-se de ganhos que de outra forma seriam auferidos por outros intermediários. Pelo lado dos produtores, esses integram-se pelo fato de: i) neste sistema a incerteza ser reduzida quanto ao preço que o produtor receberá pela sua produção; e ii) a empresa integradora, por ter interesse na qualidade e homogeneidade da produção, fornecer assistência técnica de qualidade mais alta que a tradicionalmente oferecida pelos órgãos públicos, elevando-se os índices de produtividade técnica dos produtores.

\footnotetext{
${ }^{15}$ KOHLS, R.L.I.; WILEY, J.W. Aspects of multiple-owner integration in the broiler industry. Journal of Farm Economics, v.37, n.1, p.81-89, 1985.

${ }^{16}$ SEAVER, K.S. Anapraisal of vertical integration in the broiler industry. Journal of Farm Economics, Cambridge, v.39, n.5, p.1487-1499, 1957.

${ }^{17}$ SCHERER, F.M. Industrial market structure and economic performance. Chicago: Rand McNally College Publishing, 1970.
} 
Roy $(1972)^{18}$, citado por Araújo (1996) caracteriza a integração vertical como a combinação de dois ou mais estágios sucessivos de produção e/ou distribuição sob a propriedade ou controle da firma. Nesse caso, a integração pode ocorrer de duas maneiras: "para frente", quando uma firma move-se para o estágio de produção subseqüente; e "para trás", quando uma firma passa a produzir também a matéria-prima ou os insumos. Canever et al (1997, p.31) afirmam que a "eficiência da avicultura é dependente da coordenação integrada, pois as respostas aos estímulos dos consumidores são feitas mais rapidamente, visto que isso consegue amenizar os problemas oriundos da quase total impossibilidade de estocagem das aves, tanto vivas como abatidas".

Para Azevedo (2000, p.76-7),

"enquanto uma estratégia empresarial, a integração vertical revela um trade-off fundamental. De um lado, ao integrar-se verticalmente, uma empresa adquire maior controle da cadeia produtiva, o que lhe permite a adoção de ações voltadas à redução de custos e/ou de ação estratégica contra rivais, ou, ainda, de ações que visem a exploração do mercado de consumo do produto final. De outro, a integração vertical desvia os esforços gerenciais da empresa de seu foco de negócios, elevando custos burocráticos e prejudicando a estrutura de incentivos característica dos mercados".

\subsection{Contratos na avicultura}

O sistema integrado sob contratos surgiu paralelamente à grande modernização da avicultura como um processo de mudança nas estratégias organizacionais, disseminando-se rapidamente. Atualmente, a avicultura brasileira está

\footnotetext{
${ }^{18}$ ROY, E.P. Contract farming and economic integration. Danville: The Interstate Printer, 1972.
} 
fortemente baseada no sistema de produção integrada, cujas atividades dos produtores são regidas por contratos firmados com a indústria (Richetti \& Santos, 2000).

Lopes (1992, p.14) afirma que "a integração por meio de contratos consiste em transações firmadas entre agricultores e companhias ou negociantes, especificando uma ou mais condições e ou, a comercialização de determinado produto". $\mathrm{O}$ autor conclui que os contratos de integração garantem uma certa estabilidade de renda aos produtores integrados, remunerando todos os fatores de produção e ainda propiciando uma renda residual a eles.

Diversos têm sido os arranjos contratuais estabelecidos entre produtores e a agroindústria brasileira visando a redução dos custos de transação. Marques (1991) analisou os contratos estabelecidos entre produtores de aves e frigoríficos, sistema amplamente difundido, principalmente na região Sul do país. $\mathrm{O}$ autor identifica que os objetivos dessa relação seriam principalmente os de reduzir a incerteza quanto ao preço e de garantir à indústria a qualidade e homogeneidade da produção requerida.

Em outro estudo, Araújo (1996) refere-se aos diferentes estágios produtivos do setor avícola, coordenados como na verticalização, mas que se diferem pelos contratos firmados entre a indústria e os produtores avícolas na fase de criação de frangos de corte.

O contrato de produção tem-se apresentado como componente básico do processo de integração definido como "o relacionamento e a dependência direta entre produção agropecuária e empresa integradora, que pode ser formulado explicitamente por meio de contratos escritos ou oralmente. O conteúdo destes contratos ou pactos, formulados juridicamente ou não, diz respeito substancialmente à exclusividade na aquisição dos insumos por parte do produtor rural, ao padrão tecnológico e ao manejo a ser posto em prática sob orientação e assistência técnica da empresa e, 
fundamentalmente, à exclusividade e garantia da produção agropecuária por parte da empresa integradora" (Sorj et al, 1982, p.42).

Dependendo do contrato, a remuneração é feita conforme o desempenho dos lotes, no que se refere à mortalidade, taxa de conversão e ganho diário (Marques \& Aguiar, 1989). Sob essa ótica, os modernos processos de criação e industrialização associados à melhoria genética das aves têm levado a excelentes índices. Marques (1991) afirma que os tipos de contratos podem variar, mas a característica comum entre eles diz respeito ao produtor, que é apenas fornecedor de mão-de-obra e infraestrutura, tendo pouca ou nenhuma atuação nas decisões técnicas e administrativas. Na realidade, ele recebe um "pacote" pronto, sem nenhuma possibilidade de mudança tecnológica.

\subsection{Estudo de caso}

De modo geral, o estudo de caso é aplicável quando se deseja obter generalizações analíticas e não estatísticas, que possam contribuir para um certo referencial teórico. A pesquisa por meio de estudos de caso tem sido enquadrada no grupo de métodos denominados qualitativos, que se caracteriza por um maior foco na compreensão dos fatos do que propriamente na sua mensuração. Dessa forma, contrastase com os métodos quantitativos, que se preocupam mais em mensurar fenômenos e são aplicados a amostras mais extensas (Lazzarini, 1997).

Para este trabalho, optou-se pela análise de estudos de caso múltiplos, cuja vantagem reside no fato de esses proporcionarem evidências inseridas em diferentes contextos, o que acaba tornando a pesquisa como um todo mais robusta (Lazzarini, 1997). Entretanto, as principais limitações de tais estudos de caso são a subjetividade de análise e a impossibilidade de generalizações das conclusões (Yin, 1989). 


\section{MATERIAL E MÉTODOS}

Neste capítulo serão apresentados os aspectos metodológicos propostos para analisar-se o posicionamento da indústria avícola frente às restrições do mercado consumidor europeu. Pretendeu-se pesquisar empiricamente, por meio de questionário, $o$ relacionamento das empresas avícolas exportadoras com seus respectivos clientes, fornecedores de matéria-prima e de premix e posteriormente complementar o trabalho com estudos de caso. Por meio das respostas obtidas, as empresas foram distribuídas em grupos, com base nas situações específicas de mercado e características diferenciais. A escolha das empresas para os estudos de caso depende dessa distribuição para que a análise, então, fosse feita com cada uma.

O total de empresas avícolas selecionadas que exportam para a União Européia soma 60 , mas somente 37 dessas possuem abatedouro. Após a tabulação dos dados dos questionários, as empresas foram distribuídas em grupos e, para os casos representativos, foi realizado estudo de caso.

Em seguida, serão apresentadas as definições das variáveis que fizeram parte do questionário e dos estudos de caso, também o referencial teórico e os objetivos propostos. Por fim, será exposta a técnica utilizada para o tratamento estatístico dos dados obtidos. 


\subsection{Obtenção dos dados}

Foram aplicados questionários às empresas avícolas que tinham Sistema de Inspeção Federal (SIF) ${ }^{18}$, e que eram habilitadas a exportar para a União Européia. Destaca-se que as empresas habilitadas não são necessariamente todas que possuem SIF - as empresas avícolas somam 160 (Apêndice 1) e para se habilitar, a empresa precisa seguir uma série de normas e critérios. É importante ressaltar que a lista das empresas habilitadas para exportar carne de frango para a UE soma 60 empresas (Apêndice 2), contando as que possuem cutting house, abatedouros e câmeras frias. No entanto, para este trabalho, está-se considerando somente as empresas que possuem abatedouro para frangos de corte (SH), por fazerem parte de um sistema integrado e por isso, terem maior influência na cadeia.

As empresas avícolas que exportam para a União Européia estão localizadas nos seguintes estados: São Paulo, Paraná, Santa Catarina, Rio Grande do Sul, Minas Gerais, Goiás, Mato Grosso e Mato Grosso do Sul com 3, 9, 12, 8, 1, 1, 1, 2 empresas respectivamente, totalizando 37 (Apêndice 3). Dessas, observou-se que muitas tinham filiais, o que fez com que recebessem vários questionários. Novamente reagrupadas, essas empresas finalmente, somaram 17 (Apêndice 4). Esses dados foram obtidos junto ao DIPOA/MAPA, por e-mail.

Os questionários foram enviados às 17 empresas avícolas por e-mail em maio de 2003, após contato por telefone. Em duas semanas foram recebidos somente 5 . Com novas ligações mais 3 questionários foram devolvidos. Dessa forma, houve devolução de $47,05 \%$ dos questionários enviados, ou seja, 8 questionários. Dentre os principais entraves para a maximização do número de questionários devolvidos, pode-se destacar a falta de tempo para preenchê-lo como também, o fato de terem sido enviados

\footnotetext{
${ }^{18}$ Para mais informações a Instrução para procedimentos operacionais do Serviço de Inspeção Federal (padronização de critérios) está disponível em: http://www.agricultura.gov.br/sda/dipoa/criterios.lttm (10 jul. 2003)
} 
questionários oriundos de outras instituições e a indisposição do questionado propriamente dita. A empresa que devolveu o questionário será chamada por uma letra (A, B, C, D, E, F, G e H) com o intuito de preservar a sua identidade.

Após a tabulação dos dados do questionário, apresentam-se as seguintes situações específicas entre os fornecedores de grãos e a empresa avícola. A Empresa $\mathrm{A}$ comprava via mercado; a Empresa $\mathrm{C}$ comprava via mercado e com fornecedor cadastrado; a Empresa H comprava grãos por meio de contratos com cooperativas e finalmente, a empresa $\mathrm{F}$, que comprava grãos com contrato junto aos integrados. Portanto, as empresas A, C e H são as escolhidas para os estudos de caso deste trabalho, pois a empresa $\mathrm{F}$ não estava com disponibilidade de recurso pessoal na data pretendida para realizar o estudo de caso.

As entrevistas às empresas $\mathrm{F}$ e $\mathrm{H}$ ocorreram no final de julho de 2003. A entrevista à empresa C ocorreu no início de agosto de 2003. As entrevistas foram gravadas e, posteriormente, transcritas.

\subsection{Definição das variáveis}

Serão apresentadas, a seguir, as definições das variáveis utilizadas no questionário e, posteriormente, as do estudo de caso. Assim, no questionário, foram mantidos 4 eixos principais de questões, a saber: produção, relações da empresa com os clientes europeus, com os fornecedores de matéria-prima e de premix. Optou-se por questões fechadas, em que o entrevistado pode escolher uma ou algumas das alternativas dentro das fornecidas. $\mathrm{O}$ questionário e o roteiro das entrevistas podem ser vistos nos Apêndices 5 e 6.

Com o objetivo de obter-se as informações à respeito dos consumidores europeus, no questionário, perguntou-se sobre os clientes de cada empresa. Todavia, estes consumidores representam clientes para as empresas e por isso em vez de utilizar- 
se o termo "consumidor", utilizou-se o termo "cliente". Outro esclarecimento deve-se ao fato de terem sido utilizados nas perguntas do questionário, a situação antes e depois dos problemas ocorridos na Europa como o mal da vaca louca, em 1996. Esse é um marco de fundamental importância no que se refere às questões relativas à preocupação da segurança do alimento por parte do consumidor europeu. Portanto, para garantir a qualidade e a especificidade das matérias-primas exigidas pelo cliente, a empresa toma algumas precauções como, por exemplo, contratos mais específicos com seus fornecedores.

Outro esclarecimento importante refere-se aos países de origem dos clientes das empresas avícolas aos quais exportam frango. Na questão de número dois do questionário pergunta-se quais são os países de origem desses clientes europeus. Observa-se que nesses termos, está-se considerando não somente os países membros da União Européia, mas também, todos os novos membros e os candidatos. Por isso, na análise dos dados no item 5.3.2 foram consideradas as respostas dos países que fazem parte da Europa com um todo apesar de este trabalho enfocar a legislação vigente com relação à União Européia.

\subsubsection{Variáveis do questionário}

\subsubsection{Produção}

Essa parte do questionário é composta somente por 1 pergunta referente à produção da empresa, em que o entrevistado preencheu as lacunas com os referidos valores em dólares.

Pretende-se, com essa variável conhecer a estrutura produtiva da empresa, a produção total, as exportações de todos os destinos e o volume exportado para a União Européia, no período de 1996-2002. Optou-se por esse período por 
representar relevância para o setor como um todo, com o crescimento das vendas para esse mercado devido aos problemas ocorridos na Europa, como a doença da vaca louca.

\subsubsection{Relacionamento da empresa com os clientes europeus}

Essas variáveis foram utilizadas com o intuito de se retratar como a empresa avícola se relaciona com seus clientes europeus, quais são suas exigências e quais as medidas adotadas pela empresa para atender cada cliente. Observa-se que as questões deste eixo foram preenchidas baseando-se na definição dos tipos de clientes da questão anterior de modo que cada alternativa pudesse se referir a cada um dos clientes simultaneamente. Esse eixo foi dividido em seis variáveis, explicadas a seguir:

a) segurança do alimento: pretende-se captar a opinião da empresa no que se refere ao nível de preocupação dos clientes europeus em relação à segurança do alimento. Nessa questão, a empresa definiu quais os seus tipos de clientes (de A a F), como rede de supermercado, rede de restaurante, atacadista, distribuidor, etc e, posteriormente, assinalando numa escala de 0 a 4, o nível de preocupação de cada cliente. Dessa forma, consegue-se verificar, em média, o quanto cada cliente está preocupado. A definição dos tipos de clientes será utilizada nas questões seguintes para que a pessoa representando a empresa não necessitasse preencher várias vezes o mesmo campo;

b) programas de qualidade: objetiva-se saber quais os programas de qualidade que cada cliente exige, bem como maiores detalhes sobre o sistema de rastreabilidade. Dessa forma, tem-se uma maneira de avaliar o comportamento da empresa frente às exigências e seus clientes;

c) exigências: nessa questão, pretende-se identificar quais são as principais exigências dos clientes da empresa em relação à matéria-prima, conforme proposto nos objetivos deste trabalho;

d) opinião da empresa: essa questão avalia a preocupação da empresa em relação às exigências dos clientes, abordada nas duas questões anteriores, verificando se essas 
exigências revelam a preocupação dos consumidores ou representam barreiras nãotarifárias. $O$ entrevistado marcou a opção desejada com um X em sim ou não.

e) medidas adotadas: avaliam-se quais as medidas que a empresa adotou para atender seus clientes. Essa questão analisa também o comportamento adotado pela empresa frente às exigências impostas.

f) atuação do setor público: pretende-se, com essa variável, captar o que a empresa está demandando do setor público objetivando o crescimento e desenvolvimento do setor avícola.

\subsubsection{Relacionamento da empresa com os seus fornecedores de matéria-prima}

Esse eixo do questionário engloba quatro questões que se referem ao relacionamento da empresa com seus fornecedores de matéria-prima, a saber: frango e grãos. Pretende-se verificar se a especificidade dos ativos está mudando as formas contratuais e também, atingir parte do objetivo geral deste trabalho, que é o de se verificar as mudanças contratuais ocorridas entre a indústria avícola com o produtor de grãos, devido às exigências do consumidor europeu quanto à qualidade do alimento.

a) matéria-prima frango: com essa questão, objetivou-se conhecer de como a empresa adquiria a matéria-prima frango, a saber: via compra no mercado, via contratos, ou de outro modo, antes de 1996. Com isso, consegue-se captar como era a estrutura de governança da empresa;

b) matéria-prima frango atualmente: pergunta-se como a empresa adquire atualmente essa matéria-prima. Assim, pode-se fazer uma análise da mudança da estrutura de governança devido aos problemas da doença da vaca louca, bem como verificar-se qual a estrutura vigente;

c) fornecedor de grãos: a idéia principal dessa questão é captar qual era a estrutura de governança adotada pela empresa com seu fornecedor de grãos, antes de 1996;

d) fornecedor de grãos atualmente: pretende-se verificar a estrutura de governança adotada pela empresa com seu fornecedor de grãos, atualmente, assim como as 
respectivas mudanças que estão ocorrendo e verificar se houve aumento na especificidade dos ativos.

\subsubsection{Relacionamento da empresa com os seus fornecedores de premix}

Esse eixo do questionário, composto por duas questões, tem por objetivo verificar se houve mudanças contratuais ocorridas entre a empresa e o fornecedor de premix.

a) fornecedor de premix: objetivou-se verificar qual era a estrutura de governança adotada pela empresa com seu fornecedor de premix, antes de 1996;

b) fornecedor de premix atualmente: objetiviu-se verificar a estrutura de governança adotada pela empresa com seu fornecedor de premix, atualmente. Dessa forma, pretende-se verificar as mudanças na estrutura de governança, bem como se contratos mais específicos estão sendo feitos entre as partes.

\subsubsection{Variáveis dos estudos de caso}

As variáveis dos estudos de caso dividem-se em quatro eixos: produção; relações da empresa com seus clientes europeus; com seus fornecedores de matériaprima e de premix. Cada um desses eixos será definido a seguir.

\subsubsection{Produção}

Esse eixo está sub-dividido em quatro perguntas com o objetivo de ter-se mais conhecimento a respeito de dados pertinentes à produção da empresa.

a) desde quando a empresa exporta para a União Européia: ao se perguntar desde quando a empresa atua no mercado europeu esperava-se verificar as mudanças que ocorreram na empresa e quais ela considerou como mais importantes. Pretende-se saber 
também desde quando ela está preocupada em atender seus clientes, com o complemento de outras perguntas posteriormente;

b) qual a ordem de importância da UE na lista dos clientes: é importante saber a ordem de importância desse cliente como medida de atendimento de suas exigências, qual a relevância do mesmo para a empresa em atendê-lo;

c) por que a empresa optou por exportar para esse mercado: para poder detectar-se se a empresa tornou-se obrigada a exportar para a UE, porque outros mercados já estavam saturados, ou, porque tornou-se um mercado com especificações muito restritas e que qualquer empresa não estaria apta em atendê-los (razões logísticas, etc);

d) a produção exportada para a UE no período de 1996-200,2 em US\$: é relevante ter-se o conhecimento da produção exportada das empresas, pois nos questionários não conseguiu-se captar essa variável devido ao não preenchimento dessa questão, pela maioria das empresas.

\subsubsection{Relacionamento da empresa com seus clientes europeus}

Nesse eixo estão oito questões que referem-se ao relacionamento da empresa com seus clientes europeus.

a) explique a função do cliente europeu com o qual sua empresa trabalha (processador, distribuidor, trader). Objetivou-se conhecer um pouco mais sobre a função desempenhada por cada tipo de cliente, bem como suas características;

b) desde quando o cliente passou a exigir que a empresa implantasse programas de qualidade. Esta pergunta tem por objetivo saber se realmente a preocupação do consumidor se acentuou a partir de 1996, quando a doença da vaca louca se manifestou em humanos;

c) desde que ano a empresa implantou o Programa EFSIS, se não implantou, ainda não foi exigido. O Serviço Europeu de Inspeção e Segurança do Alimento (EFSIS) é um serviço de inspeção, baseado no Reino Unido, que abrange todos os tipos de alimentos, prestando aos varejistas, fabricantes e fornecedores, serviços de consultoria e 
certificação para as suas operações industriais, baseado nas normas ISO 9000 e HACCP. Por isso, essa pergunta tem por objetivo esclarecer se os clientes europeus estão exigindo essa certificação ou se exigiram e a empresa ainda não o fez;

d) como é o sistema de rastreabilidade implantado (por lote, por origem, por data de abate, por tipo de destino de cliente, etc.: pelo fato de o sistema de rastreabilidade não ser um programa oficial no Brasil, mas exigido pelos clientes europeus, torna-se interessante explorar como esse sistema foi implantado em cada empresa entrevistada;

e) além das exigências (GGM; subprodutos de origem animal; aditivos, antibióticos; promotores de crescimento) existem outras que os clientes europeus passarão a exigir em breve: torna-se importante saber as futuras demandas dos clientes para que a indústria avícola tenha tempo suficiente para se adaptar a elas;

f) em relação às medidas que a empresa adotou para atender seus clientes, elas foram adotadas somente para atender a solicitação dos clientes europeus ou também para atender outros clientes: essa questão é interessante, em termos de esclarecimento, se as empresas entrevistadas tomaram determinadas medidas com o objetivo único de atender aos clientes europeus ou a outros mercados também;

g) existem outras medidas importantes que a empresa adotou para satisfazer os clientes no que diz respeito à segurança dos alimentos fabricados: nessa questão deseja-se saber se existem outras medidas importantes tomadas pelas empresas, para atenderem os clientes europeus que não foram citados no questionário;

h) a análise das especificidades do frango (inteiro e em cortes) exportado é realizada na UE? A empresa acha que essa análise deveria ser feita no Brasil, sob a supervisão do MAPA ou em laboratórios credenciados do MAPA: verificou-se que $100 \%$ das respostas afirmaram que a atuação do setor público na solução das exigências dos clientes europeus poderia ser com o credenciamento de laboratórios de análise de resíduos. Portanto, com essa pergunta objetivou-se aprofundar um pouco essa questão. 


\subsubsection{Relacionamento da empresa com seus fornecedores de matéria-prima}

As questões que se referem ao relacionamento entre as empresas e seus fornecedores de matéria-prima tratam especificamente de grãos, com duas perguntas.

a) como era a relação contratual entre a empresa e seu fornecedor de grãos, antes de 1996 (mal da vaca louca) e como é atualmente: pretende-se captar com era o relacionamento da empresa com seu fornecedor de grãos antes de ocorrerem várias mudanças na legislação européia, em função do aparecimento da doença da vaca louca. Dessa forma, objetivou-se verificar com mais detalhes as características dessa estrutura de governança, e como é essa relação atualmente. Pretende-se ainda constatar se a especificidade dos ativos está mudando as formas contratuais devido às exigências do consumidor europeu e como ocorreu esse processo;

b) quais as medidas adotadas pela empresa quando o governo decretou a liberalização da safra de grãos transgênicos 2002/03 no Brasil (porque a UE proíbe seu uso na ração): essa questão torna-se de extrema relevância por tratar de um assunto muito recente. Umas das restrições da UE diz que os grãos utilizados na composição da ração dos frangos não podem ser transgênicos. Até março de 2003, estava proibido no Brasil a produção e comercialização de grãos transgênicos. Sob essa legislação, a indústria avícola estava assegurada da ausência dos mesmos. Dessa forma, espera-se que a empresa tenha adotado algumas medidas de garantia e origem da matéria-prima para o cumprimento das exigências de seu cliente.

\subsubsection{Relacionamento da empresa com seus fornecedores de premix}

Finalmente, esse eixo, com somente uma pergunta, trata do relacionamento das empresas com seus respectivos fornecedores de premix.

a) como era a relação contratual entre a empresa e o fornecedor de premix antes de 1996 (mal da vaca louca) e como é atualmente: da mesma forma como buscou-se 
verificar a característica da estrutura de governança entre a empresa e o fornecedor de grãos, objetivou-se, nessa questão, saber como é a relação com seus fornecedores de premix.

\subsection{Análise dos dados}

A análise dos dados dos questionários seguirá a metodologia proposta por Barbetta (2002) e Gil (1991). Barbetta (2002) sugere que depois de os dados terem sido coletados, é necessário organizá-los para facilitar a análise. Por isso, é comum armazená-los em matrizes ou quadros, onde cada coluna se refere a uma variável e cada linha a um respondente, subdividido por cada cliente. Esses dados podem ser vistos nos Apêndices 7, 8, 9, 10 e 11. Gil (1991) sugere que os dados brutos sejam codificados, ou seja, transformados em símbolos para que possam ser tabulados.

Depois da tabulação, Barbetta (2002) introduz técnicas que permitem organizar, resumir e apresentar esses dados de forma que se possa interpretá-los conforme os objetivos propostos - esse tratamento é chamado de estatística descritiva. Segue ainda que após os dados adequadamente resumidos e apresentados em tabelas e gráficos, pode-se observar determinados aspectos relevantes - chamada de análise exploratória dos dados.

A análise dos dados dos questionários desse trabalho foi feita utilizandose a análise univariada. $O$ primeiro passo para se entender o comportamento de uma variável, em relação aos elementos observados, é a construção de uma distribuição de freqüências ${ }^{19}$.

19 Essa distribuição compreende a organização dos dados de acordo com as ocorrências dos diferentes resultados observados. Para a construção de uma distribuição de freqüências com dados de uma variável qualitativa, é necessário somente contar a quantidade de resultados observados em cada categoria, podendo-se também apresentar uma medida relativa de frequêencia. Estas percentagens são obtidas dividindo-se a frequêencia de cada categoria pelo número total de observações e, em seguida, multiplicando-se por 100 . 
Nos estudos de caso, cada questão será discutida depois de se mostrar as respostas das três empresas entrevistadas. 


\section{RESULTADOS E DISCUSSÃO}

Nesse capítulo serão apresentados os resultados dos questionários feitos com as oito empresas avícolas exportadoras para a União Européia e, posteriormente, os três estudos de caso. Destaca-se que as oito empresas que responderam ao questionário serão nomeadas por uma letra, se extendendo de $\mathrm{A}$ até $\mathrm{H}$, com o objetivo de se preservar a identidade das mesmas.

\subsection{Esclarecimentos iniciais}

\subsubsection{Problemas intrínsecos à pesquisa via questionários}

É importante ressaltar algumas distorções que podem ter havido nas respostas dos questionários em função do próprio método de pesquisa conduzido, bem como do modelo das questões vinculadas. Como o questionário envolvia questões pertinentes à produção, ao relacionamento da empresa com seus clientes europeus, a programas de qualidade, às exigências de seus clientes, aos fornecedores de matériaprima (frango, grãos e premix) as pessoas que responderam o questionário obviamente não pertenciam a todos esses setores simultaneamente, pois o questionário foi enviado a pessoas que trabalham diretamente com as exportações para a União Européia. Por isso, o questionado precisava se deslocar para outros setores ou preencher uma parte e outra pessoa o terminava. No entanto, das pessoas que responderam, pode-se observar que elas entraram em contato com os responsáveis pelos outros setores para obter as respostas que não estariam ao seu alcance. 
Além disso, cita-se a questão relativa ao preenchimento dos dados da produção, exportação total e para a UE, no período 1996-2000, em dólares, em que observaram-se vários cenários: 4 empresas não preencheram o quadro, 1 empresa preencheu os dados de 2001 e 2002, outra somente de 2002, outra de 2003 e, finalmente, apenas uma preencheu os dados completos. Ressalta-se ainda, que foi solicitado para que as empresas revelassem valores em dólar, por ano, e foram obtidas algumas respostas em unidades diferentes: toneladas, reais e produção e exportações mensais. Isso causou uma preocupação pelo fato de não ser possível apresentar neste trabalho um quadro mais detalhado. Para resolver esse problema, nos estudos de caso perguntou-se novamente se haveria disponibilidade destes dados. Das 3 empresas entrevistadas, uma se reservou; outra empresa enviou via e-mail os dados e finalmente, a terceira dispõe somente os valores das exportações totais em reais, respectivos aos anos de 2001 e 2002.

\subsection{Produção e exportação}

Os dados dessa questão referem-se à produção, exportação total e para a União Européia, em dólares, no período 1996-2002. Infelizmente, esses dados não foram obtidos com êxito, conforme mencionado anteriormente (Apêndice 7). Devido a esse fato, neste trabalho se tomarão como base os dados da Associação dos Produtores e Exportadores de Frangos (ABEF), quanto às exportações para a União Européia, já explicados no capítulo 2. Nos estudos de caso essa questão será novamente levantada.

\subsection{Preocupação dos clientes em relação à segurança do alimento}

\subsubsection{Segurança dos alimentos}

Com essa questão pretende-se medir o nível de preocupação dos consumidores europeus em relação à segurança dos alimentos. Devido ao fato de este trabalho ser realizado somente com dados coletados no Brasil - questionários aplicados às empresas avícolas que exportam para o mercado europeu e complementado com estudos de caso - fez-se a avaliação dessa preocupação utilizando-se as respostas dos clientes mencionados pelas empresas. 
Ressalta-se que a definição de alguns dos tipos de clientes das empresas identificados como indústria, distribuidor, atacadista, processador, supermercado, restaurante, traders e geral será dada no próximo tópico, nos estudos de caso.

Tabela 3. Tipos de clientes e seu nível de preocupação com a segurança do alimento ${ }^{20}$.

\begin{tabular}{lccc}
\hline tipos de clientes & $\begin{array}{l}\text { frequência } \\
\text { clientes }\end{array}$ & $\begin{array}{l}\text { Porcentagem de } \\
\text { cada cliente (\%) }\end{array}$ & $\begin{array}{l}\text { preoc.média por tipo de } \\
\text { cliente }\end{array}$ \\
\hline Indústria & 1 & 2,44 & 4,00 \\
Distribuidor & 17 & 41,46 & 3,47 \\
Atacadista & 5 & 12,20 & 2,80 \\
Processador & 6 & 14,63 & 3,50 \\
Supermercado & 1 & 2,44 & 4,00 \\
Restaurante & 1 & 2,44 & 4,00 \\
Traders & 3 & 7,32 & 4,00 \\
Geral & 7 & 17,07 & 3,57 \\
\hline
\end{tabular}

Fonte: Dados da pesquisa.

Legenda: $0=$ nenhum nível de preocupação; 1 =baixo nível de preocupação; $2=$ =édio nível de preocupação; 3=alto nível de preocupação; 4=altíssimo nível de preocupação.

Conforme a Tabela 3, o nível de preocupação dos clientes em relação à segurança do alimento, mostra-se altíssimo (média 4) em 4 tipos de clientes: indústria, supermercado, restaurante, traders. Por outro lado, observa-se que o cliente menos preocupado é o atacadista com média de 2,8. É interessante constatar-se que o cliente de maior freqüência, o distribuidor, apresenta nível de preocupação 3,47 (entre alto e altíssimo) na média, indicando a preocupação por parte do consumidor europeu envolvendo esta questão sobre segurança do alimento.

A soma de todos os clientes mencionados pelas 8 empresas é 41 e, realmente, a participação do cliente distribuidor é muito expressiva, ou seja, 41,46\%. Em

${ }^{20}$ Apêndices 8 e 9. 
seguida, aparecem os gerais, processadores e os atacadistas, com 17,07\%, 14,63\% e $12,20 \%$, respectivamente. Os clientes de menor freqüência são representados pela indústria (1), supermercado (5) e restaurante (6) com $2,44 \%$ cada.

\subsubsection{Países dos clientes europeus}

A Tabela 4 refere-se aos países de origem dos respectivos clientes das empresas questionadas com as respectivas freqüências e porcentagens. São 11 países diferentes.

Tabela 4. Países europeus ${ }^{21}$.

\begin{tabular}{lcc}
\hline País & Freqüência & $\%$ \\
\hline Alemanha & 8 & 19,51 \\
Holanda & 7 & 17,07 \\
Reino Unido & 8 & 19,51 \\
Itália & 1 & 2,44 \\
França & 2 & 4,88 \\
Espanha & 1 & 2,44 \\
Portugal & 2 & 4,88 \\
Romênia & 1 & 2,44 \\
Bulgária & 1 & 2,44 \\
Rússia & 1 & 2,44 \\
Suíça & 2 & 4,88 \\
Não Respondeu & 7 & 17,07 \\
Total & 41 & 100 \\
\hline
\end{tabular}

Fonte: Dados da pesquisa.

Ressalta-se que nesa análise de clientes por cada país, está-se considerando todos os tipos de países (países-membros da União Européia, países candidatos à UE, novos países-membros à UE e outros países europeus). Observa-se que os países de maior número de clientes são Alemanha e Reino Unido com 8 cada, o que 
representa 19,51\% para cada país e Holanda com 7 clientes somando 17,07\%. Os países com 1 cliente são Itália, Espanha, Romênia, Bulgária e Rússia, com 4,88\% cada. Pelos dados, observa-se que há uma concentração da exportação de frango para os mercados da Alemanha, Reino Unido e Holanda e uma grande dispersão em relação aos outros oito países.

\subsubsection{Alemanha}

A Tabela 5 trata dos clientes que estão localizados na Alemanha. Dos oito diferentes tipos de clientes, pode-se observar que somente cinco deles estão nesse país.

Tabela 5. Alemanha e seus clientes.

\begin{tabular}{lcc} 
Tipos de clientes & Freqüência & $\%$ \\
\hline Distribuidor & 4 & 44,44 \\
Geral & 2 & 22,22 \\
Atacadista & 1 & 11,11 \\
Processador & 1 & 11,11 \\
Traders & 1 & 11,11 \\
Total & 9 & 100,00
\end{tabular}

Fonte: Dados da pesquisa.

Ao fazer-se uma análise mais detalhada dos países que tiveram a maior concentração de clientes, observa-se que a Alemanha possui os clientes distribuidor com $44,44 \%$, geral com $22,22 \%$ e atacadista, processador e traders, com $11,11 \%$ cada.

\subsubsection{Holanda}

A Tabela 6 contém os dados referentes aos clientes que estão localizados na Holanda. 
Tabela 6. Holanda e seus clientes.

\begin{tabular}{lcc}
\hline Tipos de clientes & Freqüência & $\%$ \\
\hline Distribuidor & 3 & 42,86 \\
Atacadista & 2 & 28,57 \\
Traders & 1 & 14,29 \\
Geral & 1 & 14,29 \\
Total & 7 & 100,00 \\
\hline
\end{tabular}

Fonte: Dados da pesquisa.

A Holanda possui 4 tipos de clientes: distribuidor, atacadista, traders e geral, sendo o distribuidor também o de maior frequiência, correspondendo a 42,86\%.

\subsubsection{Reino Unido}

Nessa questão são analisados os clientes europeus que estão localizados no Reino Unido.

Tabela 7. Reino Unido e seus clientes.

\begin{tabular}{lcc}
\hline Tipos de clientes & Freqüência & $\%$ \\
\hline Distribuidor & 2 & 25,0 \\
Processador & 4 & 50,0 \\
Trader & 1 & 12,5 \\
Geral & 1 & 12,5 \\
Total & 8 & 100,0 \\
\hline
\end{tabular}

Fonte: Dados da pesquisa.

Segundo a Tabela 7, o Reino Unido possui 4 tipos de clientes: processador, distribuidor, trader e geral. Interessante que o processador aparece em $50 \%$ do total de 8 clientes e o distribuidor, que era mais requerente na Alemanha e na Holanda, nesse caso está com $25 \%$ somente. 


\subsubsection{Programas de qualidade}

Com essa questão pretende-se captar quais os programas de qualidade que os clientes passaram a exigir das empresas. Observa-se que a análise dessa tabela será feita por linha, em que cada linha representa um programa de qualidade cuja freqüência representa a soma de todos os clientes das oito empresas questionadas, totalizando-se 41 clientes. Também apresenta-se a porcentagem da freqüência de cada programa de qualidade.

Tabela 8. Programas de qualidade exigidos pelos clientes europeus.

\begin{tabular}{lcc}
\hline Programas de qualidade & Freqüência & $\%$ \\
\hline Nenhum & 1 & 2,43 \\
HACCP & 37 & 90,24 \\
BPF & 36 & 87,80 \\
SSOP & 34 & 82,92 \\
ISO 9000 & 1 & 2,44 \\
Rastreabilidade & 25 & 60,97 \\
Na produção de rações & 20 & 48,78 \\
No abate & 19 & 46,34 \\
No processamento & 17 & 41,46 \\
Não exige rastreabilidade & 7 & 17,07 \\
Outro & 4 & 9,75 \\
\hline
\end{tabular}

Fonte: Dados da pesquisa.

Pela Tabela 8, verifica-se que os programas de qualidade exigidos pelos clientes são Análise de Riscos e Pontos Críticos de Controle (HACCP), Procedimento Padrão de Sanitização e Higiene Operacional (SSOP) e Boas Práticas de Fabricação (BPF) com $90,24 \%, 87,80 \%$ e 82,92\%, respectivamente. A exigência da implantação do sistema de rastreabilidade representou $60,97 \%$ para 41 clientes. Por outro lado, a não exigência desse sistema está representada com 17,07\%. Apesar de o sistema de rastreabilidade ainda não ser uma exigência legislativa, algumas empresas estão se adiantando com a sua implantação. É interessante observar que o programa citado por quatro clientes referem-se à certificação pelo Standard European Food Safety and 
Inspetion Service (EFSIS) e também o British Retailers Consortium (BRC). Por outro lado, os programas de qualidade com freqüência 1 são não exigidos um programa de qualidade e a certificação ISO 9000.

A exigência pelo programa de qualidade ISO 9000 foi dada pela empresa C. No estudo de caso realizado com essa empresa, questionou-se o porquê de ter sido uma resposta única. Perguntou-se: dos programas que os clientes exigiram, o Sr. marcou no questionário que o cliente distribuidor, que é a França, exigiu a ISO 9000. Poderia me explicar isso?

A ISO, conforme os clientes, não é um programa tão importante porque refere-se mais aos processos e procedimentos. Já a certificação pela EFSIS é específica para a higiene alimentar, referente à na qualidade do produto, à sua produção. A decisão de a empresa implantar a ISO deveu-se ao fato de possuir mais uma ferramenta de qualidade - em 2 unidades de exportação e uma unidade de produção de hambúrger iniciado em 1998. É um processo lento de adaptação porque a ISO contribui muito na questão de procedimentos, consciência da empresa em relação à qualidade de produto, aos registros e ao arquivamento. É uma ferramenta a mais que a empresa pensou em adquirir, em 1998, para agregar ao seu programa de qualidade. Ressalta que ela não veio como resposta à exigência. Atualmente os franceses dão mais importância ao programa ISO.

Em 1994 ou 1995, quando surgiu o HACCP, falava-se que a ISO tinha qualidade - a ISO foi um movimento europeu. O HACCP surgiu nos Estados Unidos e a Europa, no princípio, não o considerou importante mas depois de um período de tempo, ela precisou se render ao HACCP. Esse programa é a melhor ferramenta para testar a qualidade do produto - do ponto de vista sanitário - pois é possível obter-se a informatização de todos os controles. Dessa forma, a ISO perdeu um pouco da sua função, no controle de qualidade sanitária do produto mas destaca-se como ferramenta de controle do processo. 
Estão apresentados na Tabela 9 os programas de qualidade distribuídos por cada tipo de cliente.

Tabela 9. Programas de qualidade distribuídos por cada tipo de cliente em porcentagens.

\begin{tabular}{lllllllllllll} 
Tipos de & \multicolumn{10}{c}{ Programas de qualidade } \\
\cline { 2 - 13 } clientes & 0 & 1 & 2 & 3 & 4 & 5 & 6 & 7 & 8 & 9 & 10 \\
\hline Indústria & 0,00 & 100,0 & 100,0 & 100,0 & 0,00 & 100,0 & 100,0 & 100,0 & 100,0 & 0,00 & 0,00 \\
Distribuidor & 0,00 & 88,23 & 64,70 & 94,11 & 5,88 & 52,94 & 41,17 & 23,52 & 17,64 & 17,64 & 5,88 \\
Atacadista & 20,0 & 80,00 & 60,00 & 60,00 & 0,00 & 0,00 & 0,00 & 20,00 & 0,00 & 60,00 & 60,0 \\
Processador & 0,00 & 100,0 & 100,0 & 100,0 & 0,00 & 83,33 & 83,33 & 83,33 & 83,33 & 0,00 & 0,00 \\
Supermerc. & 0,00 & 100,0 & 100,0 & 100,0 & 0,00 & 100,0 & 100,0 & 100,0 & 100,0 & 0,00 & 0,00 \\
Restaurante & 0,00 & 100,0 & 100,0 & 100,0 & 0,00 & 100,0 & 100,0 & 100,0 & 100,0 & 0,00 & 0,00 \\
Traders & 0,00 & 100,0 & 100,0 & 100,0 & 0,00 & 100,0 & 0,00 & 0,00 & 0,00 & 0,00 & 0,00 \\
Geral & 0,00 & 85,71 & 100,0 & 85,71 & 0,00 & 71,42 & 71,42 & 85,71 & 85,71 & 14,28 & 0,00 \\
\hline
\end{tabular}

Fonte: Dados da pesquisa.

Legenda: Programas: 0=nenhum; $1=$ Análise de Riscos e Pontos Críticos de Controle (HACCP); 2=Boas Práticas de Fabricação (BPF); 3=Procedimento Padrão de Sanitização e Higiene Operacional (SSOP); 4=ISO 9000; $5=$ =rastreabilidade em todas as fases de criação animal; $6=$ na produção de rações; $7=$ no abate; $8=$ no processamento; $9=$ não exige rastreabilidade e $10=$ outro.

Conforme a Tabela 9, verifica-se que $100 \%$ dos clientes indústria, processador, supermercado, restaurante e trader exigem os programas Análise de Riscos e Pontos Críticos de Controle (HACCP), Boas Práticas de Fabricação (BPF), Procedimento Padrão de Sanitização e Higiene Operacional (SSOP).

Os programas ISO 9000 e rastreabilidade, em todas as fases de criação animal, na produção de rações, no abate, no processamento são exigidos em $100 \%$ dos clientes indústria, supermercado, restaurante e trader. Esses programas citados são exigidos em $83,33 \%$ dos clientes processadores. 
O cliente distribuidor destaca-se com a exigência dos programas Análise de Riscos e Pontos Críticos de Controle (HACCP), Procedimento Padrão de Sanitização e Higiene Operacional (SSOP) com $\mathbf{8 8 , 2 3 \%}$ e $94,11 \%$ respectivamente.

Verifica-se que $60,0 \%$ dos clientes atacadistas, $17,64 \%$ dos distribuidores e $14,28 \%$ dos gerais não exigem a implantação do sistema de rastreabilidade. É importante ressaltar que o sistema de rastreabilidade ainda não é uma exigência oficial da União Européia. No entanto, as empresas estão se adiantando quanto à sua implantação.

\subsubsection{Exigências dos clientes europeus em relação à matéria-prima}

Na Tabela 10, faz-se uma análise das exigências dos clientes europeus junto às empresas avícolas exportadoras de frango, com a respectiva freqüência $\mathrm{e}$ porcentagem. Essa porcentagem foi calculada considerando-se o total de 41 clientes para cada exigência.

Tabela 10. Exigências dos clientes europeus com relação à matéria-prima.

\begin{tabular}{lcc}
\hline Exigências em relação à matéria-prima & Freqüência & $\%$ \\
\hline Não usar grãos geneticamente modificados & 18 & 43,90 \\
Não usar ingredientes de origem animal & 24 & 58,53 \\
Não usar promotores de crescimento & 22 & 53,65 \\
Não usar aditivos alimentares & 20 & 48,78 \\
Não usar antibióticos & 16 & 39,02 \\
Outra & 10 & 24,39 \\
\hline
\end{tabular}

Fonte: Dados da pesquisa.

Considerando-se que na Tabela 10 constam os dados agrupados dos 41 clientes, destacam-se os itens não usar ingredientes de origem animal e promotores de crescimento, com freqüência de 24 e 22 o que representa $58,53 \%$ e $53,65 \%$ respectivamente. Observa-se que as outras exigências listadas: não usar aditivos, grãos geneticamente modificados e antibióticos também se aproximam das citadas 
anteriormente com $48,78 \%, 43,90 \%$ e $39,02 \%$ respectivamente. Outras exigências que os clientes fazem estão citadas na opção "outra", com 24,39\%, que são: não usar determinados compostos como nitrofurano, clorofenicol e outros do plano nacional de controle de resíduos biológicos. Acrescenta-se também que os clientes da empresa B exigem que somente sejam utilizados promotores de crescimento, antibióticos e aditivos permitidos pela UE.

A Tabela 11 apresenta os resultados referentes às exigências em relação à matéria-prima por tipo de cliente, em porcentagens. Para esses cálculos, considerou-se o número total por cada tipo de cliente.

Tabela 11. Exigências de cada cliente com relação à matéria-prima utilizada na produção de carne de frango ${ }^{22}$.

Exigências em relação à matéria-prima

\begin{tabular}{lcccccc} 
Tipos de clientes & 1 & 2 & 3 & 4 & 5 & 6 \\
\hline Indústria & 100,0 & 100,0 & 100,0 & 100,0 & 100,0 & 0,00 \\
Distribuidor & 29,41 & 35,29 & 29,41 & 41,17 & 35,29 & 29,41 \\
Atacadista & 40,00 & 80,00 & 60,00 & 60,00 & 40,00 & 20,00 \\
Processador & 83,33 & 100,0 & 83,33 & 66,66 & 66,66 & 0,00 \\
Supermercado & 0,00 & 100,0 & 100,0 & 100,0 & 100,0 & 0,00 \\
Restaurante & 100,0 & 100,0 & 100,0 & 100,0 & 100,0 & 0,00 \\
Traders & 0,00 & 0,00 & 100,0 & 66,66 & 0,00 & 66,66 \\
Geral & 57,14 & 71,43 & 42,85 & 14,28 & 14,28 & 0,00 \\
\hline
\end{tabular}

Fonte: Dados da pesquisa.

Legenda: 1=não usar grãos geneticamente modificados; $2=$ não usar ingredientes de origem animal; $3=$ não usar promotores de crescimento; 4=não usar aditivos alimentares; $5=$ não usar antibióticos e $6=$ outra.

Observa-se que $100 \%$ das exigências dos clientes indústria e supermercado referem-se à não utilização de grãos geneticamente modificados,

\footnotetext{
${ }^{22}$ Apêndice 11.
} 
ingredientes de origem animal, promotores de crescimento, aditivos alimentares e antibióticos.

Tanto o cliente trader como o supermercado não exigem que os grãos utilizados para a composição da ração não sejam transgênicos. Observa-se que a legislação na União Européia não permite que grãos geneticamente modificados sejam utilizados na composição da ração, salvo em casos em que a porcentagem não ultrapasse $1 \%$.

Os dados mostram que o cliente distribuidor, que nas análises anteriores destacava-se, não ocorre nesse item. Para os distribuidores (que totalizam 17), a freqüência de cada exigência foi baixa, o que significa que existem outras exigências importantes que não foram mencionadas nessa pergunta.

\subsubsection{Opinião da empresa}

As questões da Tabela 12 foram respondidas com a opção sim ou não pelas oito empresas.

Tabela 12. Opiniões das empresas em relação às exigências dos clientes europeus.

\begin{tabular}{|c|c|c|c|}
\hline \multirow[b]{2}{*}{ Empresas } & \multicolumn{2}{|c|}{ Opinião das empresas } & \multirow[b]{2}{*}{3} \\
\hline & 1 & 2 & \\
\hline $\mathrm{A}$ & Sim & Não & Sim \\
\hline $\mathrm{B}$ & $\mathrm{Sim}$ & Não & Sim \\
\hline $\mathrm{C}$ & Sim & Sim & Sim \\
\hline $\mathrm{D}$ & Sim & Não & Sim \\
\hline $\mathrm{E}$ & $\operatorname{sim}$ & Sim & Sim \\
\hline
\end{tabular}


Tabela 12. Opiniões das empresas em relação às exigências dos clientes europeus.

\begin{tabular}{cccc} 
& \multicolumn{3}{c}{ Opinião das empresas } \\
\cline { 2 - 4 } Empresas & 1 & 2 & 3 \\
\hline F & não & Sim & Sim \\
G & Sim & Sim & Sim \\
H & Sim & Sim & Sim \\
\hline
\end{tabular}

Fonte: Dados da pesquisa.

Legenda: $1=$ essas exigências retratam a opinião e as preocupações dos consumidores; $2=$ estas exigências representam barreiras não-tarifárias e $3=$ essas exigências precisam ser cumpridas para que a empresa permaneça no mercado europeu.

$\mathrm{Na}$ primeira questão, $87,50 \%$ das empresas responderam que estas exigências retratam a opinião e preocupações dos consumidores. Na segunda questão, também teve resposta sim, com $62,50 \%$, opinando que estas exigências representam barreiras não-tarifárias. Finalmente a terceira questão, com 100\% de resposta sim, refere-se ao cumprimento das exigências para permanecer no mercado europeu.

\subsubsection{Medidas adotadas}

A Tabela 13 relaciona as medidas que as empresas avícolas exportadoras tomaram para atender ao cliente europeu, com a respectiva freqüência e porcentagem. Para o cálculo dessa porcentagem considerou-se o número total de clientes, ou seja, 41.

Tabela 13. Medidas adotadas pelas empresas.

\begin{tabular}{lccc}
\hline \multicolumn{1}{c}{ Medidas adotadas } & Freqüência & $\%$ \\
\hline assegurar-se das fontes de fornecimentos de m.p. & 35 & $\mathbf{8 5 , 3 6}$ \\
investir em pesquisa e tecnologia & 20 & 48,78 \\
contratar mão-de-obra especializada & 19 & 46,34 \\
passou a implantar sistema de rastreabilidade & 31 & 75,61 \\
passou a implantar programas de qualidade & 35 & 85,36 \\
Não adotou nenhuma medida & 0 & 0,00 \\
Outro & 0 & 0,00 \\
\hline
\end{tabular}

Fonte: Dados da pesquisa. 
Conforme a Tabela 14, as principais medidas adotadas pelas empresas para atender aos seus clientes referem-se, com $85,36 \%$, ao asseguramento das fontes de matérias-primas e também à implantação de programas de qualidade. A implantação do sistema de rastreabilidade na empresa também teve destaque no atendimento de $75,61 \%$ dos clientes. Os investimentos em pesquisa e tecnologia e a contratação de mão-de-obra especializada tiveram as freqüências mais baixas (20 e 19), mas foram expressivas, com $48,78 \%$ e $46,34 \%$, respectivamente. Por fim, pode-se ver que as opções "nenhuma medida foi adotada" ou, "alguma outra para satisfazer os clientes", não tiveram freqüência. Significa dizer que todas as empresas que responderam ao questionário tomaram alguma medida com relação ao atendimento das exigências de seus clientes.

$\mathrm{Na}$ Tabela 14 constam os resultados referentes às medidas adotadas pelas empresas avícolas no atendimentos de seus respectivos clientes europeus.

Tabela 14. Medidas adotadas pelas empresas por tipo de cliente.

\begin{tabular}{lccccc}
\hline & \multicolumn{5}{c}{ Medidas adotadas } \\
\cline { 2 - 6 } Tipos de clientes & 1 & 2 & 3 & 4 & 5 \\
\hline Indústria & 100,0 & 100,0 & 100,0 & 100,0 & 100,0 \\
Distribuidor & 64,70 & 47,05 & 23,52 & 52,94 & 70,58 \\
Atacadista & 100,0 & 80,00 & 40,00 & 60,00 & 100,0 \\
Processador & 100,0 & 83,33 & 66,66 & 100,0 & 100,0 \\
Supermercado & 100,0 & 100,0 & 100,0 & 100,0 & 100,0 \\
Restaurante & 100,0 & 100,0 & 100,0 & 100,0 & 100,0 \\
Traders & 100,0 & 0,00 & 0,00 & 100,0 & 100,0 \\
Geral & 100,0 & 0,00 & 85,71 & 85,71 & 85,71 \\
\hline
\end{tabular}

Fonte: Dados da pesquisa.

Legenda: $1=$ assegurar-se das fontes de fornecimentos de matérias-primas; $2=$ investir em pesquisa e tecnologia; $3=$ contratar mão-de-obra especializada; $4=$ passou a implantar sistema de rastreabilidade e $5=$ passou a implantar programas de qualidade. 
Observa-se que $100 \%$ dos clientes indústria, supermercado e restaurante tiveram as medidas adotadas pelas empresas, que são: asseguraram-se das fontes de fornecimento de matéria-prima; investimento em pesquisa e tecnologia; contratação de mão-de-obra especializada; a implantação do sistema de rastreabilidade e de programas de qualidade.

Em relação ao cliente processador, $100 \%$ tiveram as medidas adotadas pelas empresas no que se refere ao asseguramento das fontes de fornecimento de matéria-prima, implantação sistema de rastreabilidade e de programas de qualidade. Os investimentos em pesquisa e tecnologia e a contratação de mão-de-obra especializada foram adotados com $83,33 \%$ e $66,66 \%$, respectivamente.

O cliente distribuidor apresenta bastante oscilação em seus resultados. Citam-se como as mais expressivas o asseguramento das fontes de matérias-primas e a implantação de programas de qualidade com $70,58 \%$ e $64,70 \%$ respectivamente, como as medidas adotadas pelas empresas avícolas para $o$ atendimento de exigências de seus clientes.

\subsubsection{Demandas feitas ao setor público}

Esta questão avalia as demandas em relação à atuação do setor público na solução das exigências dos clientes europeus.

Tabela 15. Opinião das empresas em relação à atuação do setor público.

\begin{tabular}{cccccc}
\hline & \multicolumn{5}{c}{ Opinião das empresas } \\
\cline { 2 - 6 } Empresas & 1 & 2 & 3 & 4 & 5 \\
\hline A & $\cdot$ & & X & X & $\cdot$ \\
B &. & X & X & X & $\cdot$ \\
C &. & & X & X & $\cdot$ \\
D &. & X & X & $\cdot$ & $\cdot$ \\
E &. & X & X & X & $\cdot$ \\
F &. &. & X & $\cdot$ & $\cdot$ \\
G &. &. & $X$ &. & X
\end{tabular}


Tabela 15. Opinião das empresas em relação à atuação do setor público.

\begin{tabular}{cccccc}
\hline & \multicolumn{5}{c}{ Opinião das empresas } \\
\cline { 2 - 6 } Empresas & 1 & 2 & 3 & 4 & 5 \\
\hline $\mathrm{G}$ & $\cdot$ & $\cdot$ & $\mathrm{X}$ & $\cdot$ & $\mathrm{X}$ \\
$\mathrm{H}$ & $\cdot$ & $\mathrm{X}$ & $\mathrm{X}$ & $\cdot$ & $\mathrm{X}$ \\
Total & 0 & 4 & 8 & 4 & 2 \\
\hline
\end{tabular}

Fonte: Dados da pesquisa.

Legenda: 1=nada a declarar; $2=$ emissão de selos de qualidade; $3=$ laboratórios de análise de resíduos; $4=$ pesquisas para confrontar com os resultados europeus e $5=$ outro.

Observa-se que $100 \%$ das empresas responderam que o setor público deveria atuar na solução das exigências dos clientes europeus com a implantação de laboratórios de análise de resíduos. As opções emitir selos de qualidade e pesquisas para confrontar com resultados europeus ficaram com $50 \%$ cada. A outra opção, refere-se particularmente ao fato de a Europa preferir que os controles fiquem a cargo dos órgãos oficiais e que deveria ocorrer uma relação mais estreita das empresas avícolas com o MAPA para discussão de questões de interesse do Brasil.

\subsection{Fornecedores de matéria-prima}

Essa questão está subdividida em três itens.

\subsubsection{Matéria-prima frango}

A Tabela 16 mostra as respostas das empresas em relação à compra da matéria-prima frango, antes de 1996, e como essa compra é realizada atualmente.

Tabela 16. Matéria-prima frango.

\begin{tabular}{cccc}
\hline Freqüência de empresas & Antes de 1996 & Atualmente & $\%$ \\
\hline 8 & via contrato integrado & via contrato integrado & 100,00 \\
\hline
\end{tabular}

Fonte: Dados da pesquisa.

Observa-se, na Tabela 16, que $100 \%$ das empresas adquiriam a matériaprima frango, antes de 1996, via contrato integrado e pode-se ver que, atualmente, $100 \%$ das empresas continuam comprando da mesma forma. Verifica-se, dessa forma, a 
presença da forma híbrida como estrutura de governança prevalecente na compra da matéria-prima frango, por parte da indústria avícola brasileira.

\subsubsection{Relacionamento com seu fornecedor de grãos}

A Tabela 17 mostra as respostas das empresas sobre seu relacionamento com seus fornecedores de grãos, antes de 1996 e atualmente.

Tabela 17. Relacionamento entre as empresas e seus fornecedores de grãos.

\begin{tabular}{cllc}
\hline Freqüência de empresas & \multicolumn{1}{c}{ Antes de 1996 } & Atualmente & $\%$ \\
\hline 3 & via compra no mercado & nada mudou & 37,5 \\
2 & via contrato integrado & nada mudou & 25 \\
1 & via mercado e fornecedor cadastrado & nada mudou & 12,5 \\
1 & via contrato cooperativas & nada mudou & 12,5 \\
1 & via contrato integrado & cooperados & 12,5 \\
Total (8) & & & 100,00 \\
\hline
\end{tabular}

Fonte: Dados da pesquisa.

O relacionamento das 8 empresas com seus respectivos fornecedores de grãos é distinto para cada uma delas. Observa-se que $37,5 \%$ das empresas compravam grãos via mercado e que, após a intensificação da legislação européia com relação à proibição do uso de grãos geneticamente modificados, afirmam que nada mudou, indicando que está havendo um equívoco de conceitos. Conforme a Teoria da Economia dos Custos de Transação, a estrutura de governança, com a opção de "compra no mercado" explica que a sinalização de preços é suficiente para controlar o mercado. No entanto, adquiridos de seus fornecedores as empresas impõem que os grãos sejam não transgênicos. Mais precisamente, trata-se de um ativo altamente específico.

Verifica-se, portanto, que o conceito sobre a opção "compra no mercado", segundo a Teoria da ECT, difere daquele dotado pelas empresas. Acredita-se que a pessoa que respondeu ao questionário desconheça a teoria e considere o método utilizado pela empresa como a compra no mercado, quando na verdade, trata-se de um relacionamento contratual. 
Nos estudos de caso, pode-se aprofundar essa questão, verificando-se que existem cláusulas contratuais entre as empresas e os fornecedores de grãos. São realizados testes se a carga não estiver em conformidade com as especificidades contidas no contrato, a mesma é devolvida.

Conforme os resultados obtidos com os questionários, duas empresas compravam grãos via contrato integrado, uma, via mercado e fornecedor cadastrado e uma, com contrato com cooperativas e atualmente, continua da mesma forma. Somente uma empresa passou a comprar grãos de contrato integrado para cooperados. Percebe-se, nos estudos de caso, que aquela que comprava no mercado e com fornecedor cadastrado realiza também testes para se assegurar da origem dos grãos. Essa compra no mercado é realizada junto a uma grande empresa de grãos.

Portanto, apesar de nos resultados dos questionários não se constatarem mudanças na estrutura de governança, salvo com uma exceção, afirma-se que ocorreram mudanças contratuais, prevalecendo a estrutura híbrida.

\subsubsection{Relacionamento com o fornecedor de premix}

A Tabela 18 refere-se ao relacionamento entre a empresa e seu fornecedor de premix antes de 1996 e atualmente.

Tabela 18. Relacionamento das empresas com seus fornecedores de premix.

\begin{tabular}{cllc}
\hline Frequêencia de empresas & \multicolumn{1}{c}{ Antes de 1996 } & Atualmente & $\%$ \\
\hline 4 & via contrato & nada mudou & 50,0 \\
1 & via mercado & nada mudou & 12,5 \\
1 & via mercado e contrato & nada mudou & 12,5 \\
1 & via mercado & via contrato & 12,5 \\
1 & não respondeu & - & 12,5 \\
Total (8) & & & 100,00 \\
\hline
\end{tabular}

Fonte: Dados da pesquisa. 
Observa-se dentre as empresas que responderam nenhuma produz o seu próprio premix. O premix é comprado de uma empresa que o prepara conforme as exigências de cada cliente.

Pelas respostas dos questionários, percebe-se que $50 \%$ das empresas compravam o premix com contrato e atualmente continua assim. Os outros casos, como a compra no mercado e o fato de não terem havido mudanças mostra que o fato de a própria empresa não produzir seu premix significa dizer, de acordo com a pessoa que respondeu, que a compra é feita via mercado. Entretanto, percebe-se novamente que há uma discrepância entre o que a pessoa entende por compra via mercado e a Teoria da ECT.

Posteriormente, nos estudos de caso, verifica-se que a fórmula do premix é passada para a fornecedora do mesmo e ela o produzirá conforme as especificidades do contrato. Salienta-se que cada cliente exige que a empresa avícola produza o frango conforme suas exigências e dentro destas, encontra-se o premix. Ou seja, os fornecedores precisam atingir o padrão requisitado pela empresa avícola.

Portanto, contrastando-se os resultados dos questionários, destaca-se que a estrutura de governança prevalecente no relacionamento entre a empresa avícola e a fornecedora de premix caracteriza-se como a híbrida.

\subsection{Estudos de caso}

Neste tópico, apresentam-se os resultados dos estudos de caso das empresas A, C e H. Em cada quadro estão as respostas referentes a cada pergunta. As entrevistas dos três estudos de caso foram gravadas e transcritas. 
No Quadro 2 constam as respostas das empresas $\mathrm{A}, \mathrm{C}$ e $\mathrm{H}$ no que se refere ao tempo que as mesmas exportam para a União Européia.

\begin{tabular}{|c|l|}
\hline Empresa & \multicolumn{1}{|c|}{ Respostas } \\
\hline Empresa A & A empresa exporta para a UE há 3 anos. \\
\hline Empresa C & Começou a exportar para a UE há uns 15 ou 16 anos. \\
\hline Empresa H & A empresa exporta para a UE há mais de 10 anos. \\
\hline
\end{tabular}

Quadro 2 - Desde quando a empresa exporta para a União Européia?

Fonte: Dados da pesquisa.

O Quadro 3 estão as respostas que as empresas deram em relação em relação à importância da UE para cada uma.

\begin{tabular}{|c|l|}
\hline Empresa & \multicolumn{1}{|c|}{ Respostas } \\
\hline Empresa A & $\begin{array}{l}\text { A União Européia representa o segundo lugar das exportações da empresa, em } \\
\text { termos de volume. Em primeiro lugar está o Japão. }\end{array}$ \\
\hline Empresa C & $\begin{array}{l}\text { Também em termos de volume a União Européia é o segundo. O primeiro em } \\
\text { volume é o Oriente Médio, que compra frango inteiro, por isso, a quantidade é } \\
\text { mais expressiva. Em termos de rentabilidade, a primeira é a Europa. }\end{array}$ \\
\hline Empresa H & Na ordem de volume a UE também é o segundo maior cliente. \\
\hline
\end{tabular}

Quadro 3 - Qual a ordem de importância da UE na lista dos clientes?

Fonte: Dados da pesquisa.

O próximo Quadro apresenta as respostas do porquê de a empresa exportar para a União Européia.

\begin{tabular}{|c|l|}
\hline Empresa & \multicolumn{1}{|c|}{ Respostas } \\
\hline Empresa A & $\begin{array}{l}\text { A empresa optou por exportar para a UE tentando a estratégia de pulverizar } \\
\text { mercados, para não depender de um só. A Europa é responsável pela importação } \\
\text { de peito e o Japão pela coxa e sobre-coxa. }\end{array}$ \\
\hline Empresa C & $\begin{array}{l}\text { Dentro da Europa, a Inglaterra é o mercado mais promissor e rentável. A empresa } \\
\text { exporta produtos para a Holanda e Alemanha onde os mesmos são } \\
\text { remanufaturados e posteriormente, vendidos para a Inglaterra. Para a empresa, } \\
\text { isso é uma ótima vitrine porque está exportando para o mercado mais exigente, } \\
\text { que é a Europa. Conseguindo atingir um mercado como esse indica que a } \\
\text { empresa tem qualidade, além de contribuir para o fortalecimento da sua marca.. }\end{array}$
\end{tabular}


| Empresa H $\mid$ A empresa considera que não é uma questão de opção. O que está acontecendo é um mix normal em que cada mercado compra um produto específico. Por exemplo, o frango inteiro é comprado pelo Oriente Médio, o peito pela Europa, as coxas desossadas pelo Japão e o restante, como asas, pela China e outros mercados.

Quadro 4 - Por que a empresa optou para exportar por este mercado?

Fonte: Dados da pesquisa.

O Quadro 5 mostra a produção exportada em dólares para a União

Européia.

\begin{tabular}{|c|l|}
\hline Empresa & \multicolumn{1}{|c|}{ Respostas } \\
\hline Empresa A & Em 2002, US\$ 8.124.932,91 \\
\hline Empresa C & Em 2002, 718 milhões de reais \\
\hline Empresa H & Estes dados a empresa não revela. \\
\hline
\end{tabular}

Quadro 5 - A produção exportada para a UE no período de 1996-2002 em US\$.

Fonte: Dados da pesquisa.

No Quadro 6 estão explicadas as funções e as características de cada cliente europeu com o qual as empresas comercializam.

\begin{tabular}{|c|l|}
\hline Empresa & \multicolumn{1}{|c|}{ Respostas } \\
\hline Empresa A & $\begin{array}{l}\text { Considera indústria empresas que processam o produto no mercado europeu - é } \\
\text { exportado in natura para a Europa. Os distribuidores seriam grandes } \\
\text { importadores europeus que fazem a distribuição dos produtos para supermercados } \\
\text { e restaurantes. Em seguida, viriam os restaurantes e supermercados } \\
\text { considerados, pela empresa, clientes indiretos. A empresa faz o produto } \\
\text { conforme estes 2 clientes especificam, mas não o exporta diretamente para os } \\
\text { mesmos. Quem faz a entrega deste produto é o distribuidor. }\end{array}$ \\
\hline Empresa C & $\begin{array}{l}\text { Os distribuidores compram o produto in natura e muitas vezes o descongelam, } \\
\text { reempacotando em embalagens de 1 ou 2 kg, com dois ou três filés - de acordo } \\
\text { com que o cliente final quer - e põe no supermercado sem a marca da empresa. } \\
\text { Muitas vezes estes produtos levam a marca do supermercado ou nenhuma. Os } \\
\text { processadores compram e processam produtos. O próximo passo para a empresa é } \\
\text { passar para estes produtos elaborados. }\end{array}$ \\
\hline
\end{tabular}


\begin{tabular}{|l|l|} 
Empresa $\mathbf{H}$ & $\begin{array}{l}\text { A empresa classificou seus clientes como geral por considerar que a empresa tem } \\
\text { vários tipos de clientes. A maioria desses clientes são industrializadores que } \\
\text { compram para revender para a indústria - os produtos nos supermercados são na } \\
\text { maioria frescos. Além de exportar frango in natura, ela também exporta produtos } \\
\text { temperados e cozidos que são processados, resultando em embutidos, nuggets, } \\
\text { entre outros, e vendidos aos supermercados sem a marca da empresa. }\end{array}$
\end{tabular}

Quadro 6 - Explique a função do cliente europeu com o qual sua empresa trabalha (processador, distribuidor, trader).

Fonte: Dados da pesquisa.

As respostas para a pergunta: desde quando o cliente passou a exigir que a empresa implantasse programas de qualidade, estão no Quadro 7.

\begin{tabular}{|c|l|}
\hline Empresa & \multicolumn{1}{|c|}{ Respostas } \\
\hline Empresa A & $\begin{array}{l}\text { A empresa não teve nenhuma exigência por parte dos clientes em relação a } \\
\text { implantação de programas de qualidade. A qualidade dos produtos foi sempre sua } \\
\text { prioridade, fator que proporcionou o crescimento acelerado da produção. Ressalta } \\
\text { que possui o processo de desossa manual e não mecanizado o que agrega muito } \\
\text { valor aos cortes, cumprindo as especificações exigidas elos clientes. }\end{array}$ \\
\hline Empresa C & $\begin{array}{l}\text { Os problemas causados pelo mal da vaca louca e as exigências com programas de } \\
\text { qualidade são independentes. Em 1998 a empresa já tinha a certificação pelo } \\
\text { EFSIS, exigida pelo mercado inglês. Eleita pelos supermercados ingleses como } \\
\text { sendo a empresa que pode auditar os fornecedores diretos e os fornecedores dos } \\
\text { fornecedores dos produtores de matéria-prima, adquiriu os padrões do BRC } \\
\text { (British Retailers Consortium) - no Brasil corresponde ao ABRAS (Associação } \\
\text { Brasileira de Supermercados), onde estão os 17 maiores supermercados. }\end{array}$ \\
\hline Empresa H & $\begin{array}{l}\text { O problema da vaca louca também contribuiu. Isso depende de cliente para } \\
\text { cliente, mas as exigências de programas de qualidade vêm sendo mais } \\
\text { expressivas há uns 5 ou 6 anos. }\end{array}$ \\
\hline
\end{tabular}

Quadro 7 - Desde quando o cliente passou a exigir que a empresa implantasse programas de qualidade?

Fonte: Dados da pesquisa.

O Quadro 8 trata a questão da certificação do Serviço Europeu de Segurança do Alimento (EFSIS). 


\begin{tabular}{|c|l|}
\hline Empresa & \multicolumn{1}{|c|}{ Respostas } \\
\hline Empresa A & $\begin{array}{l}\text { O EFSIS é a empresa que dá a certificação. Dos programas que a empresas } \\
\text { possui, dentro do EFSIS está o HACCP, que já está sendo implantado - desde o } \\
\text { refeitório até a parte externa (das galinhas poedeiras até o processo final) - e irá } \\
\text { solicitar para alguma certificadora emitir o certificado. }\end{array}$ \\
\hline Empresa C & $\begin{array}{l}\text { A empresa tem o certificado EFSIS desde 1998. A EFSIS é como a ISO que é } \\
\text { por unidade de produção. Atualmente a empresa tem EFSIS em duas unidades de } \\
\text { produção que estrategicamente mais exportam: cubos, tiras, peitos inteiros } \\
\text { cozidos e a outra que produz todos os tipos de empanados para o mercado interno } \\
\text { e exportação. Numa outra unidade, 100\% da produção destina-se para o Oriente } \\
\text { Médio. Dessa forma, a empresa regionaliza, em cada região a produção para um } \\
\text { mercado específico. }\end{array}$ \\
\hline Empresa H & \begin{tabular}{l} 
Pela sigla não sei a que se refere. \\
\hline
\end{tabular}
\end{tabular}

Quadro 8 - Desde quando implantou o Programa EFSIS? Se não implantou, ainda não foi exigido pelos clientes?

Fonte: Dados da pesquisa.

O Quadro 9 se refere ao sistema de rastreabilidade implantado em cada empresa.

\begin{tabular}{|c|l|}
\hline Empresa & \multicolumn{1}{|c|}{ Respostas } \\
\hline Empresa A & $\begin{array}{l}\text { O processo de rastreabilidade é feito por lote de frangos. Nesse processo, é } \\
\text { possível rastrear desde a ração, a medicação que teve o lote, quem foram as } \\
\text { matrizes desses frangos, quais foram os alimentos que essas matrizes consumiram } \\
\text { ou seja, há o controle desde a matriz até o produto final. Cada aviário possui um } \\
\text { número de lote e cada lote varia de } 7.500 \text { a } 14.000 \text { mil frangos. Quando o } \\
\text { caminhão chega na empresa, sabe-se ao certo a procedência do lote onde o } \\
\text { mesmo aguarda por até no máximo duas horas num box de repouso, para que os } \\
\text { frangos possam descansar e relaxar, objetivando-se o bem-estar animal - exigido } \\
\text { pela UE. Um responsável no frigorífico informa no sistema qual é o lote que está } \\
\text { chegando; quando o frango começa a ser pendurado, ele coloca uma placa com o } \\
\text { número do lote que acompanha todo o processo produtivo - desde a hora da } \\
\text { pendura, no processo final, até a enumeração das embalagens dos produtos, e } \\
\text { finalmente em rótulos nas caixas. O sistema implantado na empresa é } \\
\text { considerado ótimo pois consegue armazenar todos os dados. A UE está muito } \\
\text { exigente quanto à presença de nitrofurano e se tiver algum problema, é possivel } \\
\text { saber a origem do mesmo. Por enquanto, a empresa não teve nenhum problema } \\
\text { desse gênero. }\end{array}$ \\
\hline Empresa C Co & $\begin{array}{l}\text { Na FAL - Ficha de Acompanhamento de Lote - constam dados como: quem é o } \\
\text { produtor, o produto que ele está produzindo, ração o frango dele comeu, quantos } \\
\text { pintinhos morreram, o porquê da morte, medicamentos, os tipos e lote de vacinas. } \\
\text { O escritório central tem a informação sobre a ração, sobre o integrado e sobre o }\end{array}$ \\
\hline
\end{tabular}




\begin{tabular}{|l|l|} 
incubatório. A FAL acompanha o lote para o abatedouro. Por causa do último \\
escândalo sobre o nitrofurano, a empresa melhorou esse sistema de \\
rastreabilidade dividindo o abate em turnos e períodos. O sistema implantado na \\
empresa é considerado até melhor que o da Europa (conseguem trabalhar por \\
turno). A dificuldade de se trabalhar em períodos requer que seja necessário \\
trabalhar com intervalos de produção por causa do volume de produção. O frango \\
sai da granja, ele espera no máximo uma hora no caminhão para ser abatido, o \\
que evita que o mesmo fique estressado e aumente dessa forma, o índice de \\
mortalidade. Cada periodo abate os frangos de 2 a 4 integrados, o que \\
corresponde a 50.000 frangos aproximadamente - cada integrado são 15.000 \\
frangos. Resumindo, a rastreabilidade na empresa funciona com data e período de \\
produção - tudo isso relacionado com a FAL - e depois, na produção tem-se todos \\
os dados, tanto o que o HACCP da empresa está determinando como algumas \\
especificações que são para clientes.
\end{tabular}

Quadro 9 - Como é o sistema de rastreabilidade implantado? (por lote, por origem, por data de abate, por tipo de destino de cliente, etc.).

Fonte: Dados da pesquisa.

No Quadro 10 constam outras exigências dos clientes europeus, além das já citadas como não usar grãos geneticamente modificados, não usar subprodutos de origem animal, aditivos, antibióticos e promotores de crescimento.

\begin{tabular}{|c|l|}
\hline Empresa & \multicolumn{1}{|c|}{ Respostas } \\
\hline Empresa A & $\begin{array}{l}\text { Alguns clientes passaram a exigir frangos alimentados só com vegetais como } \\
\text { milho e soja, sem GMO e sem antibióticos. O que acontece muitas vezes é que o } \\
\text { resultado do próprio lote diminui por não ser possível dar um tratamento } \\
\text { adequado ao mesmo devido à exigência do cliente. }\end{array}$ \\
\hline Empresa C & $\begin{array}{l}\text { A questão do bem-estar animal é exigida principalmente pela Inglaterra. Todas as } \\
\text { restrições relacionadas a antibióticos e promotores de crescimento são sempre } \\
\text { cobradas. Os técnicos querem olhar as granjas, antes de o frango estar pronto, o } \\
\text { incubatório e a fábrica de rações, permanecendo um dia em cada sub-unidade. } \\
\text { Então, bem-estar não é só para o frango da granja, mas sim tudo o que vem antes: } \\
\text { como era o bem-estar da avó dele, bem-estar do pintinho no incubatório, se ele } \\
\text { pode expressar os movimentos, ser livre de dor, livre de qualquer coisa que cause } \\
\text { injúria, livre de fome e sede. Quando os europeus comerem o frango querem }\end{array}$
\end{tabular}




\begin{tabular}{|c|c|} 
& $\begin{array}{l}\text { imaginar que esse frango foi-tratado. Em cada unidade de produção tem uma } \\
\text { pessoa responsável pelo bem-estar do animal no setor de desembarque. O } \\
\text { brasileiro, como consumidor, não está muito preocupado com essas questões, mas } \\
\text { ele acaba tendo sorte porque nas mesmas unidades onde são feitos produtos para } \\
\text { exportar são feitos aqueles destinados ao mercado interno. }\end{array}$ \\
\hline Empresa H & Bem-estar animal, rastreabilidade e HACCP. \\
\hline Quadro 10 - Além das exigências (grãos geneticamente modificados; subprodutos de \\
origem animal; aditivos, antibióticos; promotores de crescimento) \\
existem outras que os clientes europeus passarão a exigir em breve?
\end{tabular}

Fonte: Dados da pesquisa.

No Quadro seguinte, estão as respostas relacionadas às medidas que cada empresa adotou para atender seus clientes europeus.

\begin{tabular}{|c|l|}
\hline Empresa & \multicolumn{1}{c|}{ Respostas } \\
\hline Empresa A & $\begin{array}{l}\text { Todas as medidas adotadas pela empresa - não tem os uma linha de produção só } \\
\text { para a Europa ou só para o Japão - são adequados para todos os clientes, seja } \\
\text { mercado interno ou externo. Dessa forma, o processo de rastreabilidade ou o } \\
\text { HACCP favorece a todos os clientes. Por exemplo, não é possível abater no } \\
\text { perído da manhã frango que vão para a Europa e ter controles diferentes. A } \\
\text { adoção de medidas para atender a todos os clientes é uma opção da empresa e } \\
\text { isso fornece um resultado positivo para todos os mercados. }\end{array}$ \\
\hline Empresa C & $\begin{array}{l}\text { Essas medidas são, em primeiro lugar, para atender o cliente europeu e } \\
\text { posteriormente, outros mercados começam a exigir também. A China não se } \\
\text { preocupa com questões ligadas ao bem-estar animal, controle de ração, não usar } \\
\text { antibióticos, além de não ter essa estrutura verticalizada como se tem no Brasil. O } \\
\text { mesmo acontece com a Tailândia que sofreu muito com o nitrofurano, mas, em } \\
\text { compensação, ela é muito bem vista pelos europeus porque ela foi o primeiro } \\
\text { país a colocar produtos processados na Europa. Em contrapartida, o processo } \\
\text { produtivo é manual e por isso que não conseguem fazer volume além de ser um } \\
\text { país pequeno e com uma série de problemas sociais. Portanto, a Europa é o carro } \\
\text { chefe que lidera e o Brasil é o país que sempre o acompanha. }\end{array}$ \\
\hline Empresa H & $\begin{array}{l}\text { O processo na empresa é contínuo. Durante o abate as carcaças são classificadas } \\
\text { (peso, qualidade...) e dirigidas à produção para mercados específicos. Assim, um } \\
\text { mesmo lote de frangos poderá gerar produtos para a Europa, Japão, Arábia e } \\
\text { mercado interno ao mesmo tempo. Sendo assim, as exigências de um mercado } \\
\text { passam a ser adotadas a todos os mercados. }\end{array}$ \\
\hline
\end{tabular}

Quadro 11 - Em relação às medidas que a empresa adotou para atender os clientes, elas foram adotadas somente para atender a solicitação dos clientes europeus ou também para atender outros clientes?

Fonte: Dados da pesquisa. 
O Quadro 12 apresenta as respostas sobre a existência ou não de outras medidas importantes que cada empresa tenha adotado para satisfazer os clientes europeus.

\begin{tabular}{|c|c|}
\hline esa & Respostas \\
\hline Empresa A & $\begin{array}{l}\text { A empresa tem um convênio com uma universidade, que faz diariamente, toda a } \\
\text { análise bacteriológica de produtos ao longo de todo o processo produtivo. Optou } \\
\text { por fazer dessa forma por dois motivos, primeiro, por não precisar montar um } \\
\text { laboratório dentro da empresa - com a possibilidade de manipular os dados -, e } \\
\text { segundo, para aumentar sua credibilidade frente aos clientes. Forneceu à } \\
\text { universidade toda a estrutura para realizar essas análises com a colaboração de } \\
\text { seus alunos e professores. Ressalta que a adoção desse procedimento não é } \\
\text { requisito de clientes, mas sim, uma opção que a empresa fez por estar preocupada } \\
\text { com a segurança do alimento e que este não venha a causar nenhum problema } \\
\text { para o consumidor. }\end{array}$ \\
\hline $\mathbf{E m}$ & $\begin{array}{l}\text { A empresa ressalta a importância do HACCP, implantado desde } 1998 \text { nas } \\
\text { granjas, na distribuição para o mercado interno, na logística e em todos os } \\
\text { segmentos dentro da empresa, focando sempre o consumidor final e a segurança } \\
\text { alimentar. As certificações como a EFSIS e a ISO, implantada em duas unidades, } \\
\text { ajudaram na qualidade, mas não o fazem por si só.Contribuíram no sentido de } \\
\text { ajudar a empresa a enxergar melhor a qualidade, buscando-a cada vez mais, o que } \\
\text { muda a percepção desse conceito. Trabalhar com essa questão já se prolonga há } \\
\text { mais de quatro anos na empresa e acabou mudando a consciência das pessoas. } \\
\text { Começar um programa de qualidade e mudar a cultura da empresa para uma } \\
\text { cultura de qualidade foi uma exigência feita pelos fundos de pensão, no ato da } \\
\text { compra da empresa. }\end{array}$ \\
\hline Em & $\begin{array}{l}\text { O principal é a rastreabilidade, que é um programa completo: sabe-se desde as } \\
\text { origens do frango, o horário que ele foi abatido, o alimento que ele comeu, etc. } \\
\text { No entanto, foram tomadas outras medidas com relação aos nutrientes, a } \\
\text { alimentação, ao campo. }\end{array}$ \\
\hline
\end{tabular}

Quadro 12 - Existem outras medidas importantes que a empresa adotou para satisfazer os clientes no que diz respeito à segurança dos alimentos fabricados?

Fonte: Dados da pesquisa.

No Quadro 13 estão as opiniões das empresas em relação à análise laboratorial do frango que é exportado e do modo como MAPA deveria proceder. 


\begin{tabular}{|c|c|}
\hline Empresa & Respostas \\
\hline Empresa A & $\begin{array}{l}\text { No que se refere a análise de nitrofurano, a UE está fazendo testes em } 100 \% \text { dos } \\
\text { containeres que chegam. Os laboratórios das universidades de Santa Catarina ou } \\
\text { do Rio de Janeiro fazem as análises e garantem à empresa que o produto está } \\
\text { dentro das especificações. Na Europa, a análise do nitrofurano é demorada, o que } \\
\text { retarda a liberação do contâiner. Por exemplo, um contâiner que fica aguardando } \\
30 \text { dias até sair o resultado das análises custa para a empresa ou para o } \\
\text { importador US } \$ 6.000 \text {. Tendo-se os resultados das análises realizadas no Brasil } \\
\text { daquele container, não seria necessário realizar outra análise. A empresa sugere o } \\
\text { seguinte procedimento: escolher um contâiner da empresa por mês para ver se } \\
\text { está dentro dos padrões e em caso do teste ser positivo (ou seja, acusa a presença } \\
\text { de resíduo de nitrofurano), fazer a análise em } 100 \% \text {. Quando não apresentar mais } \\
\text { casos positivos, voltar ao processo normal de } 1 \text { contâiner por mês. Essas análises } \\
\text { poderiam ser feitas no Brasil sob a supervisão do MAPA, pois como a empresa } \\
\text { que tem o SIF é obrigada a ter os veterinários do MAPA, eles próprios poderiam } \\
\text { aprovar o produto para exportar, emitindo a certificação, não necessitando de } \\
\text { testes realizados na UE. Dessa forma, o MAPA poderia interceder, não deixando } \\
\text { o problema entre a empresa e a Comunidade Européia. Isso facilitaria as } \\
\text { exportações e diminuiria os custos para o importador e para a empresa. }\end{array}$ \\
\hline Empresa C & $\begin{array}{l}\text { As análises de laboratórios podem ser separadas em: microbiológica, físico- } \\
\text { química (de resíduos, também) e sensorial. Todas as unidades da empresa têm } \\
\text { laboratórios de análise microbiológica onde é realizado o controle da higiene, da } \\
\text { contaminação do produto dentro da unidade. A físico-química agrega as análises } \\
\text { de quantidade de água, de proteína e de gordura que irão compor a característica } \\
\text { do produto. Também são realizadas análises de resíduos com a de pesticida e } \\
\text { hormônio. Para a análise de nitrofurano, a empresa está utilizando um laboratório } \\
\text { que é o mesmo laboratório que faz as análises para o Ministério. E finalmente, a } \\
\text { sensorial, que acompanha a qualidade do produto como a degustação, o sabor, } \\
\text { textura e a aparência. Atualmente o MAPA já aceita a análise de nitrofurano da } \\
\text { empresa como sendo oficial e seria muito interessante se a Europa aceitasse esta } \\
\text { análise como definitiva. A empresa questionou ao MAPA e a ABEF para reduzir } \\
\text { de } 100 \% \text { as inspeções para } 20 \% \text { É importante lembrar que cada análise na } \\
\text { Europa custa em torno de US } \$ 350,00 \text {. No entanto, o que custa mais caro é o } \\
\text { tempo que se perde na espera do resultado: cada análise destas demora de } 10 \text { a } 15 \\
\text { dias para ficar pronta, e o contâiner fica parado, custando US\$ } 1.200,00 \text { a quase } \\
\text { US } \$ 2.000,00 \text { mais caro para a empresa. Seria uma maneira de reduzir os custos e } \\
\text { liberar o contâiner mais rápido para o cliente. Sabe-se que isso constitui-se } \\
\text { barreira para a exportação e do ponto de vista da saúde pública já se sabe que são } \\
\text { mínimos os resíduos encontrados em nossos produtos. }\end{array}$ \\
\hline Empresa H & $\begin{array}{l}\text { As análises estão sendo realizadas em } 2 \text { níveis no Brasil e na UE ambos são } \\
\text { pagas pela empresa. Evidentemente, por razões de confiabilidade e de custos, a } \\
\text { empresa gostaria que as análises fossem feitas no Brasil. }\end{array}$ \\
\hline
\end{tabular}

Quadro 13 - A análise das especificidades do frango (inteiro e em cortes) exportado é realizada na UE? A empresa acha que essa análise deveria ser feita no Brasil, sob a supervisão do MAPA ou em laboratórios credenciados pelo MAPA?

Fonte: Dados da pesquisa. 
As respostas das empresas no que se refere ao relacionamento das mesmas com seus respectivos fornecedores de grãos estão no Quadro 14.

\begin{tabular}{|c|c|}
\hline Empresa & Respostas \\
\hline Empresa A & $\begin{array}{l}\text { A empresa possui fornecedores de soja, importa farelo de soja e de milho e } \\
\text { compra também de empresas grandes. Essas empresas das quais são adquiridas as } \\
\text { matérias-primas enviam relatórios desses produtos que estão vendendo. Do } \\
\text { produto que chega na fábrica de rações é coletada uma amostra semanalmente e } \\
\text { analisada para verificar se está dentro dos padrões exigidos pela empresa. Caso a } \\
\text { matéria-prima não esteja dentro dos padrões exigidos ela é devolvida para a } \\
\text { fornecedora. Atualmente o processo de compra de matéria-prima continua da } \\
\text { mesma forma. }\end{array}$ \\
\hline Empresa C & $\begin{array}{l}\text { A empresa tem as unidades de compra de grãos e eles trabalham com contratos. } \\
\text { Se é um fornecedor antigo, existe uma parceria, pois já se conhece um pouco da } \\
\text { produção das cooperativas. Se não tiver grãos geneticamente modificados, a } \\
\text { cooperativa tem de fornecer um certificado constando que não há GMO - a } \\
\text { cooperativa já fez a análise daquela produção para poder emitir o certificado. } \\
\text { Caso sejam entregas de cooperativas novas, a empresa faz um controle também } \\
\text { por meio de uma amostragem para se verificar a questão do GMO. Então, existe } \\
\text { um plano que depende de cada fornecedor ou de cada tipo de fornecedor para a } \\
\text { amostragem e para se garantir que não existe GMO. Portanto, a compra de grãos } \\
\text { baseia-se em programas de certificação e no acompanhamento de fornecedores. }\end{array}$ \\
\hline Empresa H & $\begin{array}{l}\text { Para a empresa não houve alteração no relacionamento com os fornecedores de } \\
\text { grãos. As exigências de padrões de qualidade e monitorização já eram expressas } \\
\text { nos contratos com os fornecedores. }\end{array}$ \\
\hline
\end{tabular}

Quadro 14 - Como era a relação contratual entre a empresa e o fornecedor de grãos antes de 1996 (mal da vaca louca) e como é atualmente?

Fonte: Dados da pesquisa.

Constam no Quadro 15 as medidas que cada empresa tomou em relação à liberalização da safra de grãos transgênicos. 


\begin{tabular}{|c|l|}
\hline Empresa & \multicolumn{1}{|c|}{ Respostas } \\
\hline Empresa A & $\begin{array}{l}\text { Muitos clientes continuam exigindo produtos que não sejam produzidos com } \\
\text { grãos geneticamente modificados e por isso a empresa se preocupa. Dessa forma, } \\
\text { a empresa compra de fornecedores que não utilizem essa modificação genética } \\
\text { em seus produtos e para se precaver, realiza testes que comprovem qualidade dos } \\
\text { grãos comprados. Ressalta que a safra de grãos, o governo liberou, mas } \\
\text { provavelmente as próximas serão proibidas porque seria um prejuizo muito } \\
\text { grande para o Brasil caso seja decretada a liberalização da produção de } \\
\text { transgênicos. Nesse caso, a UE poderia deixar de comprar do Brasil. A UE é } \\
\text { muito precavida no que se refere a esse assunto. De repente, daqui a 10 anos o } \\
\text { consumo desses grãos pode se manifestar na forma de doenças e, como é um } \\
\text { assunto muito recente, ela se protege. }\end{array}$ \\
\hline Empresa C & $\begin{array}{l}\text { A empresa compra grãos de fornecedores que têm certificados e também faz o } \\
\text { acompanhamento de testes. Atualmente a empresa está comprando quantidades } \\
\text { de grãos do mercado do Rio Verde, Goiás, Mato Grosso porque sabe que não } \\
\text { enfrentará o que ocorre no RS. Quando a empresa compra uma carga de grãos do } \\
\text { RS precisa comprar de quem forneça certificado, procedendo da mesma maneira } \\
\text { que a Europa. Por exemplo, a Europa, quando compra da empresa, faz visitas, } \\
\text { compra tudo com certificado e caso tenha algum problema com o produto, ela o } \\
\text { repassa de volta. Do mesmo modo, se a empresa comprar uma carga e esta tiver o } \\
\text { certificado dizendo que não contém grãos geneticamente modificados, se fazendo } \\
\text { o teste for constatada a presença, a empresa devolve a carga. Além disso, se a } \\
\text { empresa se dispõe a pagar um pouco mais, ela terá garantias de estar comprando } \\
\text { algo conforme as suas especificações. }\end{array}$ \\
\hline Empresa H & $\begin{array}{l}\text { A empresa já havia adotado, desde 2001, a realização de teste rápido para } \\
\text { deteçãa de transgênicos em todas as cargas de soja recebidas nas fábricas de } \\
\text { rações. }\end{array}$ \\
\hline
\end{tabular}

Quadro 15 - Quais as medidas adotadas pela empresa quando o governo decretou a liberalização da safra de grãos transgênicos 2002/03 no Brasil (porque a UE proíbe seu uso na ração)?

Fonte: Dados da pesquisa.

O Quadro 16 trata do relacionamento da empresa entrevistada com seus fornecedores de premix.

\begin{tabular}{|c|l|}
\hline Empresa & \multicolumn{1}{|c|}{ Respostas } \\
\hline Empresa A & $\begin{array}{l}\text { As grandes empresas produzem seu próprio premix, aquelas que não o produzem } \\
\text { possuem parcerias com esses fornecedores para que fornecem o produto } \\
\text { conforme a exigência da empresa. Os fornecedores de premix estão } \\
\text { constantemente na empresa verificando os resultados em lotes, fazendo análises } \\
\text { para verificar se a solicitação da empresa está correspondendo corretamente. }\end{array}$
\end{tabular}


\begin{tabular}{|l|l|} 
Empresa C & $\begin{array}{l}\text { Atualmente a fornecedora de premix o produz o premix e devolve para a } \\
\text { empresa, de acordo com a fórmula dada, com data e código de controle - para } \\
\text { caso de necessidade é possivel voltar e saber o que a empresa comprou e forneceu } \\
\text { para a empresa de premix. Toda a matéria-prima que será utilizada para a } \\
\text { formulação do premix é comprada pela empresa e repassada para a fornecedora. } \\
\text { Ressalta que o premix seria o "detalhe de ouro" da produção, que ainda recebe a } \\
\text { vitamina e o mineral. Resumindo é o que faz o frango crescer da maneira que a } \\
\text { empresa quer. Acrescenta-se que a empresa não faz o próprio premix por não ter } \\
\text { os equipamentos de uma fornecedora Dessa forma, a empresa seria obrigada a } \\
\text { montar uma fábrica. }\end{array}$ \\
\hline Empresa H & $\begin{array}{l}\text { As exigências de padrões de qualidade e monitorização já eram expressas nos } \\
\text { contratos com os fornecedores. Houve aumento do nível de exigência adaptando- } \\
\text { se às leis européias relacionadas à proibição de nitrofuranos e metais pesados. }\end{array}$ \\
\hline
\end{tabular}

Quadro 16 - Como era a relação contratual entre a empresa e o fornecedor de premix antes de 1996 (mal da vaca louca) e como é atualmente?

Fonte: Dados da pesquisa.

Finalizando os estudos de caso, o Quadro $17^{23}$ apresenta maiores detalhes das mudanças contratuais ocorridas entre a empresa com o seu cliente europeu, com o seu produtor de aves, o seu fornecedor de grãos e de premix.

\begin{tabular}{|c|c|}
\hline Empresa & Respostas \\
\hline Empresa A & Esta empresa não respondeu ao e-mail. \\
\hline Empresa C & $\begin{array}{l}\text { empresa e clientes europeus: junto aos clientes compradores de aves não existem } \\
\text { contratos específicos, mas sim o que chamamos internamente de "proforma } \\
\text { invoice", isto é, uma prévia da fatura, onde todos os detalhes do produto estão } \\
\text { inclusos como a descrição do item, tipo de embalagem, volume a ser embarcado, } \\
\text { forma de pagamento e outros. Em alguns casos, incluem o item vegetariano, pois } \\
\text { muito é produzido como PPE - pedido para estoque, isto é, produto produzido } \\
\text { sem cliente final; } \\
\text { empresa e produtor de aves: a empresa possui um termo de compromisso onde o } \\
\text { produtor rural de compromete em seguir as instruções e procedimentos } \\
\text { determinados pela empresa. No Anexo } 1 \text { segue o Termo de Compromisso } \\
\text { utilizado pela empresa devido ao nitrufurano. }\end{array}$ \\
\hline Empresa H & $\begin{array}{l}\text { empresa e clientes europeus: estes clientes passaram a realizar freqüentes } \\
\text { auditorias na produção (inclusive de aves vivas e rações) exigindo códigos de } \\
\text { práticas como ACP Standards, RUMA e Welfare audit. Também exigem o } \\
\text { HACCP nas plantas de abate e processamento. Em relação às multas contratuais, } \\
\text { essas só existem quando um contrato não é cumprido. O que existe é a seleção }\end{array}$ \\
\hline
\end{tabular}

${ }^{23}$ As respostas desta questão foram obtidas por e-mail enviado em 31 out. 2003. 
\begin{tabular}{|l|l|} 
durante o período de negociação. Nesta fase é importante estar em conformidade \\
com as exigências dos clientes para realizar o negócio. Cópia do Termo de \\
Garantia consta no Anexo 2. \\
empresa e fornecedor de grãos: o nível de exigência continua alto (qualidade de \\
grãos, contratos de fornecimento e garantias quanto aos grãos transgênicos); \\
empresa e fornecedor de premix: cópia do Termo de Compromisso de Premix e o \\
Termo de Garantia constam nos Anexos 3 e 4. \\
empresa e produtor de aves: foram incluídas cláusulas de responsabilidade nos \\
contratos com os integrados. \\
A empresa trabalha exclusivamente com o sistema de integração. Neste sistema, \\
a empresa fornece os pintos (de produção própria), a ração (de produção própria), \\
a assistência técnica (por técnicos de empresa), os medicamentos (comprados \\
pela empresa) e o transporte (em caminhões contratados pela empresa) ao \\
produtor rural (integrado). Resumindo, os frangos e todos os insumos são da \\
empresa. Ao produtor rural, cabe entrar com o aviário e equipamentos que devem \\
seguir o padrão da empresa que, freqüentemente são financiados pela mesma) e \\
toda mão-de-obra para a criação das aves. Portanto, o vínculo do integrado com a \\
empresa é por contrato. Cópia do contrato financeiro e operacional consta no \\
Anexo 5.
\end{tabular}

Quadro 17 - Detalhe as mudanças contratuais que ocorreram entre a empresa com o seu cliente europeu, com o seu fornecedor de grãos e de premix.

Fonte: Dados da pesquisa. 


\section{CONCLUSÕES}

Esta pesquisa visou estudar empiricamente o posicionamento da indústria avícola brasileira frente às restrições do consumidor europeu e teve como principal constatação as mudanças contratuais ocorridas entre a indústria avícola e seus fornecedores de premix e de grãos, levando-se em consideração as exigências do consumidor europeu quanto à qualidade do alimento.

A pressuposição inicial deste estudo confirma-se quanto ao nível de preocupação dos clientes europeus em relação à segurança do alimento. $\mathrm{O}$ nível de preocupação mostrou-se altíssimo (média 4, numa escala de 0-4), para 4 tipos de clientes: indústria, supermercado, restaurante, traders. Por outro lado, observou-se que o cliente menos preocupado é o atacadista, com média de 2,8 .

Em relação aos programas de qualidade empregados pelas empresas avícolas, verificou-se que $100 \%$ dos clientes indústria, processador, supermercado, restaurante e trader exigem os programas Análise de Riscos e Pontos Críticos de Controle (HACCP), Boas Práticas de Fabricação (BPF), Procedimento Padrão de Sanitização e Higiene Operacional (SSOP). Os programas ISO 9000 e Rastreabilidade, em todas as fases de criação animal, na produção de rações, no abate e no processamento são exigidos por $100 \%$ dos clientes indústria, supermercado, restaurante e trader. Esses programas citados são exigidos por $83,33 \%$ dos clientes processadores. Verificou-se que $60,0 \%$ dos clientes atacadistas, $17,64 \%$ dos distribuidores e $14,28 \%$ dos gerais não exigem a implantação do sistema de rastreabilidade. É importante ressaltar que o sistema 
de rastreabilidade ainda não é uma exigência oficial da União Européia. No entanto, as empresas estão se adiantando quanto à sua implantação.

Dentre as exigências dos clientes europeus quanto à matéria-prima, considerando-se os dados agrupados dos 41 clientes, destaca-se a proibição do uso de ingredientes de origem animal e de promotores de crescimento, com freqüência de 24 e 22 , o que representa $58,53 \%$ e $53,65 \%$, respectivamente. As outras exigências listadas foram: não usar aditivos, não usar grãos geneticamente modificados e não usar antibióticos, aproximando-se das citadas anteriormente, com 48,78\%, 43,90\% e 39,02\%, respectivamente. Outras exigências feitas pelos clientes, e citadas na opção "outra", com taxa de 24,39\%, foram: não usar determinados compostos como nitrofurano, clorofenicol e outros do plano nacional de controle de resíduos biológicos. Acrescentase também que os clientes da empresa B exigem que somente sejam utilizados promotores de crescimento, antibióticos e aditivos permitidos pela UE.

As medidas que as empresas avícolas exportadoras tomaram para atender seus clientes europeus, com taxa de $85,36 \%$, foram: assegurar-se das fontes de matériaprima e também da implantação de programas de qualidade. A implantação do sistema de rastreabilidade na empresa também teve destaque no atendimento de $75,61 \%$ dos clientes. Os investimentos em pesquisa e tecnologia e a contratação de mão-de-obra especializada tiveram as freqüuencias mais baixas (20 e 19), mas foram expressivas, com $48,78 \%$ e $46,34 \%$, respectivamente.

Observou-se que $100 \%$ das empresas adquiriam a matéria-prima frango, antes de 1996, via contrato integrado e, atualmente, $100 \%$ das empresas continuam comprando da mesma forma. Verifica-se, dessa forma, a presença da forma híbrida como estrutura de governança prevalecente na compra da matéria-prima frango, por parte da indústria avícola brasileira. 
O relacionamento de 8 empresas com seus respectivos fornecedores de grãos é distinto em cada uma delas. Observou-se que 37,5\% das empresas compravam grãos via mercado e que, após a intensificação da legislação européia com relação à proibição do uso de grãos geneticamente modificados, as mesmas afirmam que nada mudou, indicando um equívoco de conceitos. Conforme a Teoria da Economia dos Custos de Transação, a estrutura de governança, com a opção de "compra no mercado" explica que a sinalização de preços é suficiente para controlar o mercado. No entanto, uma vez adquiridos de seus fornecedores, as empresas exigem que os grãos sejam nãotransgênicos. Trata-se, mais precisamente, de um ativo altamente específico.

Verifica-se, portanto, que o conceito sobre a opção "compra no mercado", segundo a Teoria da ECT, difere daquele adotado pelas empresas. Acredita-se que a pessoa que respondeu ao questionário desconheça a teoria e considere vigente o método "compra no mercado", quando na verdade, trata-se de um relacionamento contratual, conforme verificado posteriormente nos estudos de caso.

Nos estudos de caso, foi possível aprofundar-se essa questão, verificandose que existem cláusulas contratuais estabelecidas entre as empresas e os fornecedores de grãos. São realizados testes e se a carga não estiver em conformidade com as especificidades contidas no contrato, a mesma é devolvida.

Conforme os resultados obtidos com os questionários, duas empresas compravam grãos via contrato integrado; outra, via mercado e fornecedor cadastrado e outra ainda, com contrato feito com cooperativas, continuando assim atualmente. Somente uma empresa passou a comprar grãos por meio de contrato integrado com cooperados. Percebeu-se, pelos estudos de caso, que a empresa que comprava no mercado e de fornecedor cadastrado, também realiza testes para se assegurar da origem dos grãos. Os grãos são comprados de uma grande empresa de grãos. Portanto, apesar de não terem sido constatadas, no questionário, mudanças na estrutura de governança, salvo 
uma exceção, pode-se afirmar que ocorreram mudanças contratuais, prevalecendo a estrutura híbrida.

Observou-se, dentre as empresas que responderam ao questionário, que nenhuma produz o seu próprio premix, o qual é comprado de uma empresa que o prepara conforme as exigências de cada cliente. Pelas respostas, percebe-se que $50 \%$ das empresas compravam o premix com contrato e ainda mantém essa forma atualmente. Os outros casos, como a compra no mercado e o fato de não terem havido mudanças mostra que o fato de a própria empresa não produzir seu premix significa dizer, de acordo com a pessoa que respondeu, que a compra é feita via mercado. Entretanto, percebe-se novamente que há uma discrepância entre o que a pessoa entende por compra via mercado e os conceitos da Teoria da ECT. Posteriormente, nos estudos de caso, verificou-se que a fórmula do premix é passada para a fornecedora do mesmo e ela o produzirá conforme as especificidades do contrato. Salienta-se que cada cliente exige que a empresa avícola produza o frango conforme suas exigências e dentro destas, encontra-se também o premix. Ou seja, os fornecedores precisam atingir o padrão requisitado pela empresa avícola.

Portanto, contrastando-se os resultados dos questionários, destaca-se que a estrutura de governança prevalecente no relacionamento entre a empresa avícola e a fornecedora de premix caracteriza-se como híbrida.

Assim, não se rejeita a hipótese proposta nesse trabalho, em que se esperava que as exigências do consumidor europeu fizessem com que a indústria avícola brasileira procurasse se adequar a elas e que garantissem a qualidade dos alimentos que produzem, utilizando formas contratuais mais restritivas com seus fornecedores.

Os principais pontos fracos do do questionário empregado estão relacionados com a sua própria estrutura, o qual envolvia questões pertinentes a vários setores, de modo que o entrevistado precisava se deslocar para poder responder as 
questões. Admite-se que o ideal nesse tipo de estudo seria a realização de entrevistas individuais, o que proporcionaria melhor qualidade das respostas. No entanto, procurouse preencher essa lacuna com três estudos de caso.

Como sugestão para futuros trabalhos relacionados com a cadeia produtiva do frango de corte brasileira, estariam estudos sobre as exigências de outros importantes mercados importadores como a China, Rússia e Arábia Saudita. 
ANEXOS 
ANEXO A - Termo de garantia sobre nitrofuranos da Empresa C.

Dear Mister Integrated:

We hereby inform you that due to restrictions, prohibitions and impediments of the domestic and international market and of specific standards relative to the use and prohibition of products of veterinary use, we hereby reiterate the terms of the partnership executed between you and XXXX, that we permit only the sole and exclusive use of products that are, or may be, prescribed by the veterinarian physicians of XXXXX and supplied by this company, for the therapeutic treatment of animals relative to the partnership.

Therefore, we hereby reaffirm the prohibition of purchase and use of any veterinarian products either acquired or obtained from third parties, without the previous knowledge of XXXXX and a written approval by its professionals, as well as the prohibition of the entering and permanence of third parties in the local where the animals are kept, object of the partnership or destined to sale by XXX, without previous authorization from this Company.

We hereby inform you that if our Company establishes or observes positively that you are practicing or have practiced acts that are to the contrary of this communication, this will cause the immediate termination of our partnership agreement, giving XXX the right to charge the contractual fine provided in said agreement, as well as to charge any occurred losses or damages.

Accepted:

Name:

Date: 
ANEXO B - Termo de garantia da Empresa $\mathbf{H}$.

A Empresa garante a fabricação do produto , obedecendo as normas de Boas Práticas de Fabricação e conforme abaixo:

- O Produto será produzido com base nas fórmulas registradas no Ministério da Agricultura Pecuária e Abastecimento (MAPA) e aprovadas pela NNNNN.

- Os níveis de inclusão dos componentes e princípios ativos deverão estar de acordo com a formulação.

- Os fornecedores de matéria- prima e produtos, deverão estar aprovados pela NNNNN.

- O Produto deve ser isento de resíduos de outros princípios ativos estranhos à formulação, principalmente drogas constantes do Anexo IV do Regulamento 2377/90 da União Econômica Européia (UEE) .

- O produto está registrado no MAPA sob $n^{\circ}$ (cópia do registro em anexo)

- O produto está registrado na UEE sob $n^{\circ}$ (cópia do registro em anexo)*

- O produto está registrado em (país) sob $\mathrm{n}^{\circ}$ (cópia do registro em anexo)*

Assumimos a responsabilidade do fornecimento do produto , conforme termo de garantia, caso ocorra algum prejuízo a NNNNN, pelo não cumprimento deste termo, à mesma será ressarcido. de de 2003.

pela Empresa fornecedora

$\left.{ }^{*}\right)$ no caso de não haver registro na UEE ou outros países anular a linha. 
ANEXO C - Termo de fornecimento de premix.

A Empresa NNNNNNN garante o fornecimento de premix no período de Dezembro/02 à Abril/03 para a NNNNNNN, de acordo com os termos abaixo relacionados.

\section{1) FRETE:}

Na condição CIF, deve ser observado os seguintes pontos:

- Os caminhões que farão o transporte não podem ser do tipo "BAÚ", com exceção da filial de $X$.

- O premix não pode ser transportado junto a produtos de origem animal.

- A carroceria deve estar em perfeito estado, bem como a lona, para evitar a entrada de umidade.

- Devem chegar na filial que solicitou o premix, até às 14 hs da data marcada para descarga.

\section{2) CARREGAMENTO:}

- Não serão aceitas diferenças entre o conteúdo da Nota Fiscal e a quantidade enviada/recebida.

- Para as unidades de X e X, o produto deve ser acondicionado em Pallets e envolto com microfilme plástico.

- Separar os produtos por tipo de premix, evitando pallets com diferentes tipos. Caso necessário juntar dois ou mais, separá-los com camadas de papelão e identificar conteúdo do pallet.

3) EMBALAGEM: 
- Sacos plásticos, opacos e resistentes (de modo que não permitam a passagem de luminosidade), ou multifolhados com camada plástica.

- Os sacos deverão apresentar um padrão de peso.

- Apresentar sistema de cores na sacaria e nos rótulos, possibilitando identificação visual da espécie animal e fase de crescimento.

- O tipo de costura não deve permitir a passagem de umidade e/ou vazamento de produto.

- No rótulo deverá constar o número da fórmula (referência NNNNNNN), data de fabricação e número do lote.

\section{4) PRODUTO:}

- Qualquer alteração no produto (veículo, embalagem, antioxidante, coloração, granulometria e qualquer outra matéria-prima integrante do premix) deve ser comunicado antes da chegada do mesmo à NNNNNNN.

- O produto não poderá conter grumos ou qualquer presença de materiais estranhos, sob pena de devolução do mesmo sem prévio aviso.

- Deverá ser fornecido uma relação dos fornecedores por matéria prima.

- A inclusão de matérias-primas não listadas só poderá ocorrer mediante prévia aprovação da NNNNNNN.

- Todos os microminerais devem ser utilizados na forma de sulfato, com exceção do óxido de zinco.

- Os antioxidantes aprovados para utilização nas fórmulas de premixes da NNNNNNN são: etoxiquina, feedox, endox, sinox, seldox, banox e luctanox.

- Os premixes que possuírem vitamina $\mathrm{C}$ na composição, a mesma deverá ser na forma revestida.

- O cromo utilizado em algumas fórmulas deve ser de origem orgânica. 


\section{5) FATURAMENTO:}

- Na Nota Fiscal deverá constar o número dos lotes, dos premixes que estão vinculados à ela.

6) ALTERACÃO DE FÓRMULAS:

As alterações de fórmulas deverão seguir uma rotina, que será a seguinte:

- Por ocasião do fechamento da negociação, o fornecedor deverá enviar uma relação com todas as matérias primas que compõem os premixes, com seus respectivos preços à vista, sem ICMS, FOB/SP.

- Antes de qualquer alteração, deverá ser acertado com o setor de Compras, primeiramente o preço das matérias primas que estão entrando na fórmula, para após realizar o faturamento do produto.

- Preço novo do premix = Preço anterior - Matéria prima de saída + Matéria prima de entrada.

- Qualquer alteração na fórmula solicitada pela NNNNNNN deverá ser possível dentro de 03 dias.

\section{7) CONTROLE DE QUALIDADE:}

O fabricante deverá conter rastreabilidade no seu processo, e pelo menos duas vezes por mês deverá ser enviada junto à Nota Fiscal o teste de rastreabilidade de dois Batchs diferentes.

Mensalmente deverá ser enviado à NNNNNNN os laudos internos de análises vitamínicas e minerais, realizadas pelo fornecedor nos lotes entregues à NNNNNNN. 
Será exigido do fornecedor um programa de análises de premix (vitaminas e minerais) a ser realizado em laboratório aprovado conjuntamente, e seguindo o cronograma abaixo:

- Metais Pesados: Chumbo, Cádmio, Arsênico e Mercúrio.

Uma amostra aleatória por entrega coletada pela NNNNNNN no momento da recepção do premix. Também será solicitado uma amostra mensal em ração.

- Microminerais: Zinco, Cobre, Iodo, Manganês, Ferro, Selênio e Cobalto.

Duas amostras mensais, coletada aleatoriamente no momento da recepção do premix.

- Vitaminas:

Será coletada uma amostra aleatoriamente na recepção de cada entrega, ou seja, quatro amostras mensais com análise de três vitaminas por amostra.

\section{Obs.:}

Do fornecedor aprovado na cotação será exigido o envio de uma listagem das fórmulas utilizadas para a produção.

Assumimos a responsabilidade do fornecimento do premix conforme Termo de Fornecimento de Premix.

O não cumprimento do Termo de Fornecimento de Premix e do Termo de Garantia, dará plena liberdade ao contratante em romper o contrato. 
ANEXO D - Termo de garantia para fabricação de premix.

A Empresa NNNNNNNNNNNNN garante a fabricação de Premix, obedecendo as normas de Boas Práticas de Fabricação de Premix e conforme abaixo:

- O Premix será produzido com base nas fórmulas aprovadas pela NNNNN.

- Os níveis de inclusão de vitaminas, minerais e princípios ativos, deverão estar de acordo com a formulação.

- Os fornecedores de matéria-prima e produtos, deverão estar aprovados pela NNNNNN.

- O Premix será produzido isento de resíduos de outros princípios ativos, principalmente drogas.

- Garante níveis máximos de metais pesados nos premixes :

$$
\begin{aligned}
& \text { Arsênico Máx. }=0,50 \mathrm{mg} / \mathrm{kg} \quad \text { Cádmio Máx. }=0,50 \mathrm{mg} / \mathrm{kg} \\
& \text { Chumbo Máx. }=30,00 \mathrm{mg} / \mathrm{kg} \text { Mercúrio Máx. }=0,30 \mathrm{mg} / \mathrm{kg}
\end{aligned}
$$

Assumimos a responsabilidade do fornecimento do Premix, conforme termo de garantia, caso ocorra algum prejuízo a NNNNNN, pelo não cumprimento deste termo, à mesma será ressarcido. 
ANEXO E - Contrato de colaboração financeira e operacional NNNNNNN

Objetivando o incremento da produção avícola no Estado X, pelo que representa de importância na economia brasileira para o mercado interno e expansão das exportações;

Objetivando associar interesses da NNNNNNN e de produtores rurais, ofertando a estes, nova e rentável atividade em suas propriedades;

Objetivando que os resultados econômicos se distribuam na exata proporcionalidade da colaboração ao projeto;

Objetivando a reunião dos resultados financeiros aos aspectos sociais, pela oferta da atividade ao grupo familiar, com repercussões expressivas na elevação da renda e valorização da propriedade;

A NNNNNNN estabelece o presente contrato de colaboração financeira e operacional, pelas cláusulas e condições a seguir estipuladas:

Primeiro Contratante: NNNNNNN, pessoa jurídica de direito privado, sediada na $\mathrm{X}$, no município de $\mathrm{X}$, inscrita no CNPJ sob $\mathrm{n} .{ }^{\circ} \mathrm{X}$; doravante denominado NNNNNNN NNNNNNN.

Segundo Contratante: NNNNNNNNNNN, brasileira, casada, agricultora, residente e domiciliada na localidade $\mathrm{X}$, município de $\mathrm{X}$, inscrito no $\mathrm{CPF}$ sob o $\mathbf{n}^{\circ} \mathrm{X}$, a partir de agora chamado de PRODUTORA RURAL.

Do Objeto do Presente Contratual

\section{Cláusula Primeira:}

O presente ajuste contratual objetiva o estabelecimento de criação integrada de aves, pelo sistema de parceria avícola, em aviário instalado em área do PRODUTOR RURAL, em modalidade de parceria avícola.

Parágrafo Primeiro:

Este contrato formaliza, também, período de integração anterior, existente entre 07/09/2000 e o dia de hoje cuja sistemática foi e segue sendo idêntica aos procedimentos clausulados no presente.

Parágrafo Segundo: 
Os contratantes dão-se plena e geral quitação do período de contrato tácito que precedeu a assinatura deste instrumento.

\section{Cláusula Segunda: Da Recíproca Participação}

Em sistema integrado com mútua colaboração, as partes ajustam o objetivo de criação avícola, em que os parceiros contratantes participam cada um pela forma seguinte: a NNNNNNN NNNNNNN fornecerá o lote de pintos, arraçoamento tecnicamente indicado para o crescimento das aves até o estágio de abate, integral fornecimento dos produtos medicamentosos necessários;

O PRODUTOR RURAL concederá para realização da atividade prevista, as instalações do aviário, empenhando sua atividade parceira adequada aos fins do processo criatório integrado, visando o atendimento alimentar e demais cuidados pertinentes às aves, diligenciando ainda na guarda dos produtos que restarem em seu poder, pela maneira indicada nas normas e regulamentos técnicos.

$\mathrm{O}$ criador integrado será o único responsável pelo apanhe $\mathrm{e}$ carregamento dos frangos das gaiolas para os caminhões, assim como, pelo descarregamento, na chegada, dos lotes até os galpões de criação. Estas atividades serão procedidas através de pessoal vinculado exclusivamente ao criador integrado que terá obrigação de arcar com os custos trabalhistas, fiscais, previdenciários, securitários, etc.

\section{Cláusula Terceira: Da Vinculação e Solidariedade}

Não há solidariedade da integradora para com o criador integrado no caso de ser esta acionada em qualquer juízo ou instância, respondendo esta acionada em qualquer juízo ou instância, respondendo o criador integrado isolamente, por demandas que lhes movam empregados, terceiros relacionados aos seus serviços e órgãos públicos fiscalizadores das condições laborais dos empregados.

Fica avencado que, caso a integradora seja acionada por funcionários do criador integrado ou por terceiros vinculados a esta última em razão do objeto deste contrato e condenada judicialmente a pagamento de importâncias de qualquer natureza, deverá o criador integrado reembolsar a integradora de todos os valores, inclusive aqueles decorrentes de cominações legais. 
Estabelecem as partes, sob pena de imediata rescisão e comunicação às autoridades competentes, que em hipótese alguma o PARCEIRO OUTORGADO poderá utilizar-se de mão-de-obra infantil em sua propriedade.

\section{Cláusula Quarta: Dos Custos Comuns}

Os custos derivados obedecerão ao sistema de pré-fixação de valores, definindo-se por lote, os preços da unidade pinto, quilograma de ração e medicamentos.

\section{Cláusula Quinta: Tecnologia e Assistência Veterinária}

Os custos decorrentes da instrução e orientação do PRODUTOR RURAL, para aplicação da avançada tecnologia a ser utilizado no sistema criatório avícola, bem como, a assistência veterinária indispensável $\mathrm{e}$ adequada à atividade parceira, será suportada pela NNNNNNN NNNNNNN, através do seu quadro profissional, sem qualquer repasse de valores.

\section{Cláusula Sexta: Do Transporte de Aves e Produtos}

A NNNNNNN NNNNNNN, através de seu setor técnico e administrativo, coordenará o transporte das aves e produtos, os quais serão realizados por transportadores autônomos ou empresas transportadoras, por ela contratada.

\section{Cláusula Sétima: Dos Resultados aos Parceiros}

O final da criação do lote de aves, atingido o estágio ideal previsto para abate, o PRODUTOR RURAL se obriga entregar à NNNNNNN, quantidade de $\mathrm{kg} /$ ave para resgate dos custos utilizados, tudo dentro dos valores pré-fixados ao início da criação.

Cláusula Oitava:

Eventuais custos extraordinários aprovados pelas partes, e adiantamentos de numerário, a título de empréstimo, serão também satisfeitos pelo PRODUTOR RURAL à NNNNNNN NNNNNNN pela entrega de kg/ave, encerrandose a conta corrente formalizada para controle dos parceiros.

Parágrafo Único: a novação de débito para satisfação em lote de criação futura será iniciativa de mera liberalidade da NNNNNNN NNNNNNN, que não acrescerá qualquer novo direito ao PRODUTOR RURAL na relação jurídica estabelecida. 
Caberá ao PRODUTOR RURAL como resultado da atividade parceira, $10 \%$ (dez por cento) das aves entregues, as quais serão remuneradas em função de seu custo de produção, resultante do somatório das despesas com arraçoamento, medicamentos e pintos, desde que resgatados os custos utilizados para a criação das aves.

Cláusula Décima:

A atividade parceira finalizará quando o PRODUTOR RURAL devolver à NNNNNNN NNNNNNN a quantidade de kg/ave suficiente para liquidação dos custos determinados e neste contratual especificados, cujos valores gerais obedecem a tabela pré-fixada.

Cláusula Décima - Primeira:

O resultado parceiro da NNNNNNN NNNNNNN estará consumado quando da devolução dos $\mathrm{kg}$ /ave para resgate de custos, que define o encerramento do período criatório. Nada mais terá a reclamar a qualquer tempo e título do parceiro PRODUTOR RURAL.

Cláusula Décima - Segunda:

O resultado do parceiro PRODUTOR RURAL será representado pelos $10 \%$ (dez por cento) das aves entregues, as quais serão remuneradas em função de seu custo de produção. Nada mais a reclamar a qualquer tempo e título da parceira NNNNNNN NNNNNNN.

Cláusula Décima - Terceira:

O lote residual de aves que pertencerem ao PRODUTOR RURAL poderá ser adquirido pela NNNNNNN NNNNNNN, a qual terá direito de preferência de aquisição.

\section{Do Fornecimento de Lotes de Pintos}

Cláusula Décima - Quarta:

O fornecimento de lotes de pintos da NNNNNNN NNNNNNN ao PRODUTOR RURAL obedecerá a critérios de capacidade, aspectos técnicos e sanitários do aviário, que será objeto de permanente apreciação pelo setor técnico da alimentadora. 
Cláusula Décima - Quinta:

A NNNNNNN NNNNNNN poderá suspender temporária e definitivamente o fornecimento de lotes de pinto e o processo criatório, independente de notificação ou aviso premonitório, pelo desatendimento do PRODUTOR RURAL às normas técnicas, até regularização, o que ensejará laudo competente, do qual constará as irregularidades acusadas, bem como, roteiro de providências para saneamento do problema constatado.

Parágrafo-Único: os insumos depositados pela parceira NNNNNNN NNNNNNN ao parceiro PRODUTOR RURAL são de uso exclusivo do processo criatório que envolve o presente contrato. $O$ desvio ou utilização indevida pelo PRODUTOR RURAL de quaisquer produtos que lhe sejam entregue pela NNNNNNN NNNNNNN em decorrência deste contrato permitirá à empresa parceira o rompimento do contrato, independente de aviso prévio e sem prejuízo de perdas e danos e lucros cessantes que possa sofrer a mesma.

Cláusula Décima - Sexta:

A NNNNNNN NNNNNNN, para proteção de mútuos interesses, poderá também, independente de notificação ou aviso premonitório, por questões operacionais ou mercadológicas, suspender por prazo temporário ilimitado o fornecimento de lotes de pintos para o processo ajustado.

\section{Da Responsabilidade Ambiental}

Cláusula Décima - Sétima:

Será de propriedade e responsabilidade única e exclusiva do parceiro PRODUTOR RURAL, o destino dos resíduos sólidos e líquidos que a atividade produzir, respondendo o mesmo perante os órgãos governamentais responsáveis pelo meio-ambiente, obrigando-se a cumprir suas legislações e normas vigentes.

“A NNNNNNN NNNNNNN compromete-se a fornecer a PRODUTOR RURAL, sob pena de rescisão contratual, orientação voltada à otimização das atividades deste em relação ao meio ambiente, e a fiscalizar a efetiva implantação das medidas recomendadas, através de seu corpo técnico, comprometendo-se o PRODUTOR RURAL, também sob pena de motivar a ruptura do contrato, a cumprir ditas 
orientações/fiscalizações relativas à geração, contenção, tratamento e deposição dos resíduos decorrentes do empreendimento de integração.

$\S^{\circ}$ - A NNNNNNN NNNNNNN poderá, unilateralmente, deixar de fornecer ração e pintos, caso o PRODUTOR RURAL descumprir o avençado no caput.

$\$ \mathbf{2}^{\circ}$ - Estabelecem as partes que, a partir de $12 / 12 / 03$, os lotes de animais e insumos somente poderão ser alojados mediante existência comprovada da cabível concessão de licença ambiental (pela FEPAM ou pelo Município onde está localizado o aviário do PRODUTOR RURAL)".

\section{Do Financiamento dos Insumos}

Cláusula Décima - Oitava:

O parceiro PRODUTOR RURAL compromete-se, na medida das necessidades que o parceiro NNNNNNN NNNNNNN estipular, a participar dos processos de financiamento dos insumos necessários ao processo criatório, ficando o parceiro NNNNNNN NNNNNNN responsável por toda a quitação de qualquer ônus advindo do referido financiamento.

\section{Do Prazo de Duração}

Cláusula Décima - Nona:

O prazo de duração do presente contrato é indeterminado, desde que rescindido por qualquer uma das partes desde que concedido, de modo expresso, préaviso de 30 dias.

\section{Da Assistência e Fiscalização à Criação}

Cláusula Vigésima:

$\mathrm{O}$ aviário deverá estar permanentemente franqueado aos técnicos credenciados da NNNNNNN NNNNNNN, para a prestação de assistência técnica ao processo criatório.

Fica terminantemente proibida a utilização de qualquer medicamento por parte do parceiro PRODUTOR RURAL sem autorização do departamento técnico da parceira NNNNNNN NNNNNNN, visto problemas biológicos que dos mesmos podem decorrer. Caso constatado e comprovado o uso indevido de medicamentos será o integrado responsabilizado pelos danos causados à parceira NNNNNNN NNNNNNN . 
Parágrafo Único: o parceiro PRODUTOR RURAL compromete-se a instalar uma placa indicativa, conforme padrão fornecido pela parceira NNNNNNN NNNNNNN, que visa facilitar a localização para as entregas dos insumos necessários ao desenvolvimento do processo criatório.

\section{Da Rescisão Contratual}

Cláusula Vigésima - Primeira:

Constituir-se-ão em razões de rescisão do ajuste operacional de criação integrada:

a) descumprimento pelas partes dos termos do presente contrato de parceria avícola;

b) recusa imotivada do PRODUTOR RURAL em receber novos lotes de pintos para criação;

c) recusa do PRODUTOR RURAL em entregar à NNNNNNN NNNNNNN, no prazo estabelecido, as aves criadas em quilogramas correspondentes aos custos debitados;

d) descumprimento pelas partes, das normas operacionais suplementares e estabelecidas entre as partes;

e) desatender o PRODUTOR RURAL às normas estabelecidas pelo setor técnico da NNNNNNN NNNNNNN;

f) promover ao PRODUTOR RURAL venda, arrendamento ou estabelecimento de parceria com terceiro, do aviário onde se realiza a criação integrada, ou comércio de qualquer natureza dos insumos necessários à criação, sem o expresso consentimento da NNNNNNN NNNNNNN.

\section{Das Conseqüências da Rescisão Contratual}

Cláusula Vigésima - Segunda:

A parte que der causa à rescisão contratual, responderá perante a outra, por perdas e danos na forma do Artigo 389 do Código Civil Brasileiro.

\section{Da Eleição de Foro}

Cláusula Vigésima - Terceira: 
As partes elegem o foro da Comarca de $\mathrm{X}$ para dirimir eventuais litígios emergentes do presente contrato.

E, por estarem justas e contratadas, na presença das testemunhas instrumentárias, assinam o presente ajuste contratual em duas vias de igual teor e forma para que surta seus jurídicos efeitos.

NNNNNNN

NNNNNNNN

TESTEMUNHAS:

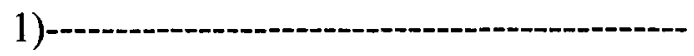

2) 


\section{REFERÊNCIAS BIBLIOGRÁFICAS}

ALIMENTO orgânico ganha, cada vez mais, espaço no mundo: notícias da redação, 29/09/2003. Avicultura industrial, notícias da redação, 29/09/2003. São Paulo: Gessulli, 2003. http://www.aviculturaindustrial.com.br (01 abr. 2003)

ALSTON, L.J. A framework for understanding the New Institucional Economics. Illinois: Univerity of Illinois, July 1998. 22p.

ARASHIRO, O. A história da avicultura no Brasil. São Paulo: CQ, 1989. 301p.

ARAÚJO, M. da. Rentabilidade da produção de frango de corte sob contratos de integração vertical em Minas Gerais. Piracicaba, 1996. 133p. Dissertação (Mestrado) - Escola Superior de Agricultura "Luiz de Queiroz", Universidade de São Paulo.

ASSOCIAÇÃO DOS EXPORTADORES BRASILEIRA DE FRANGOS. Estatísticas. htpp://www.abef.com.br (01 fev. 2003)

AZEVEDO, P.F. Concorrência no agrobusiness. In: ZYLBERSZTAJN, D.; NEVES, M.F. (Org.). Economia \& gestão dos negócios agroalimentares. São Paulo: Pioneira, 2000. cap.4, p.61-78.

BARBETTA, P.A. Estatística aplicada às ciências sociais. 5.ed. Florianópolis: Editora da UFSC, 2002.340p. 
BRASIL. Ministério do Desenvolvimento, Indústria e Comércio Exterior. Secretaria de Comércio Exterior. Indicadores e estatísticas. htpp://www.desenvolmento.gov.br (20 abr. 2003)

$\rightarrow$ BRASIL. Ministério do Desenvolvimento, Indústria e Comércio Exterior. Secretaria do Comércio Exterior. Departamento de Negociações Internacionais. Barreiras externas às exportações brasileiras. 2001. http:// www.mdic.gov.br/comext/Deint/Barreiras/UEuropa.pdf (02 fev. 2003)

BRASIL. Ministério da Agricultura, Pecuária e Abastecimento. Departamento de Inspeção dos Produtos de Origem Animal. Sigsif. http://www.agricultura.gov.br (10 maio 2003)

BRASIL. Leis, decretos, etc. Decreto n⿳0 4.680 de 24 de abril de 2003. Diário Oficial da União, 25 abr. 2003. Regulamenta o direito à informação quanto aos alimentos e ingredientes alimentares destinados ao consumo humano ou animal que contenham ou sejam produzidos a partir de organismos geneticamente modificados.

BRASIL. Leis, decretos, etc. Lei no 10.688 de 13 de junho de 2003. Diário Oficial da União, jun. 2003. Estabelece normas para a comercialização da produção de soja da safra de 2003.

BRASIL. Leis, decretos, etc. Medida Provisória 131 de 25 de setembro de 2003. Diário Oficial da União, 26 set. 2003. Estabelece normas para o plantio e comercialização da produção de soja da safra de 2004.

BRASIL. Leis, decretos, etc. Instrução Normativa nº 15 de 17 de julho de 1991. Diário Oficial da União, 17 jul. 1991. Dispõe sobre a alimentação de ruminantes com ingredientes derivados de ruminantes, revoga a Instrução Normativa ${ }^{\circ} 6$. 
BRASIL. Leis, decretos, etc. Lei no 8.974 de 05 de janeiro de 1995. Diário Oficial da União, 06 jan. 1995. Dispõe sobre Organismo Geneticamente Modificado.

BRASIL. Leis, decretos, etc. Portaria 365 de 03 de julho de 1996. Diário Oficial da União, jul. 1996. Dispõe a Encefalopatia Espongiforme Bovina (EEB).

BRASIL. Leis, decretos, etc. Portaria 290 de 16 de julho de 1997. Diário Oficial da União, 17 jul. 1997. Dispõe sobre a Encefalopatia Espongiforme Bovina (EEB), revoga a Portaria 365.

BRASIL. Leis, decretos, etc. Portaria Ministerial 516 de 09 de dezembro de 1997. Diário Oficial da União, 11 dez.1997. Declara o Brasil livre de Encefalopatia Espongiforme Bovina.

BRASIL. Leis, decretos, etc. Medida Provisória 113 de 26 de março de 2003. Diário Oficial da União, 27 mar. 2003. Dispõe sobre a comercialização de soja transgênica na safra 2002/03.

BRASIL. Leis, decretos, etc. Resolução n 7 de 10 de abril de 2003. Diário Oficial da União, 15 abr. 2003. Estabelece novos procedimentos operacionais relativos à habilitação, auditoria e supervisão de estabelecimentos habilitados ao comércio internacional de carnes, ovos e seus derivados.

BRASIL. Leis, decretos, etc. Instrução Normativa no 038 de 08 de maio de 2002. Diário Oficial da União, 08 maio 2002. Proíbe a utilização do grupo de nitrofuranos para preparação de insumos utilizados na pecuária nacional. 
BRASIL. Leis, decretos, etc. Portaria no 89 de 24 de março de 1998. Diário Oficial da União, mar. 1998. Dispõe sobre a presença de resíduos cloranfenicol, furazolidona e nitrofurazona na carne, leite e ovos, oriundos de animais tratados, podem constituir risco à saúde pública.

$\rightarrow$ CAMPANHA tenta banir ração clandestina: notícias da redação, 31/03/2003. Avicultura industrial. São Paulo: Gessulli, 2003. http://www.aviculturaindustrial.com.br (01 abr. 2003)

CANEVER, M.D.; TALAMINI, D.J.D.; CAMPOS, A.C.; SANTOS FILHO, J.I. dos. A cadeia produtiva do frango de corte no Brasil e na Argentina. Concórdia: EMBRAPA, CNPSA, 1997.150p.

CANEVER, M.D.; CHIUCHETTA, O; SANTOS FILHO, J.I. dos.; TALAMINI, D.J.D. Mudanças tecnológicas na avicultura de corte: implicações sócio-econômicas. Revista de Política Agrícola, v.3, n.1, p.9, jan./fev./mar. 1998. htpp:// www.agricultura.gov.br (03 jun. 2003)

CARLTON, D.W.; PERLOFF, J.M. Modern industrial organization. 2.ed. New York: Harper Collins College Publishers, 1994. 973p.

CERUTTI, M. Rastreabilidade na indústria avícola. Avicultura Industrial, v.93, n.1102, p.32-41, jul. 2002.

COELHO, C.N.; BORGE, M. O complexo agroindustrial (CAI) da avicultura. Revista de política agrícola, v.3, n.3, p.25, jul./ago. 1999. htpp://www.agricultura.gov.br (01 mar. 2003) 
COMUNIDADES EUROPÉIAS. Uma alimentação saudável aos cidadãos europeus: a União Européia e a qualidade alimentar. Luxemburgo: Comissão Européia/Serviço das Publicações Oficiais das Comunidades Européias, 2002. 22p. (Série a Europa em Movimento)

COMUNIDADES EUROPÉIAS. Quem é quem na União Européia. Luxemburgo: Serviço das Publicações Oficiais das Comunidades Européias, 2002. 14p.

COMISSÃO DAS COMUNIDADES EUROPÉIAS. Livro branco sobre a segurança dos alimentos. Bruxelas, 2000. COM(1999)719.

COMISSÃO DAS COMUNIDADES EUROPÉIAS. Livro verde sobre a defesa do consumidor na União Européia. Bruxelas, 2001. COM(2001) [531 final].

COMISSÃO DAS COMUNIDADES EUROPÉIAS. Livro verde sobre os princípios gerais da legislação alimentar da União Européia. Bruxelas, 1997. COM (97) [176 final].

FARINA, E.M.M.Q.; AZEVEDO, P.F. de; SAES, M.S.M. Competitividade: mercado, estado e organizações. São Paulo: Singular, 1997. 285p.

FERNANDES FILHO, J.F.; QUEIROZ, A.M. Transformações recentes na avicultura de corte brasileira: o caso do modelo de integração (compact disc). In: INTERNACIONAL CONFERENCE ON AGRI-FOOD CHAIN/NETWORKS ECONOMICS AND MANAGEMENT, 3., Ribeirão Preto, 2001. Anais. São Paulo: PENSA, 2001.

FNP CPNSULTORIA \& AGROINFORMATIVOS. Anualpec: anuário da pecuária brasileira. São Paulo, 2002. p.262: Aves e ovos.

GIL, A.C.N. Técnicas de pesquisa em economia. 2.ed. São Paulo: Atlas, 1991. 195p. 
INFORME EMBRAPA: exportação do frango brasileiro e o desafio do mercado europeu. Avicultura industrial, v.1, n.1108, p.16-17, 2003.

INTOXICAÇÃO: parte I. Avicultura industrial, v.91, n.1090, p.26-30, 2001.

JANK, M.S. A rastreabilidade nos agronegócios. In: ZYLBERSZTJN, D. (Coord.). In: SEMINÁRIO INTERNACIONAL PENSA DE AGROBUSINESS, 9., Águas de São Pedro, 1999. Cinco ensaios sobre a gestão de qualidade no agrobusiness. São Paulo: PENSA, 1999. cap.4, p. 31-42.

LAZZARINI, S.G. Estudo de caso para fins de pesquisa: aplicabilidade e aplicações do método. In: FARINA, M.M.Q. (Coord.). Estudo de caso em agrobusiness. São Paulo: Pioneira, 1997. p.9-23.

LAZZAROTTO. N. de F. Estudo sobre o mercado de certificação em alimentos. (compact disc). In: INTERNACIONAL CONFERENCE ON AGRI-FOOD CHAIN/NETWORKS ECONOMICS AND MANAGEMENT, 3., Ribeirão Preto, 2001. Anais. São Paulo: PENSA, 2001.

LOMBARDI, M.C. Rastreabilidade: exigências sanitárias dos novos mercados. In: CONGRESSO BRASILEIRO DAS RAÇAS ZEBUÍNAS, 3., Uberaba, 1998. Anais. Uberaba: ABCZ, 1998. p.90-94.

LOPES, J.E.P. Análise econômica de contratos de integração usados no complexo agroindustrial avícola brasileiro. Viçosa, 1992. 104p. Dissertação (Mestrado) Universidade Federal de Viçosa. 
MARQUES, P.V. Economia da integração vertical na avicultura de corte do estado de São Paulo. Piracicaba, 1991. 132p. Tese (Livre-Docência) - Escola Superior de Agricultura "Luiz de Queiroz", Universidade de São Paulo.

MARQUES, P.V.; AGUIAR, D.R.D. de. Comercialização de produtos agrícolas. Piracicaba: ESALQ, Depto. de Economia, Administração e Sociologia, 1989. 268p. (Série Didática, 54)

MOE, T. Perspectives on traceability in food manufacture. Science and Technology, v.9, p.211-214, 1998 .

NASSAR, A.M. Certificação no agrobusiness. In: ZYLBERSZTJN, D. (Coord.). In: SEMINÁRIO INTERNACIONAL PENSA DE AGROBUSINESS, 9., Águas de São Pedro, 1999. Cinco ensaios sobre a gestão de qualidade no agrobusiness. São Paulo: PENSA, 1999. cap.3, p.16-30.

NORTH, D.C. Institutions, institutional change and economic peformance. Cambridge: University Press, 1990. p.3-59: An introduction to institutions and institutional change.

NORTH, D.C. Institution. Jornal of Economic Perspectives, v.1, n.1, p.97-112, 1991.

PESSANHA, C. Transgênicos e segurança alimentar: o que está em jogo? Revista Eletrônica de Jornalismo Científico da UNICAMP, v.2, n.5, p.15, abr. 2003.

PROCESSAMENTO de carne: e agora? Suinocultura industrial, v.31, n.138, p.32-33, abr./maio 1999. 
RASTREABILIDADE também pode ser obrigatória para a avicultura: notícias da redação, 21/06/2002. Avicultura industrial. São Paulo: Gessulli, 2002. http://www.aviculturaindustrial.com.br (01 fev. 2003)

REJEIÇÃO dos transgênicos favorece produtos brasileiros: notícia 01/11/2001. O Estado de São Paulo. São Paulo, 2001. http://www.estado.com.br (01 jun. 2003)

REIS, A J. dos. Organização da estrutura do mercado. In: REIS, A.J. dos; CARVALHO, F.A.P. Comercialização agrícola no contexto agroindustrial. Lavras: UFLA/FAEPE, 1999. cap.5, p.189-210.

RICHETTI, A.; SANTOS, A.C. dos. O sistema integrado de produção de frango de corte em Minas Gerais: uma análise sob a ótica da ECT. Organizações Rurais e Agroindustriais. Revista de Administração da UFLA, v.2, n.2, p.34-43, jul./dez. 2000 .

ROTULAGEM deve aumentar custos do setor em 10\%: notícias da redação, 05/05/2003.

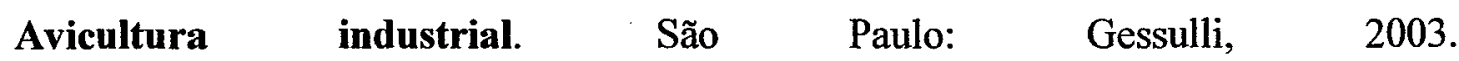
http://www.aviculturaindustrial.com.br (01 jun. 2003)

SOJA transgênica sofre críticas: notícias da redação, 31/03/2003. Avicultura industrial. São Paulo: Gessulli, 2003. http://www.aviculturaindustrial.com.br (01 abr. 2003)

SOUZA, J.P. Estratégias competitivas da indústria de carnes no período de 1990 a 1998. htpp://www.eps.ufsc/disserta.99/souza/cap4.htm (03 jun. 2003)

SORJ, B.; POMPERMAYER, M.J.; CORADINI, O.L. Camponeses e agroindústria: transformação social e representação política na avicultura. Rio de Janeiro: Zahar, 1982. 118p. 
SPERS, E.E. A segurança ao longo da cadeia agroalimentar. Conjuntura alimentos, v.5, n.1, p.18-26, fev.1993.

SPERS, E.E. Qualidade e segurança em alimentos. In: ZYLBERSZTAJN, D.; NEVES, M.F. (Org.). Economia \& gestão dos negócios agroalimentares. São Paulo: Pioneira, 2000. cap:13, p.283-315.

SPERS, E.E. Segurança do alimento. In: ZYLBERSZTJN, D. (Coord.). In: SEMINÁRIO INTERNACIONAL PENSA DE AGROBUSINESS, 9., Águas de São Pedro, 1999. Cinco ensaios sobre a gestão de qualidade no agrobusiness. São Paulo: PENSA, 1999. cap.5, p.43-68.

UE deve banir antibióticos já a partir de 2005: notícias da redação, 29/11/2002. $\begin{array}{lllll}\text { Avicultura industrial. São } & \text { Paulo: Gessulli, }\end{array}$ http://www.aviculturaindustrial.com.br (01 fev. 2003)

UE vai manter inspeções por causa do nitrofurano: notícias da redação, 27/03/2003. $\begin{array}{lllll}\text { Avicultura industrial. } & \text { São } & \text { Paulo: Gessulli, } & 2003 .\end{array}$ http://www.aviculturaindustrial.com.br (01 abr. 2003)

UNIÃO EUROPÉIA. Regulamentos, diretivas, etc. Diretiva 90/667/CEE de 27 de novembro de 1990. Jornal Oficial, dez. 1990, $\mathrm{n}^{\circ}$ L 363, p. 0051 - 0060. Estabelece as normas sanitárias para a eliminação e a transformação de resíduos animais, para a sua colocação no mercado e para a prevenção da presença de agentes patogênicos nos alimentos para animais de origem animal ou à base de peixe e que altera a Diretiva 90/425/CEE. 
UNIÃO EUROPÉIA. Regulamentos, diretivas, etc. Diretiva 92/59/CEE do Conselho de 29 de junho de 1992. Jornal Oficial, ago. 1992, $\mathrm{n}^{\mathrm{o}}$ L 228, p. 0024 - 0032. Relativa a segurança geral dos produtos.

UNIÃO EUROPÉIA. Regulamentos, diretivas, etc. Diretiva 96/22/CE de 29 de abril de 1996. Jornal Oficial, maio 1996, nº L 125, p. 0003 - 0009. Relativa à proibição de utilização de certas substâncias com efeitos hormonais ou tireostáticos e de substâncias B-agonistas em produção animal e que revoga as Diretivas 81/602/CEE, 88/146/CEE e 88/299/CEE.

UNIÃO EUROPÉIA. Regulamentos, diretivas, etc. Regulamento (CE) nº 49/2000 de 10 de janeiro de 2000. Jornal Oficial, jan. 2000, nº L 6, p. 13. Altera o Regulamento (CE) n.o 1139/98 do Conselho relativo à menção obrigatória, na rotulagem de determinados gêneros alimentícios produzidos a partir de organismos geneticamente modificados, de outras informações para além das previstas na Diretiva 79/112/CEE.

UNIÃO EUROPÉIA. Regulamentos, diretivas, etc. Diretiva 2001/18/CE de 12 de março de 2001. Jornal Oficial, abr. 2001, no L 106, p. 0001 - 0039. Relativa à libertação deliberada no ambiente de organismos geneticamente modificados e que revoga a Diretiva 90/220/CEE do Conselho - Declaração da Comissão.

UNIÃO EUROPÉIA. Regulamentos, diretivas, etc. Regulamento CE n ${ }^{\circ} 178 / 2002$ de 28 de janeiro de 2002. Jornal Oficial, fev. 2002, no L 031, p. 0001 - 0024. Determina os princípios e normas gerais da legislação alimentar, cria a Autoridade Européia para a Segurança dos Alimentos e estabelece procedimentos em matéria de segurança dos gêneros alimentícios. 
UNIÃO EUROPÉIA. Regulamentos, diretivas, etc. Decisão da Comissão 2002/248/CE de 27 de março de 2002. Jornal Oficial, mar. 2002, no L 84, p. 71. Altera a Decisão 2000/766/CE do Conselho e a Decisão 2001/9/CE da Comissão relativas às encefalopatias espongiformes transmissíveis e à utilização de proteínas animais na alimentação animal.

UNIÃO EUROPÉIA. Regulamentos, diretivas, etc. Regulamento (CE) ํำ 1774/2002 de 03 de outubro de 2002. Jornal Oficial, out. 2002, $\mathrm{n}^{\mathbf{0}}$ L 273, p. $0001-0095$. Estabelece regras sanitárias relativas aos subprodutos animais não destinados ao consumo humano.

UNIÃO EUROPÉIA. Regulamentos, diretivas, etc. Diretiva 89/107/CEE do Conselho de 21 de dezembro de 1988. Jornal Oficial, fev. 1989, № L 040, p. $0027-0033$. Refere-se à aproximação das legislações dos Estados-membros respeitantes aos aditivos que podem ser utilizados nos gêneros destinados à alimentação humana

UNIÃO EUROPÉIA. Regulamentos, Diretivas etc. O Regulamento $n^{\circ}=50 / 2000$ da Comissão, de 10 de janeiro de 2000. Jornal Oficial, jan. 2000, no L 6. Refere-se à rotulagem dos gêneros alimentícios e ingredientes alimentares que contêm aditivos e aromas geneticamente modificados ou produzidos a partir de organismos geneticamente modificados.

UNIÃO EUROPÉIA. Regulamentos, diretivas, etc. Regulamento (CE) no 999/2001 do Parlamento Europeu e do Conselho, de 22 de maio de 2001. Jornal Oficial, maio 2001, no L 147, p.0001 - 0040. Estabelece regras para a prevenção, o controle e a erradicação de determinadas encefalopatias espongiformes transmissíveis. 
UNIÃO EUROPÉIA. Regulamentos, diretivas, etc. Regulamento (CE) no 258/97 do Parlamento Europeu e do Conselho de 27 de janeiro de 1997. Jornal Oficial, jul. 1999, no L 187, p.0074 - 0074. Refere-se aos novos alimentos e ingredientes alimentares.

UNIÃO EUROPÉIA. Regulamentos, diretivas, etc. Decisão da Comissão 2002/934 de 28 de novembro de 2002. Jornal Oficial, nov. 2002, no L 324, p.0073 - 0075. Aprova programas de vigilância das encefalopatias espongiformes transmissíveis de determinados Estados-Membros para 2003 e fixa a participação financeira.

UNIÃO EUROPÉIA. Regulamentos, diretivas, etc. Diretiva 91/494/CEE do Conselho, de 26 de junho de 1991. Jornal Oficial, set. 1991, no L 268, p.0035 - 0040. Refere-se às condições de polícia sanitária que regem o comércio intracomunitário e as importações provenientes de países terceiros de carnes frescas de aves de capoeira.

UNIÃO EUROPÉIA. Regulamentos, diretivas, etc. Diretiva do Conselho 71/118/CEE de 15 de fevereiro de 1971. Jornal Oficial, mar. 1973, o L 061, p.0022. Refere-se aos problemas sanitários em matéria de comércio de carnes frescas de aves de capoeira.

VINHOLIS, M.de M.B.; AZEVEDO, P.F. de. Efeitos da rastreabilidade no sistema agroindustrial da carne bovina brasileira (compact disc). In: CONGRESSO BRASILEIRA DE ECONOMIA E SOCIOLOGIA RURAL, 38., Rio de Janeiro, 2000. Anais. Brasília: SOBER, 2000.

WILLIAMSON, O. The mecanism of governance. New York: Oxford University Press, 1996. 
WILLIAMSON, $O$. The economis institutions of capitalism: firms markets, relational contracting. New York: Free Press, 1985. 450p.

ZYLBERSZTAJN, D. Estrutura de governança e coordenação do agrobusiness: uma aplicação da Nova Economia das Instituições. São Paulo, 1995. 285p. Tese (Livre Docência) - Faculdade de Economia e Administração, Universidade de São Paulo.

YIN, R.K. Case study research, design and methods. Newbury Park: Sage Publications, 1989. 165p. 


\section{APÊNDICES}


APÊNDICE 1 - Empresas avícolas com Sistema de Inspeção Federal (SIF) por regiões e estados do Brasil.

\begin{tabular}{lccccc}
\hline & MA1* & MA2 & MA3 & MA4 & Total \\
\hline Região Sul & & & & total & 54 \\
Paraná & 6 & 3 & 13 & 1 & 23 \\
Santa Catarina & 6 & 0 & 5 & 2 & 13 \\
Rio Grande do Sul & 7 & 4 & 4 & 3 & 18 \\
Região Sudeste & & & & total & 75 \\
São Paulo & 6 & 10 & 27 & 8 & 51 \\
Rio de Janeiro & 0 & 0 & 0 & 0 & 0 \\
Minas Gerais & 3 & 5 & 10 & 3 & 21 \\
Espírito Santo & 0 & 1 & 1 & 1 & 3 \\
Região Centro-Oeste & & & & total & 17 \\
Mato Grosso do Sul & 2 & 0 & 1 & 2 & 5 \\
Mato Grosso & 1 & 0 & 1 & 2 & 4 \\
Goiás & 2 & 0 & 4 & 1 & 7 \\
Distrito Federal & 1 & 0 & 0 & 0 & 1 \\
Região Norte & & & & total & 4 \\
Acre & 0 & 0 & 0 & 0 & 0 \\
Amazonas & 0 & 0 & 0 & 0 & 0 \\
Rondônia & 0 & 1 & 0 & 0 & 1 \\
Pará & 0 & 0 & 2 & 1 & 3 \\
Tocantins & 0 & 0 & 0 & 0 & 0 \\
Roraima & 0 & 0 & 0 & 0 & 0 \\
Amapá & 0 & 0 & 0 & 0 & 0 \\
Região Nordeste & & & & total & 10 \\
Bahia & 0 & 1 & 1 & 0 & 2 \\
Sergipe & 0 & 0 & 0 & 0 & 0 \\
Alagoas & 0 & 0 & 0 & 0 & 0 \\
Piauí & 0 & 0 & 1 & 0 & 1 \\
Pernambuco & 0 & 1 & 3 & 3 & 7 \\
Paraíba & 0 & 0 & 0 & 0 & 0 \\
Ceará & 0 & 0 & 0 & 0 & 0 \\
Rio Grande do Norte & 0 & 0 & 0 & 0 & 0 \\
Maranhão & 0 & 0 & 0 & 0 & 0 \\
Total Brasil & 34 & 26 & 73 & 27 & 160 \\
\hline Fonte Brasi (2003) & & & & & \\
\hline
\end{tabular}

Fonte: Brasil (2003)

* Conforme a Portaria $n^{\circ} 82$ de 27 de fevereiro de 1976, estabelece, entre outras medidas que, os estabelecimentos de empresas avícolas são classificadas conforme a capacidade de abate a saber: MA1- abater mais de 3.000 cabeças por hora; MA2 - entre 1.500 e $3.000 / \mathrm{h}$; MA3 - 600 a $1.500 / \mathrm{h}$ e MA4 até $600 / \mathrm{h}$. 
APÊNDICE 2 - Empresas habilitadas a exportar para a União Européia (em vigor a partir de 03/02/2003).

\begin{tabular}{|c|c|c|}
\hline Santa Catarina & Município & Atividades \\
\hline 1 Sadia S/A & Concórdia & $\mathrm{CP}, \mathrm{SH}$ \\
\hline 2 Perdigão Agroinduistrial S/A & Videira & $\mathrm{CP}, \mathrm{SH}$ \\
\hline 3 Sadia S/A & Chapecó & $\mathrm{CP}, \mathrm{SH}$ \\
\hline 4 Braskarne Armazéns Gerais Ltda & Itajaí & CS \\
\hline 5 Perdigão Agroindistrial S/A & Capinzal & $\mathrm{CP}, \mathrm{SH}$ \\
\hline $\begin{array}{l}6 \text { Bomfrio - Serviços de Armazém Frigorificada } \\
\text { Ltda }\end{array}$ & Chapecó & CS \\
\hline 7 Seara Alimentos Ltda & Itapiranga & $\mathrm{CP}, \mathrm{SH}$ \\
\hline 8 Chapecó - Companhia Industrial de Alimentos & Xaxim & $\mathrm{CP}, \mathrm{SH}$ \\
\hline 9 Agro Avícola Vêneto Ltda & Nova Veneza & $\mathrm{CP}, \mathrm{SH}$ \\
\hline 10 Arfrio S/A - Armazéns Gerais Frigorifico & Itajaí & CS \\
\hline 11 Cooperativa Central Oeste Catarinense Ltda & Quilombo & $\mathrm{CP}, \mathrm{SH}$ \\
\hline 12 Seara Alimentos Ltda & Forquilinha & $\mathrm{CP}, \mathrm{SH}$ \\
\hline 13 Brasfrigo S/A & Itajaí & $\mathrm{CS}$ \\
\hline 14 Seara Alimentos Ltda & Jaraguá do Sul & $\mathrm{CP}, \mathrm{SH}$ \\
\hline 15 Cooperativa Central Oeste Catarinense & Maravilha & $\mathrm{CP}, \mathrm{SH}$ \\
\hline 16 Arfrio S/A - Armazéns Gerais Frigoríficos & $\begin{array}{l}\text { São Francisco do } \\
\text { Sul }\end{array}$ & $\mathrm{CS}$ \\
\hline 17 Macedo Koerich S/A & São José & $\mathrm{CP}, \mathrm{SH}$ \\
\hline 18 Agil Armazéns Gerais Imbituba Ltda & Imbituba & CS \\
\hline $\begin{array}{l}\text { 19 Safrio - Serviço de Armazenagem Frigorificada } \\
\text { Ltda }\end{array}$ & Chapecó & CS \\
\hline \multicolumn{3}{|l|}{ Rio Grande do Sul } \\
\hline 20 Souto Oliveira S/A Indústria de Alimentação & Pelotas & $\mathrm{CS}$ \\
\hline 21 Perdigão Agroindustrial S/A & Serafina Correa & $\mathrm{CP}, \mathrm{SH}$ \\
\hline 22 Penasul Alimentos Ltda & Roca Sales & $\mathrm{CP}, \mathrm{SH}$ \\
\hline 23 Frangosul S/A Agro Avícola Industrial & Caxias do Sul & $\mathrm{CP}, \mathrm{CS}, \mathrm{SH}$ \\
\hline 24 Penasul Alimentos Ltda & Caxias do Sul & $\mathrm{CP}, \mathrm{SH}$ \\
\hline 25 Frangosul S/A Agro Avícola Industrial & Passo Fundo & $\mathrm{CP}, \mathrm{CS}, \mathrm{SH}$ \\
\hline 26 Frigorífico Extremo Sul S/A & Capão do Leão & $\mathrm{CS}$ \\
\hline 27 Companhia Minuano de Alimentos & Lajeado & $\mathrm{CP}, \mathrm{SH}$ \\
\hline 28 Perdigão Agroindustrial S/A & Marau & $\mathrm{CP}, \mathrm{SH}$ \\
\hline 29 Frangosul S/A Agro Avícola Industrial & Montenegro & $\mathrm{CP}, \mathrm{CS}, \mathrm{SH}$ \\
\hline $\begin{array}{l}30 \text { Companhia Nacional de Abastecimento - } \\
\text { CONAB }\end{array}$ & Canoas & $\mathrm{CS}$ \\
\hline 31 Companhia Estadual de Silos e Armazéns - & Capão do Leão & $\mathrm{CS}$ \\
\hline \multicolumn{3}{|l|}{ Paraná } \\
\hline 32 Perdigão Agroindustrial S/A & Carambeí & $\mathrm{CP}, \mathrm{CS}, \mathrm{SH}$ \\
\hline 33 Copacol - Cooperativa Agrícola Consolata Ltda & Cafelândia & $\mathrm{CP}, \mathrm{SH}$ \\
\hline
\end{tabular}


APÊNDICE 2 - Empresas habilitadas a exportar para a União Européia (em vigor a partir de 03/02/2003).

\begin{tabular}{lll}
\hline 34 Dagranja agroindustrial Ltda & Lapa & CP, CS, SH \\
35 Sadia S/A & Toledo & CP, SH \\
36 Sadia S/A & Paranaguá & CS \\
37 Sadia S/A & Paranaguá & CS \\
38 Martini Meat S/A - Armazéns Gerais & Paranaguá & CS \\
39 Granja Rezende S/A & Dois Vizinhos & CP, SH \\
40 Granja Rezende S/A & Francisco Beltrão & CP, SH \\
41 Companhia Produtores de Armazéns Gerais & Paranaguá & CS \\
42 Cooperativa Agrícola Mista Vale do Piquiri Ltda & Palotina & CP, SH \\
43 Cooperativa Agrícola Cascavel Ltda & Cascavel & CP, SH \\
44 Cooperativa Agroindustrial Lar & Matelândia & $\mathrm{CP}, \mathrm{SH}$ \\
São Paulo & & \\
45 Cefri - Estocagem Frigorifica e Agroindústria & Mairinque & $\mathrm{CS}$ \\
Ltda & & \\
46 Refrio - Armazéns Gerais Frigoríficos Ltda & Itapecerica da Serra & $\mathrm{CS}$ \\
47 Brás Export - Comércio, Importação, Exportação & Santos & $\mathrm{CS}$ \\
e Armazéns Gerais Ltda & & \\
48 Osato Alimentos & Monte Alegre do Sul & $\mathrm{CP}, \mathrm{SH}$ \\
49 Avante S/A - Armazéns Gerais Frigoríficos & Santos & $\mathrm{CS}$ \\
50 Air Cold Armazéns Gerais Ltda & Santos & $\mathrm{CS}$ \\
51 Seara Alimentos Ltda & Nuporanga & $\mathrm{CP}, \mathrm{SH}$ \\
52 Localfrio S/A - Armazéns Gerais Frigoríficos & Guarujá & $\mathrm{CS}$ \\
53 Confrio Armazéns Gerais Ltda & Bebedouro & $\mathrm{CS}$ \\
54 Avicultura Granja Céu Azul Ltda & Itapetininga & $\mathrm{CP}, \mathrm{SH}$ \\
55 Arfrio S/A - Armazéns Gerais Frigoríficos & Santos & $\mathrm{CS}$ \\
Minas Gerais & & \\
56 Granja Rezende S/A & Uberlândia & $\mathrm{CP}, \mathrm{SH}$ \\
Goiás & & \\
57 Perdigão Agroindustrial S/A & Rio Verde & $\mathrm{CP}, \mathrm{SH}$ \\
Mato Grosso & & \\
58 Sadia S/A & Várzea Grande & $\mathrm{CP}, \mathrm{SH}$ \\
Mato Grosso do Sul & & \\
59 Frangosul S/A Agro Avícola Industrial & Caarapo & $\mathrm{CP}, \mathrm{SH}$ \\
60 Seara Alimentos Ltda & Sidrolândia & $\mathrm{CP}, \mathrm{SH}$ \\
\hline
\end{tabular}

Fonte: Brasil (2003)

Nota: $\mathrm{CP}=$ cutting plant $\mathrm{CS}=$ cold store $; \mathrm{SH}=$ slaughterhouse . 
APÊNDICE 3 - Empresas avícolas habilitadas para exportar para a UE com abatedouro (em vigor a partir de 03/02/2003).

\begin{tabular}{|c|c|c|}
\hline Santa Catarina & Município & Atividades \\
\hline 1 Sadia S/A & Concórdia & $\mathrm{CP}, \mathrm{SH}$ \\
\hline 2Perdigão Agroinduistrial S/A & Videira & $\mathrm{CP}, \mathrm{SH}$ \\
\hline 3 Sadia S/A & Chapecó & $\mathrm{CP}, \mathrm{SH}$ \\
\hline 4Perdigão Agroindistrial S/A & Capinzal & $\mathrm{CP}, \mathrm{SH}$ \\
\hline 5Seara Alimentos Ltda & Itapiranga & $\mathrm{CP}, \mathrm{SH}$ \\
\hline 6Chapecó - Companhia Industrial de Alimentos & Xaxim & $\mathrm{CP}, \mathrm{SH}$ \\
\hline 7 Agro Avícola Vêneto Ltda & Nova Veneza & $\mathrm{CP}, \mathrm{SH}$ \\
\hline 8 Cooperativa Central Oeste Catarinense Ltda & Quilombo & $\mathrm{CP}, \mathrm{SH}$ \\
\hline 9Seara Alimentos Ltda & Forquilinha & $\mathrm{CP}, \mathrm{SH}$ \\
\hline 10 Seara Alimentos Ltda & Jaraguá do Sul & $\mathrm{CP}, \mathrm{SH}$ \\
\hline 11 Cooperativa Central Oeste Catarinense & Maravilha & CP, SH \\
\hline 12 Macedo Koerich S/A & São José & $\mathrm{CP}, \mathrm{SH}$ \\
\hline \multicolumn{3}{|l|}{ Rio Grande do Sul } \\
\hline 13 Perdigão Agroindustrial S/A & Serafina Correa & $\mathrm{CP}, \mathrm{SH}$ \\
\hline 14 Penasul Alimentos Ltda & Roca Sales & $\mathrm{CP}, \mathrm{SH}$ \\
\hline 15 Frangosul S/A Agro Avícola Industrial & Caxias do Sul & $\mathrm{CP}, \mathrm{CS}, \mathrm{SH}$ \\
\hline 16 Penasul Alimentos Ltda & Caxias do Sul & $\mathrm{CP}, \mathrm{SH}$ \\
\hline 17 Frangosul S/A Agro Avícola Industrial & Passo Fundo & $\mathrm{CP}, \mathrm{CS}, \mathrm{SH}$ \\
\hline 18 Companhia Minuano de Alimentos & Lajeado & $\mathrm{CP}, \mathrm{SH}$ \\
\hline 19Perdigão Agroindustrial S/A & Marau & $\mathrm{CP}, \mathrm{SH}$ \\
\hline 20 Frangosul S/A Agro Avícola Industrial & Montenegro & $\mathrm{CP}, \mathrm{CS}, \mathrm{SH}$ \\
\hline \multicolumn{3}{|l|}{ Paraná } \\
\hline 21 Perdigão Agroindustrial S/A & Carambeí & $\mathrm{CP}, \mathrm{CS}, \mathrm{SH}$ \\
\hline 22 Copacol - Cooperativa Agrícola Consolata Ltda & Cafelândia & $\mathrm{CP}, \mathrm{SH}$ \\
\hline 23 Dagranja agroindustrial Ltda & Lapa & $\mathrm{CP}, \mathrm{CS}, \mathrm{SH}$ \\
\hline 24 Sadia S/A & Toledo & $\mathrm{CP}, \mathrm{SH}$ \\
\hline 25 Granja Rezende S/A & Dois Vizinhos & $\mathrm{CP}, \mathrm{SH}$ \\
\hline 26 Granja Rezende S/A & Francisco Beltrão & $\mathrm{CP}, \mathrm{SH}$ \\
\hline 27 Cooperativa Agrícola Mista Vale do Piquiri Ltda & Palotina & $\mathrm{CP}, \mathrm{SH}$ \\
\hline 28 Cooperativa Agrícola Cascavel Ltda & Cascavel & $\mathrm{CP}, \mathrm{SH}$ \\
\hline 29 Cooperativa Agroindustrial Lar & Matelândia & $\mathrm{CP}, \mathrm{SH}$ \\
\hline \multicolumn{3}{|l|}{ São Paulo } \\
\hline & Monte Alegre do & \\
\hline 30Osato Alin & Sul & $\mathrm{CP}, \mathrm{SH}$ \\
\hline 31 Seara Alimentos Ltda & Nuporanga & $\mathrm{CP}, \mathrm{SH}$ \\
\hline
\end{tabular}


APÊNDICE 3 - Empresas avícolas habilitadas para exportar para a UE com abatedouro (em vigor a partir de 03/02/2003).

\begin{tabular}{lll}
\hline \multicolumn{1}{c}{ 32 Avicultura Granja Céu Azul Ltda } & Itapetininga & $\mathrm{CP}, \mathrm{SH}$ \\
$\begin{array}{l}\text { Minas Gerais } \\
\text { 33 Granja Rezende S/A }\end{array}$ & Uberlândia & $\mathrm{CP}, \mathrm{SH}$ \\
$\begin{array}{l}\text { Goiás } \\
\quad \text { Rio Perdigão Agroindustrial S/A }\end{array}$ & $\mathrm{CP}, \mathrm{SH}$ \\
$\begin{array}{l}\text { Mato Grosso } \\
\text { 35 Sadia S/A }\end{array}$ & Várzea Grande & $\mathrm{CP}, \mathrm{SH}$ \\
$\begin{array}{l}\text { Mato Grosso do Sul } \\
\text { 36 Frangosul S/A Agro Avícola Industrial }\end{array}$ & $\begin{array}{l}\text { Caarapo } \\
\text { 37 Seara Alimentos Ltda }\end{array}$ & $\mathrm{CP}, \mathrm{SH}$ \\
\hline
\end{tabular}

Fonte: Brasil (2003)

Nota: $\mathrm{CP}=$ cutting plant CS = cold store; $\mathrm{SH}=$ slaughterhouse. 
APÊNDICE 4 - Empresas habilitadas para as quais foi enviado o questionário.

1 Sadia S/A

2Perdigão Agroindustrial S/A

3 Chapecó - Companhia Industrial de Alimentos

4 Agro Avícola Vêneto Ltda

5 Cooperativa Central Oeste Catarinense Ltda

6 Seara Alimentos Ltda

7 Macedo Koerich S/A

8Frangosul S/A Agro Avícola Industrial

9Penasul Alimentos Ltda

10 Companhia Minuano de Alimentos

11 Copacol - Cooperativa Agrícola Consolata Ltda

12 Dagranja agroindustrial Ltda

13 Cooperativa Agrícola Mista Vale do Piquiri Ltda

14Cooperativa Agrícola Cascavel Ltda

15 Cooperativa Agroindustrial Lar

16Osato Alimentos

17 Avicultura Granja Céu Azul Ltda

Fonte: Brasil (2003) 
APÊNDICE 5 - Questionário enviado para as empresas avícolas exportadoras.

\section{$\underline{\text { I - Producão }}$}

1) Qual a produção e a exportação (total e para a Europa) da empresa? (preencher os espaços)

\begin{tabular}{|c|c|c|c|}
\hline Ano & $\begin{array}{c}\text { Produção total } \\
\text { US\$ }\end{array}$ & $\begin{array}{c}\text { Exportação total } \\
\text { US\$ }\end{array}$ & $\begin{array}{c}\text { Exportação para Europa (UE) } \\
\text { US\$ }\end{array}$ \\
\hline 1996 & & & \\
\hline 1997 & & & \\
\hline 1998 & & & \\
\hline 1999 & & & \\
\hline 2001 & & & \\
\hline 2002 & & & \\
\hline
\end{tabular}

\section{II - Relacões da empresa com clientes europeus}

2) A empresa tem observado preocupação por parte dos clientes europeus em relação à segurança do alimento?

Considere nível de preocupação de acordo com a escala abaixo:

$0=$ Nenhum nível de preocupação

1= Baixo nível de preocupação

$2=$ Médio nível de preocupação

$3=$ Alto nível de preocupação

4= Altíssimo nível de preocupação

\begin{tabular}{|c|c|c|c|c|c|c|c|}
\hline \multirow[t]{2}{*}{ Clientes } & \multirow{2}{*}{$\begin{array}{l}\text { Tipos de clientes } \\
\text { (rede de supermercados, } \\
\text { rede de restaurantes, } \\
\text { atacadistas, distribuidores, } \\
\text { etc) }\end{array}$} & \multirow[t]{2}{*}{ País } & \multicolumn{5}{|c|}{ Nível de preocupação } \\
\hline & & & 0 & 1 & 2 & 3 & 4 \\
\hline \multicolumn{8}{|l|}{ Cliente A } \\
\hline \multicolumn{8}{|l|}{ Cliente B } \\
\hline \multicolumn{8}{|l|}{ Cliente $\mathrm{C}$} \\
\hline \multicolumn{8}{|l|}{ Cliente D } \\
\hline Cliente E & & & & & & & \\
\hline Cliente F & & & & & & & \\
\hline
\end{tabular}


3) Em relação aos clientes da questão anterior, quais os programas de qualidade que são exigidos que a empresa adote? (marque com um x em cada cliente relacionado na tabela da questão $\mathrm{n}^{\circ}$ ).

\begin{tabular}{|l|l|l|l|l|l|l|}
\hline \multirow{2}{*}{ Programas de qualidade } & \multicolumn{5}{|c|}{ Cliente } \\
\hline & A & B & C & D & E & F \\
\hline Nenhum & & & & & & \\
\hline Análise de Riscos e Pontos Críticos de Controle (HACCP) & & & & & & \\
\hline Boas Práticas de Fabricação (BPF) & & & & & & \\
\hline $\begin{array}{l}\text { Procedimento Padrão de Sanitização e Higiene Operacional } \\
\text { (SSOP) }\end{array}$ & & & & & & \\
\hline ISO 9000 & & & & & & \\
\hline Rastreabilidade é exigida em: & & & & & & \\
\hline Em todas as fases de criação animal & & & & & & \\
\hline Na produção de rações & & & & & & \\
\hline No abate & & & & & & \\
\hline No processamento & & & & & & \\
\hline Não exige rastreabilidade & & & & & & \\
\hline Outros (listar) & & & & & & \\
\hline
\end{tabular}

4) Quais são as principais exigências dos clientes europeus em relação a matéria-prima? (marque com um $x$ em cada cliente relacionado na tabela da questão $\mathrm{n}^{\circ} 2$ ).

\begin{tabular}{|l|l|l|l|l|l|l|}
\hline \multicolumn{1}{|c|}{ Exigências dos clientes } & \multicolumn{5}{c|}{ Clientes } \\
\cline { 2 - 7 } & A & B & C & D & E & F \\
\hline Não usar grãos geneticamente modificados & & & & & & \\
\hline Não usar ingredientes de origem animal & & & & & & \\
\hline Não usar promotores de crescimento & & & & & & \\
\hline Não usar aditivos alimentares & & & & & & \\
\hline Não usar antibióticos & & & & & & \\
\hline Outro: & & & & & & \\
\hline Outro: & & & & & & \\
\hline
\end{tabular}

5) Qual a opinião da empresa no que se refere a estas exigências (citadas nas questões 3 e 4 ) dos clientes europeus?

\begin{tabular}{|l|c|c|}
\hline \multicolumn{1}{|c|}{ Alternativas } & \multicolumn{2}{c|}{$\begin{array}{c}\text { Marque com } \\
\text { um X }\end{array}$} \\
\cline { 2 - 3 } & SIM & NÃO \\
\hline Estas exigências retratam a opinião e preocupações dos consumidores & & \\
\hline Estas exigências representam barreiras não-tarifárias & & \\
\hline $\begin{array}{l}\text { Estas exigências precisam ser cumpridas para permanecer no mercado } \\
\text { europeu }\end{array}$ & & \\
\hline Outros & & \\
\hline Nada a declarar & & \\
\hline
\end{tabular}


6) Quais são as principais medidas adotadas pela empresa para atender seus respectivos clientes? (marque com um x em cada cliente relacionado na tabela da questão $\mathrm{n}^{\circ} 2$ ).

\begin{tabular}{|l|c|c|c|c|c|c|}
\hline \multicolumn{1}{|c|}{ Medidas adotadas } & \multicolumn{5}{c|}{ Clientes } \\
\cline { 2 - 7 } & A & B & C & D & E & F \\
\hline $\begin{array}{l}\text { Assegurar-se das fontes de fornecimento da matéria- } \\
\text { prima }\end{array}$ & & & & & & \\
\hline Investir em pesquisa e tecnologia & & & & & & \\
\hline Contratar mão-de-obra especializada & & & & & & \\
\hline Passou a implantar sistema de rastreabilidade & & & & & & \\
\hline Passou a implantar programas de qualidade & & & & & & \\
\hline Não adotou nenhuma medida & & & & & & \\
\hline Outras (listar): & & & & & & \\
\hline
\end{tabular}

7) Quais as principais demandas da empresa em relação à atuação do setor público na solução das exigências dos clientes europeus?

\begin{tabular}{|l|l|}
\hline \multicolumn{1}{|c|}{ Alternativas } & Marque com um X \\
\hline Nada a declarar & \\
\hline Emissão de selos de qualidade & \\
\hline Laboratórios de análise de resíduos & \\
\hline Pesquisas para confrontar os resultados europeus & \\
\hline Outros. Quais? & \\
\hline
\end{tabular}

\section{III - Relacões da empresa com fornecedores de matérias-prima}

8) Como a empresa adquiria matéria-prima frango antes do aparecimento do mal da vaca louca (1996)?

\begin{tabular}{|l|c|}
\hline \multicolumn{1}{|c|}{ Alternativas } & $\begin{array}{c}\text { Marque com } \\
\text { um X }\end{array}$ \\
\hline Via compra no mercado & \\
\hline Via contratos: & \\
\hline Integrado & \\
\hline Meeiro & \\
\hline Outro. Qual? & \\
\hline Outro. Qual? & \\
\hline
\end{tabular}

9) Como a empresa adquire matéria-prima frango atualmente?

\begin{tabular}{|l|c|}
\hline \multicolumn{1}{|c|}{ Alternativas } & $\begin{array}{c}\text { Marque com } \\
\text { um X }\end{array}$ \\
\hline Nada mudou & \\
\hline Via compra no mercado & \\
\hline Via contratos: & \\
\hline Integrado & \\
\hline Meeiro & \\
\hline Outro. Qual? & \\
\hline
\end{tabular}


Outro. Qual ?

10) Como era o relacionamento com o fornecedor de grãos antes do aparecimento do mal da vaca louca (1996)?

\begin{tabular}{|l|l|}
\hline \multicolumn{1}{|c|}{ Alternativas } & Marque com um X \\
\hline Via compra no mercado & \\
\hline Via contratos: & \\
\hline Integrado & \\
\hline Meeiro & \\
\hline Outro. Qual? & \\
\hline Outro. Qual? & \\
\hline
\end{tabular}

11) Como é o relacionamento com o fornecedor de grãos atualmente?

\begin{tabular}{|l|l|}
\hline \multicolumn{1}{|c|}{ Alternativas } & Marque com um X \\
\hline Nada mudou & \\
\hline Via compra no mercado & \\
\hline Via contratos formais como: & \\
\hline Integrado & \\
\hline Meeiro & \\
\hline Outro. Qual? & \\
\hline
\end{tabular}

\section{IV-Relacões da empresa com fornecedores de premix}

12) Como era o relacionamento com o fornecedor de premix antes do aparecimento do mal da vaca louca (1996)?

\begin{tabular}{|l|l|}
\hline \multicolumn{1}{|c|}{ Alternativas } & Preencha em porcentagem \\
\hline Via compra no mercado & \\
\hline Via contratos (explicar:) & \\
\hline & \\
\hline & \\
\hline Outro. Qual? & \\
\hline Produz seu próprio premix & \\
\hline Outro. Qual? & \\
\hline
\end{tabular}

13) Como a empresa adquire o premix atualmente?

\begin{tabular}{|l|l|}
\hline \multicolumn{1}{|c|}{ Alternativas } & $\begin{array}{c}\text { Preencha em } \\
\text { porcentagem(\%) }\end{array}$ \\
\hline Nada mudou & \\
\hline Via compra no mercado & \\
\hline Via contratos (explicar:) & \\
\hline & \\
\hline \multicolumn{1}{|c|}{ Outro. Qual? } & \\
\hline Produz seu próprio premix & \\
\hline Outro. Qual? & \\
\hline
\end{tabular}


APÊNDICE 6 - Roteiro dos estudos de caso.

\section{I - Producão}

1) Desde quando a empresa exporta para a União Européia?

2) Qual a ordem de importância da UE na lista dos clientes?

3) Por que a empresa optou para exportar a este mercado?

4) A produção exportada para a UE no período de 1996-2002 em US\$.

\section{II - Relacões da empresa com clientes europeus}

5) Explique a função do cliente europeu com o qual sua empresa trabalha (processador, distribuidor, trader).

6) Desde quando o cliente passou a exigir que a empresa implantasse programas de qualidade?

7) Desde que ano implantou o Programa EFSIS ? Se não implantou, ainda não foi exigido?

8) Como é o sistema de rastreabilidade implantado? (por lote, por origem, por data de abate, por tipo de destino de cliente, etc.)

9) Além das exigências (GGM; subprodutos de origem animal; aditivos, antibióticos; promotores de crescimento) existem outras que os clientes europeus passarão a exigir em breve?

10) Em relação às medidas que a empresa adotou para atender os clientes, elas foram adotadas somente para atender a solicitação dos clientes europeus ou também para atender outros clientes?

11) Existem outras medidas importantes que a empresa adotou para satisfazer os clientes no que diz respeito à segurança dos alimentos fabricados ?

12) A análise das especificidades do frango (inteiro e em cortes) exportado é realizada na UE? A empresa acha que esta análise deveria ser feito no Brasil, sob a supervisão do MAPA ou em laboratórios credenciados do MAPA?

\section{III - Relacões da empresa com fornecedores de matérias-prima}

13) Como era a relação contratual entre a empresa e o fornecedor de grãos antes de 1996 (mal da vaca louca) e como é atualmente? 
14) Quais as medidas adotadas pela empresa quando o governo decretou a liberalização da safra de grãos transgênicos 2002/03 no Brasil (porque a UE proíbe seu uso na ração)?

\section{IV-Relações da empresa com fornecedores de premix}

15) Como era a relação contratual entre a empresa e o fornecedor de premix antes de 1996 (mal da vaca louca) e como é atualmente? 
APÊNDICE 7 - Dados de produção, exportações total e para a UE no período de 19962002.

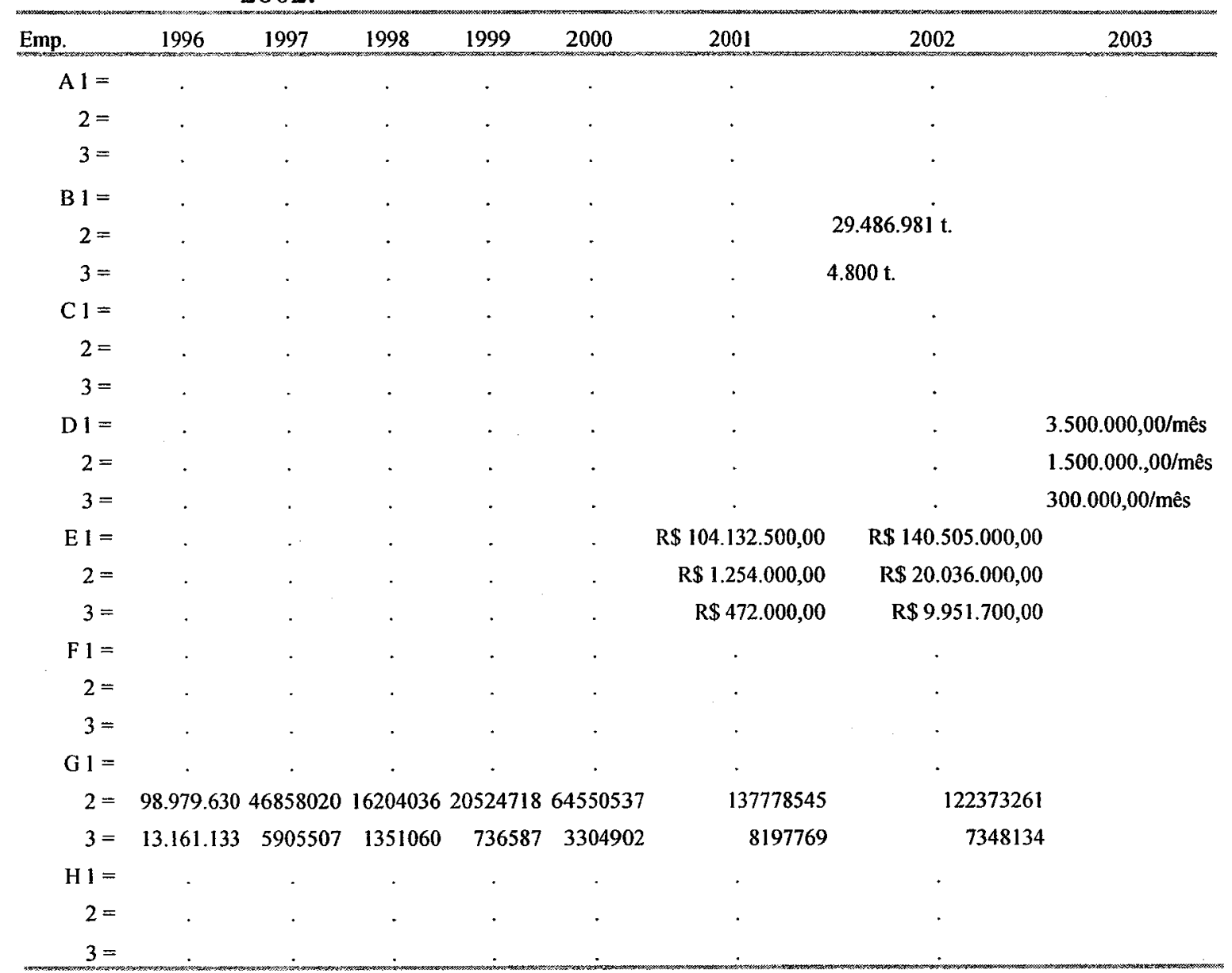

Fonte: Dados da pesquisa.

Nota: o ponto (.) representa a falta de resposta.

Legenda: 1 = Produção total; 2 = Exportação total em US\$; 3 = Exportação para a UE em US\$. 
APÊNDICE 8 - Empresas individuais - cliente, país, nível de preocupação e programas de qualidade.

\begin{tabular}{|c|c|c|c|c|c|c|c|c|c|c|c|c|c|c|}
\hline \multicolumn{3}{|c|}{ empresas cliente país } & \multirow[t]{2}{*}{ preoc } & \multicolumn{11}{|c|}{ programas } \\
\hline & & & & 0 & 1 & 2 & 3 & 4 & 4 & 6 & 7 & 8 & 9 & 10 \\
\hline \multirow[t]{4}{*}{$\mathrm{A}$} & 1 & & 4 & & $\mathrm{x}$ & $\mathrm{x}$ & $\mathrm{x}$ & & $\mathrm{x}$ & $\mathrm{x}$ & $\mathrm{x}$ & $\mathrm{x}$ & & \\
\hline & 2 & & 3 & & $\mathrm{x}$ & $\mathrm{x}$ & $\mathrm{x}$ & & $\mathrm{x}$ & $\mathrm{x}$ & $\mathrm{x}$ & $\mathrm{x}$ & & \\
\hline & 6 & & 4 & & $\mathrm{x}$ & $\mathrm{x}$ & $\mathrm{x}$ & & $\mathrm{x}$ & $\mathrm{x}$ & $\mathrm{x}$ & $\mathrm{x}$ & & \\
\hline & 5 & & 4 & & $\mathrm{x}$ & $\mathrm{x}$ & $\mathrm{x}$ & & $\mathrm{x}$ & $\mathrm{x}$ & $\mathrm{x}$ & $\mathrm{x}$ & & \\
\hline \multirow[t]{5}{*}{ B } & 2 & 1 & 4 & & $\mathrm{x}$ & $\mathrm{x}$ & $\mathrm{x}$ & & & & & & $\mathrm{x}$ & \\
\hline & 3 & 1 & 4 & & $\mathrm{x}$ & $\mathrm{x}$ & $\mathrm{x}$ & & & & & & $\mathrm{x}$ & \\
\hline & 2 & 2 & 4 & & $\mathrm{x}$ & $\mathrm{x}$ & $\mathrm{x}$ & & & & & & $\mathrm{x}$ & \\
\hline & 3 & 2 & 4 & & $\mathrm{x}$ & $\mathrm{x}$ & $\mathrm{x}$ & & & & & & $\mathrm{x}$ & \\
\hline & 2 & 3 & 4 & & $\mathrm{x}$ & $\mathrm{x}$ & $\mathrm{x}$ & & & & & & $\mathrm{x}$ & \\
\hline \multirow[t]{6}{*}{$\mathrm{C}$} & 4 & 3 & 4 & & $\mathrm{x}$ & $\mathrm{X}$ & $\mathrm{x}$ & & $\mathrm{x}$ & $\mathrm{x}$ & $\mathrm{x}$ & $\mathrm{x}$ & & $\mathrm{X}$ \\
\hline & 2 & 1 & 3 & & $\mathrm{x}$ & $\mathrm{X}$ & $\mathrm{x}$ & & $\mathrm{x}$ & $\mathrm{x}$ & $\mathrm{x}$ & $\mathrm{x}$ & & \\
\hline & 4 & 3 & 3 & & $\mathrm{x}$ & $\mathrm{X}$ & $\mathrm{x}$ & & $\mathrm{x}$ & $\mathrm{x}$ & $\mathrm{x}$ & $\mathrm{x}$ & & $\mathrm{X}$ \\
\hline & 2 & 5 & 4 & & $\mathrm{x}$ & $\mathrm{X}$ & $\mathrm{x}$ & $\mathrm{x}$ & $\mathrm{x}$ & $\mathrm{x}$ & $\mathrm{x}$ & $\mathrm{x}$ & & $\mathrm{X}$ \\
\hline & 4 & 3 & 4 & & $\mathrm{x}$ & $\mathrm{X}$ & $\mathrm{x}$ & & $\mathrm{x}$ & $\mathrm{x}$ & $\mathrm{x}$ & $\mathrm{x}$ & & $\mathrm{X}$ \\
\hline & 4 & 1 & 4 & & $\mathrm{x}$ & $\mathrm{x}$ & $\mathrm{x}$ & & $\mathrm{x}$ & $\mathrm{x}$ & $\mathrm{x}$ & $\mathrm{x}$ & & \\
\hline \multirow[t]{4}{*}{ D } & 2 & 1 & 4 & & $\mathrm{x}$ & $\mathrm{x}$ & $\mathrm{x}$ & & & $\mathrm{x}$ & & & & \\
\hline & 2 & 11 & 4 & & & $\mathrm{x}$ & $x$ & & & $\mathrm{x}$ & & & & \\
\hline & 2 & 2 & 4 & & & $\mathrm{x}$ & $\mathrm{x}$ & & & $\mathrm{x}$ & & & & \\
\hline & 2 & 6 & 4 & & $\mathrm{x}$ & $\mathrm{x}$ & $\mathrm{x}$ & & & $\mathrm{x}$ & & & & \\
\hline \multirow[t]{4}{*}{$\mathrm{E}$} & 3 & 2 & 1 & & $\mathrm{x}$ & & $\mathrm{x}$ & & & & & & $\mathrm{x}$ & \\
\hline & 4 & 3 & 3 & & $\mathrm{x}$ & $\mathrm{x}$ & $\mathrm{x}$ & & $\mathrm{x}$ & $\mathrm{x}$ & $\mathrm{x}$ & $\mathrm{x}$ & & \\
\hline & 4 & 5 & 3 & & $\mathrm{x}$ & $\mathrm{x}$ & $\mathrm{x}$ & & & & & & & \\
\hline & 3 & 4 & 1 & $\mathrm{x}$ & & & & & & & & & & \\
\hline \multirow[t]{6}{*}{$\mathrm{F}$} & 2 & 3 & 4 & & $\mathrm{x}$ & & $x$ & & $\mathrm{x}$ & & & & & \\
\hline & 2 & 8 & 2 & & $\mathrm{x}$ & & $\mathrm{x}$ & & $\mathrm{x}$ & & & & & \\
\hline & 2 & 9 & 2 & & $\mathrm{x}$ & & $\mathrm{x}$ & & $\mathrm{x}$ & & & & & \\
\hline & 2 & 7 & 3 & & $\mathrm{x}$ & & $\mathrm{x}$ & & $\mathrm{x}$ & & & & & \\
\hline & 2 & 1 & 3 & & $\mathrm{x}$ & & $\mathrm{x}$ & & $x$ & & & & & \\
\hline & 2 & 2 & 3 & & $\mathrm{x}$ & & $\mathrm{x}$ & & $x$ & & & & & \\
\hline \multirow[t]{6}{*}{ G } & 7 & 3 & 4 & & $\mathrm{x}$ & $\mathbf{x}$ & $\mathrm{x}$ & & $\mathrm{x}$ & & & & & \\
\hline & 7 & 2 & 4 & & $\mathrm{x}$ & $x$ & $\mathrm{x}$ & & $\mathrm{x}$ & & & & & \\
\hline & 7 & 1 & 4 & & $\mathrm{x}$ & $x$ & $x$ & & $\mathrm{x}$ & & & & & \\
\hline & 3 & & 4 & & $\mathrm{x}$ & $x$ & & & & & $x$ & & & \\
\hline & 2 & & 4 & & $\mathrm{x}$ & $x$ & & & & & $\mathrm{x}$ & & & \\
\hline & 8 & & 4 & & $\mathrm{x}$ & $x$ & & & & & & & $\mathrm{x}$ & \\
\hline $\mathrm{H}$ & 9 & 3 & 3 & & $x$ & $\mathrm{x}$ & $\mathbf{x}$ & & $\mathrm{x}$ & $\mathrm{X}$ & $\mathbf{x}$ & $\mathrm{x}$ & & \\
\hline
\end{tabular}


APÊNDICE 8 - Empresas individuais - cliente, país, nível de preocupação e programas de qualidade.

\begin{tabular}{cccccccccc}
\hline 9 & 11 & 4 & $\mathrm{x}$ & $\mathrm{x}$ & $\mathrm{x}$ & $\mathrm{x}$ & $\mathrm{x}$ & $\mathrm{x}$ & $\mathrm{x}$ \\
9 & 1 & 3 & $\mathrm{x}$ & $\mathrm{x}$ & $\mathrm{x}$ & $\mathrm{x}$ & $\mathrm{x}$ & $\mathrm{x}$ & $\mathrm{x}$ \\
9 & 2 & 3 & $\mathrm{x}$ & $\mathrm{x}$ & $\mathrm{x}$ & $\mathrm{x}$ & $\mathrm{x}$ & $\mathrm{x}$ & $\mathrm{x}$ \\
9 & 6 & 3 & $\mathrm{x}$ & $\mathrm{x}$ & $\mathrm{x}$ & $\mathrm{x}$ & $\mathrm{x}$ & $\mathrm{x}$ & $\mathrm{x}$ \\
9 & 10 & 2 & & $\mathrm{x}$ & $\mathrm{x}$ & & & $\mathrm{x}$ & $\mathrm{x}$ \\
\hline
\end{tabular}

Fonte: Dados da pesquisa.

Legenda: $1=$ =indústria; 2 =distribuidor; $3=$ =atacadista; 4 -processador; $5=$ supermercado, $6=$ restaurante, $7=$ traders, $8=$ outro e $9=$ geral;

1=Alemanha; 2=Holanda; 3=Reino Unido; 4=Itália; 5=França; 6=Espanha;

7=Portugal; 8=Romênia; 9=Bulgária;10= Rússia; 11=Suíça;

$0=$ nenhum nível de preocupação; $1=$ baixo nível de preocupação; $2=$ =médio nível de preocupação; 3=alto nível de preocupação; 4=altíssimo nível de preocupação;

0=nenhum; 1=Análise de Riscos e Pontos Críticos de Controle (HACCP);

2= Boas Práticas de Fabricação (BPF); 3=Procedimento Padrão de Sanitização e Higiene Operacional (SSOP); 4=ISO 9000; 5=rastreabilidade em todas as fases de criação animal; 6=na produção de rações; 7-no abate; $8=$ no processamento; $9=$ não exige rastreabilidade e $10=$ outro. 
APÊNDICE 9 - Tipos de clientes e o respectivo nível de preocupação.

\begin{tabular}{|c|c|}
\hline tipo de cliente & nível de preocupação \\
\hline Indústria & 4 \\
\hline Distribuidor & 3 \\
\hline Distribuidor & 4 \\
\hline Distribuidor & 4 \\
\hline Distribuidor & 2 \\
\hline Distribuidor & 2 \\
\hline Distribuidor & 4 \\
\hline Distribuidor & 4 \\
\hline Distribuidor & 4 \\
\hline Distribuidor & 3 \\
\hline Distribuidor & 4 \\
\hline Distribuidor & 4 \\
\hline Distribuidor & 4 \\
\hline Distribuidor & 4 \\
\hline Distribuidor & 3 \\
\hline Distribuidor & 3 \\
\hline Distribuidor & 3 \\
\hline Distribuidor & 4 \\
\hline Atacadista & 4 \\
\hline Atacadista & 4 \\
\hline Atacadista & 1 \\
\hline Atacadista & 1 \\
\hline Atacadista & 4 \\
\hline Processador & 4 \\
\hline Processador & 3 \\
\hline Processador & 3 \\
\hline Processador & 4 \\
\hline Processador & 4 \\
\hline Processador & 3 \\
\hline Supermercado & 4 \\
\hline Restaurante & 4 \\
\hline Trader & 4 \\
\hline Trader & 4 \\
\hline Trader & 4 \\
\hline Geral & 4 \\
\hline Geral & 3 \\
\hline Geral & 3 \\
\hline Geral & 3 \\
\hline Geral & 4 \\
\hline Geral & 2 \\
\hline Geral & 3 \\
\hline
\end{tabular}

Fonte: Dados da pesquisa. 
APÊNDICE 10 - Países da UE com seus respectivos clientes.

\begin{tabular}{|c|c|}
\hline País & tipos de clientes \\
\hline Alemanha & Distribuidor \\
\hline Alemanha & Atacadista \\
\hline Alemanha & Distribuidor \\
\hline Alemanha & Processador \\
\hline Alemanha & Distribuidor \\
\hline Alemanha & Distribuidor \\
\hline Alemanha & Trader \\
\hline Alemanha & Geral \\
\hline Holanda & Distribuidor \\
\hline Holanda & Atacadista \\
\hline Holanda & Distribuidor \\
\hline Holanda & Atacadista \\
\hline Holanda & Distribuidor \\
\hline Holanda & Trader \\
\hline Holanda & Geral \\
\hline Reino Unido & Distribuidor \\
\hline Reino Unido & Processador \\
\hline Reino Unido & Distribuidor \\
\hline Reino Unido & Trader \\
\hline Reino Unido & Geral \\
\hline Reino Unido & Processador \\
\hline Reino Unido & Processador \\
\hline Reino Unido & Processador \\
\hline Itália & Atacadista \\
\hline França & Distribuidor \\
\hline França & Processador \\
\hline Espanha & Distribuidor \\
\hline Portugal & Geral \\
\hline Portugal & Distribuidor \\
\hline Romênia & Distribuidor \\
\hline Bulgária & Distribuidor \\
\hline Rússia & Geral \\
\hline Suíça & -Geral \\
\hline Suíça & Distribuidor \\
\hline . & Indústria \\
\hline . & Distribuidor \\
\hline . & Restaurante \\
\hline$\cdot$ & Supermercado \\
\hline . & Atacadista \\
\hline$\cdot$ & Distribuidor \\
\hline & Geral \\
\hline
\end{tabular}

Fonte: Dados da pesquisa.

Nota: (.) quer dizer que o país não foi informado. 
APÊNDICE 11 - Clientes, exigências e medidas adotadas pela empresa.

\begin{tabular}{|c|c|c|c|c|c|c|c|c|c|c|c|c|}
\hline \multicolumn{10}{|c|}{ Empresa client } & & & \\
\hline \multirow{5}{*}{ A } & & 1 & 2 & 3 & 4 & 5 & 6 & 1 & 2 & 3 & 4 & 5 \\
\hline & 1 & $x$ & X & $\mathrm{x}$ & $\mathrm{x}$ & $x$ & & $\mathrm{x}$ & $x$ & X & $x$ & $x$ \\
\hline & 2 & & $\mathrm{X}$ & & $\mathrm{x}$ & $\mathrm{x}$ & & $\mathrm{X}$ & $x$ & $\mathrm{X}$ & $\mathrm{x}$ & $\mathbf{x}$ \\
\hline & 6 & $\mathrm{x}$ & $X$ & $x$ & $\mathrm{x}$ & $x$ & & $x$ & $x$ & X & $\mathbf{x}$ & $x$ \\
\hline & 5 & & $\mathbf{x}$ & $x$ & $\mathrm{x}$ & $x$ & & $x$ & $\mathrm{x}$ & $x$ & $x$ & $x$ \\
\hline \multirow[t]{5}{*}{ B } & 2 & $\mathrm{x}$ & $\mathrm{x}$ & $x$ & $\mathrm{x}$ & $\mathrm{x}$ & & $x$ & $x$ & $x$ & & $x$ \\
\hline & 3 & $\mathrm{x}$ & $\mathbf{x}$ & $\mathrm{x}$ & $\mathrm{x}$ & $\mathrm{x}$ & & $\mathrm{x}$ & $\mathrm{x}$ & $\mathrm{x}$ & & $x$ \\
\hline & 2 & $\mathrm{x}$ & $\mathrm{x}$ & $\mathrm{x}$ & $\mathrm{x}$ & $\mathrm{x}$ & & $\mathrm{x}$ & $\mathrm{x}$ & $\mathrm{x}$ & & $\mathrm{x}$ \\
\hline & 3 & $\mathrm{x}$ & $\mathrm{x}$ & $\mathrm{x}$ & $\mathrm{x}$ & $\mathrm{x}$ & & $\mathrm{x}$ & $\mathrm{x}$ & $\mathrm{x}$ & & $\mathrm{x}$ \\
\hline & 2 & $\mathrm{x}$ & $\mathrm{x}$ & $\mathrm{x}$ & $\mathrm{x}$ & $\mathrm{x}$ & & $\mathrm{x}$ & $\mathrm{x}$ & $\mathrm{x}$ & & $\mathrm{x}$ \\
\hline \multirow[t]{6}{*}{$\mathrm{C}$} & 4 & $\mathrm{x}$ & $\mathrm{x}$ & $x$ & $\mathbf{x}$ & $\mathrm{x}$ & & $\mathrm{x}$ & $\mathbf{x}$ & $\mathrm{x}$ & $\mathrm{x}$ & $\mathrm{x}$ \\
\hline & 2 & $\mathrm{x}$ & $\mathrm{x}$ & & $\mathrm{x}$ & $\mathrm{x}$ & & $\mathrm{x}$ & & & $\mathbf{x}$ & $\mathrm{x}$ \\
\hline & 4 & $\mathrm{x}$ & $\mathrm{x}$ & & $\mathrm{x}$ & $\mathrm{x}$ & & $\mathrm{x}$ & & & $\mathrm{x}$ & $\mathrm{x}$ \\
\hline & 2 & $\mathrm{x}$ & $\mathrm{x}$ & $\mathrm{x}$ & $\mathrm{x}$ & $\mathrm{x}$ & & $\mathrm{x}$ & & & $\mathrm{x}$ & $\mathrm{x}$ \\
\hline & 4 & $\mathrm{x}$ & $\mathrm{x}$ & $\mathrm{x}$ & $\mathrm{x}$ & $\mathrm{x}$ & & $\mathrm{x}$ & $\mathrm{x}$ & $\mathrm{x}$ & $\mathrm{x}$ & $\mathrm{x}$ \\
\hline & 4 & $\mathrm{x}$ & $\mathrm{x}$ & $\mathrm{x}$ & $\mathrm{x}$ & $\mathrm{x}$ & & $\mathrm{x}$ & $\mathrm{x}$ & $\mathrm{x}$ & $\mathbf{x}$ & $\mathrm{x}$ \\
\hline \multirow[t]{4}{*}{ D } & 2 & & & & & & $\mathrm{x}$ & $\mathrm{x}$ & $\mathrm{x}$ & & $\mathrm{x}$ & $\mathrm{x}$ \\
\hline & 2 & & & & & & $\mathrm{x}$ & $\mathrm{x}$ & $\mathrm{x}$ & & $x$ & $x$ \\
\hline & 2 & & & & & & $x$ & $\mathrm{x}$ & $x$ & & $x$ & $\mathrm{x}$ \\
\hline & 2 & & & & & & $x$ & $\mathrm{x}$ & $\mathrm{x}$ & & $x$ & $\mathrm{x}$ \\
\hline \multirow[t]{4}{*}{$\mathrm{E}$} & 3 & & $x$ & & & & & $x$ & $x$ & & $x$ & $x$ \\
\hline & 4 & $x$ & $x$ & $x$ & & & & $x$ & $x$ & $x$ & $x$ & $x$ \\
\hline & 4 & & $\mathrm{x}$ & $x$ & & & & $x$ & $x$ & & $x$ & $x$ \\
\hline & 3 & & $x$ & & & & & $x$ & $\mathrm{x}$ & & $x$ & $x$ \\
\hline \multirow[t]{6}{*}{$\mathrm{F}$} & 2 & . & . & . & . & . & . & & & & $x$ & $x$ \\
\hline & 2 & . & . & . & . & . & . & & & & & \\
\hline & 2 & . & . & . & . & . & . & & & & & \\
\hline & 2 & . & . & . & . & . & . & & & & & \\
\hline & 2 & . & . & . & . & $\cdot$ & . & & & & & \\
\hline & 2 & . & . & . & . & . & . & & & & & \\
\hline \multirow[t]{6}{*}{ G } & 7 & & & $x$ & $x$ & & $\mathrm{x}$ & $\mathrm{x}$ & & & $\mathrm{x}$ & $\mathbf{x}$ \\
\hline & 7 & & & $x$ & $\mathrm{x}$ & & $\mathbf{x}$ & $x$ & & & $\dot{x}$ & $\mathbf{x}$ \\
\hline & 7 & & & $x$ & $\mathrm{x}$ & & $x$ & $\mathrm{x}$ & & & $\mathrm{x}$ & $\mathrm{x}$ \\
\hline & 3 & & & $x$ & $x$ & & $x$ & $\mathrm{x}$ & & & $\mathrm{x}$ & $\mathrm{x}$ \\
\hline & 2 & & & $x$ & $\mathbf{x}$ & & $x$ & $x$ & & & $\mathrm{x}$ & $\mathrm{x}$ \\
\hline & 8 & & & $x$ & $\mathrm{x}$ & & $\mathrm{x}$ & $x$ & & & $x$ & $x$ \\
\hline \multirow[t]{2}{*}{$\mathrm{H}$} & 9 & $x$ & $x$ & $x$ & & & & $\mathrm{x}$ & & $\mathrm{x}$ & $x$ & $\mathrm{x}$ \\
\hline & 9 & $\mathrm{x}$ & $\mathrm{x}$ & $\mathrm{x}$ & & $\mathbf{x}$ & & $\mathrm{x}$ & & $\mathrm{x}$ & $\mathbf{x}$ & $\mathrm{x}$ \\
\hline
\end{tabular}


APÊNDICE 11 - Clientes, exigências e medidas adotadas pela empresa.

\begin{tabular}{lllllll}
9 & $\mathrm{x}$ & $\mathrm{x}$ & $\mathrm{x}$ & $\mathrm{x}$ & $\mathrm{x}$ & $\mathrm{X}$ \\
9 & $\mathrm{x}$ & $\mathrm{x}$ & $\mathrm{x}$ & $\mathrm{x}$ & $\mathrm{x}$ & $\mathrm{x}$ \\
9 & & $\mathrm{x}$ & $\mathrm{x}$ & $\mathrm{x}$ & $\mathrm{x}$ & $\mathrm{x}$ \\
9 & & & $\mathrm{x}$ & $\mathrm{x}$ & $\mathrm{x}$ & \\
\hline
\end{tabular}

Fonte: Dados da pesquisa.

Legenda: 1=não usar grãos geneticamente modificados; 2=não usar ingredientes de origem animal; 3=não usar promotores de crescimento; 4=não usar aditivos alimentares; 5=não usar antibióticos e 6=0utra;

$1=$ assegurar-se das fontes de fornecimentos de matérias-primas; $2=$ investir em pesquisa e tecnologia; $3=$ contratar mão-de-obra especializada; $4=$-passou a implantar sistema de rastreabilidade; 5=passou a implantar programas de qualidade; $6=$ não adotou nenhuma medida e $7=$ outro. 